\title{
The interstitium in myocardial infarction and hypertrophy : experimental and clinical observations
}

Citation for published version (APA):

Willems, I. E. M. G. (1995). The interstitium in myocardial infarction and hypertrophy : experimental and clinical observations. [Doctoral Thesis, Maastricht University]. Rijksuniversiteit Limburg. https://doi.org/10.26481/dis.19951013iw

Document status and date:

Published: 01/01/1995

DOI:

10.26481/dis.19951013iw

Document Version:

Publisher's PDF, also known as Version of record

\section{Please check the document version of this publication:}

- A submitted manuscript is the version of the article upon submission and before peer-review. There can be important differences between the submitted version and the official published version of record.

People interested in the research are advised to contact the author for the final version of the publication, or visit the DOI to the publisher's website.

- The final author version and the galley proof are versions of the publication after peer review.

- The final published version features the final layout of the paper including the volume, issue and page numbers.

Link to publication

\footnotetext{
General rights rights.

- You may freely distribute the URL identifying the publication in the public portal. please follow below link for the End User Agreement:

www.umlib.nl/taverne-license

Take down policy

If you believe that this document breaches copyright please contact us at:

repository@maastrichtuniversity.nl

providing details and we will investigate your claim.
}

Copyright and moral rights for the publications made accessible in the public portal are retained by the authors and/or other copyright owners and it is a condition of accessing publications that users recognise and abide by the legal requirements associated with these

- Users may download and print one copy of any publication from the public portal for the purpose of private study or research.

- You may not further distribute the material or use it for any profit-making activity or commercial gain

If the publication is distributed under the terms of Article $25 \mathrm{fa}$ of the Dutch Copyright Act, indicated by the "Taverne" license above, 
THE INTERSTITIUM IN MYOCARDIAL INFARCTION AND HYPERTROPHY

experimental and clinical observations 
Cover: diagonal photomicrograph: human myocardium, 2-7 days postinfarction, immunohistochemically stained with anti- $\alpha$ smooth muscle actin (ASMA) antibody. Spindle shaped cells, expressing ASMA (brown) are present in the granulation tissue. Horizontal photomicrograph: normal human myocardium, immunohistochemically stained with anti-ASMA antibody. Only smooth muscle cells in the vesselwalls show expression of ASMA. 


\section{THE INTERSTITIUM IN MYOCARDIAL INFARCTION AND HYPERTROPHY}

experimental and clinical observations

\section{PROEFSCHRIFT}

ter verkrijging van de graad van doctor aan de Rijksuniversiteit Limburg te Maastricht, op gezag van de Rector Magnificus, Prof.mr. M.J. Cohen, volgens het besluit van het College van Dekanen, in het openbaar te verdedigen op vrijdag 13 oktober 1995 om 14.00 uur

door

\section{Ingrid E. M. G. Willems}

geboren te Brunssum 
Promotor

Prof.dr. J.W. Arends

\section{Co-promotor}

Dr. M.J.A.P. Daemen

\section{Beoordelingscommissie}

Prof.dr. J.F.M. Smits, voorzitter

Prof.dr. A.E. Becker (Academisch Ziekenhuis Amsterdam)

Prof.dr. M. Borgers

Prof.dr. G. Gabbiani (Universitê de Genève, Zwitserland)

Prof.dr. H.J.J. Wellens

Financial support by the Dutch Heart Foundation for the publication of this thesis is gratefully acknowledged.

For financial support for this thesis we also thank:

Stichting Klinische Pathologie Zuid-Limburg 
Experience does not even err, it is only your judgment that errs in promising itself results which are not caused by your experiments.

Leonardo Da Vinci (c. 1510). 


\section{ACKNOWLEDGEMENTS}

The present thesis would not be completed without the work of the members of the departments of Pathology and Pharmacology at the University of Limburg in Maastricht.

A special word of thanks is directed to Dr, M.J.A.P. Daemen for his never ending forbearance in guiding me through science, and prof.dr. J.W. Arends for his interest and critical remarks during the preparation of the manuscript.

I also would like to thank Prof.dr. J.F.M. Smits, and Prof.dr. A.E. Becker, Prof.dr. M. Borgers, Prof.dr. G. Gabbiani, and Prof.dr. H.J.J. Wellens for critically reviewing the manuscript.

Dr M.G Havenith initiated our interest in myofibroblasts in woundhealing, for which I would like to thank him.

I am very grateful to Mrs B. Kuypers and Ms M. Pijls who thaught me the intricacies of immunohistochemistry.

Dr.ir. J.P.M. Cleutjens, I thank for introducing me to the technique of in situ hibridization.

And last but not least the Cardio's (the cardiovascular research group of the dept. of Pathology): Thank you for all the support and encouragement I received during our colaboration. 


\section{CONTENTS}

1 Introduction 11

1.1 General 12

1.2 Causes of left ventricular hypertrophy (LVH) 13

1.2.1 LVH and volume overload 14

1.2.2 LVH and pressure overload 14

1.2.3 LVH and myocardial infaretion 17

1.3 Structural alterations in left ventricular hypertrophy 18

1.3.1 Structural alterations of the cardiomyocyte in LVH 18

1.3.2 Structural alterations of the interstitium in LVH 20

1.3.3 Structural alterations in heartvalves during LVH 26

1.3.4 Structurall alterations in the infarct 26

1.4 Regulation of structural allterations in LVH 27

$\begin{array}{lll}\text { 1.4.1 Sympathetic nervous system } & 28\end{array}$

1.4.2 Renin-angiotensin-aldosterone-system 28

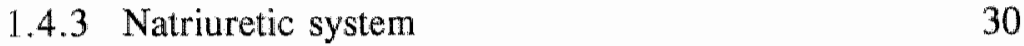

1.4.4 Cellular regulation 30

1.4.4.1 Basic fibroblast growth factor 31

1.4.4.2 Transforming growth factor- $\beta$ 31

1.5 Hypothesis 34

References $\quad 36$

2 Increased interstitial collagen in non-infarcted human 53 myocardium after myocardial infarction

3 Alpha smooth muscle actin positive cells in healing human 67 myocardial scars

4 Tenascin and fibronectin expression in healing human myocardial scars

5 Transforming Growth Factor B expression in healing human myocardial scars

6 Structural alterations in heart valves during left ventricular pressure overload in the rat

7 General discussion 
Summary

133

Samenvatting

Curriculum vitae 


\section{LIST OF ABBREVIATIONS}

Ang II

$\mathrm{ACE}$

$\mathrm{ACE} i$

AL

ANP

AS

ASMA

AT

$\mathrm{AT}_{1}$

$\mathrm{AT}_{2}$

AV

b-FGF

BNP

$\mathrm{B}_{2}$ receptor

CHF

DNA

ECM

FN

c-FN

$\mathrm{p}-\mathrm{FN}$

$\mathrm{HH}$

IHD

LF

LVH

MAP

MF

$\mathrm{MHC}$

$\alpha-\mathrm{MHC}$

B-MHC

MMP

mRNA

MV

NHH

PAS

RAAS

RT

PAI

SHR angiotensin $\mathrm{I}$.

angiotensin I converting enzyme.

angiotensin I converting enzyme inhibitor.

aorta ligation.

atrial natriuretic factor.

aortic stenosis.

$\alpha$-smooth muscle actin.

angiotensin III receptor.

angiotensin II receptor type 1 .

angiotensin II receptor type 2 .

aortic valve.

basic-fibroblast growth factor.

brain natriuretic factor.

bradykinin receptor type 2 . congestive heart failure.

deoxyribonucleic acid.

extracellular matrix.

fibronectin.

cellular fibronectin.

plasma fibronectin.

hypertensive hypertrophy.

ischemic heart disease.

labeling fraction.

left ventricular hypertrophy.

mean aterial pressure.

myofibroblast.

myosin heavy chain.

$\alpha$-myosin heavy chain.

B-myosin heavy chain.

matrix metalloprotease.

messenger ribonucleic acid.

mitral valve.

non-hypertensive hypertrophy.

periodic acid schiff.

renin angiotensin aldosteron system.

room temperature.

plasminogen activator inhibitor.

spontaneously hypertensive rat. 
SR

TGF- 8

TIMP

TV

WKY sarcoplasmic reticulum.

transforming growth factor $B$.

tissue inhibitor of metalloprotease.

tricuspid valve.

Wistar Kyoto rat. 
CHAPTER 1

INTRODUCTION 


\subsection{GENERAL INTRODUCTION}

Left ventricular hypertrophy (LVH) is both a clinical and a morphological condition of the heart, characterized by an increase in weight and size of the left ventricle in various pathophysiological settings (van-der-Laarse et al., 1989b).

In the Framingham Heart Study a large population has been studied and LVH has been defined as a cardiac mass of more than 100 and 131 grams per square meter body surface for women and men respectively (Hammond et al., 1986; Levy et al., 1987). In that study also the prevalence of LVH was observed to be $16 \%$ in the male population and $19 \%$ in the female population (Levy, 1988, 1991; Levy et al., 1990a). Age, arterial bloodpressure, obesity, valvular disease and myocardial infarction are all independent risk factors for LVH (Levy et al., 1988). Although the causes of LVH are heterogeneous, LVH itself is an independent risk factor for the occurrence of complex ventricular arrhythmias and sudden death (Cruickshank, 1992; Bikkina et al., 1993; Carre et al., 1993; Vaziri et al., 1994; Winterton et al., 1994).

The most important clinical manifestation following $\mathrm{LVH}$, however, is congestive heart failure (CHF; Braunwald \& Grossmann, 1992).

CHF is a relativelly common disorder; its frequency increases with age and doubles in each life decade. In the United States and Great Britain prevalences of 1 and 0.4 percent were calculated in the early nineties (Kannel \& Cupples, 1988). In the Netherlands a comparable percentage has been calculated for the prevalence of CHF. It is likely that the incidence of CHF will even increase in the next decades, since the mean age of the total population is still increasing (Reitsma, 1995), and the survival rate after acute myocardial infarction improves, due to more successful therapeutic interventions. Moreover the effect of treatment of CHF is poor. Advances in the treatment of hypertension, myocardial ischemia and valvular heart disease (all conditions leading to CHF), did not result in appreciable improvements in overall survival after the onset of congestive heart failure (Kannel \& Belanger, 1991; Ho et al., 1993). Similar data were obtained in Rochester Minnisota. Overall survival after the diagnosis of CHF was poor, with a $80 \%$ survival after 3 months and $66 \%$ at 1 year (Rodeheffer et al., 1993).

The therapeutic approaches in CHF can be divided in three main directions: reduction of the workload of the heart by arterial vasodilators, improvement of the pump function of the heart by positive inotropic agents such as digitalis glycosides and dopamine, and control 
of (excessive) salt and water retention by diuretics:

All groups of drugs mentioned lead to an improvement of the quality of life. However, Angiotensin I Converting Enzyme inhibitors (ACEi), initially thought to be solely strong vasodilators, may also have effects on the survival of CHF. In several trials an increase in the 6-month survival rate was observed in patient groups treated with a combination therapy including ACEi compared to therapy without ACEi (Cohn et al., 1986, 1991; Newman et al., 1988; Swedberg \& Kjekhus, 1990; The SOLVD investigators, 1991). The longterm effects on the survival rate of CHF remain to be determined.

Nevertheless, CHF remains lethal to a large extent. The disappointing results of therapeutical approaches so far may reflect the lack of our understanding of the pathophysiological mechanisms of LVH and CHF. The pathophysiological mechanisms not only include functional changes of the heart, but also changes of the structure of the heart (Weber, 1989; Chapman et al., 1990). These structural alterations are also called cardiac remodeling (Brilla et al., 1990). Understanding the structural alterations in left ventricular hypertrophy and its regulation, could be a key to the prevention of $\mathrm{CHF}$ as well as arrhythmias and sudden death.

Cardiac remodeling includes structural alterations of both the cardiomyocytes and the interstitium. Although several experimental studies have been performed describing interstitial remodeling in myocardial hypertrophy and during CHF (Chapnan et al., 1990b; Sun \& Weber, 1993; Teerlink et al., 1994), human data are limited. The studies described in this thesis will focus on the interstitial remodeling of human myocardium in left ventricular hypertrophy, following hypertension and myocardial infarction, and the possible role of mediators like $T G F-\beta$ in the regulation of the remodeling. The rat studies are restricted to the interstitial changes in heart valves during pressure overload.

\subsection{CAUSES OF LEFT VEN'TRICULAR HYPERTROPHY}

As already mentioned left ventricular hypertrophy is an increase in mass as well as in size of the heart. On a pathophysiological base LVH can be divided in three large groups: LVH due to volume overload, LVH due to pressure overload and LVH due to tissue loss (for instance myocardial infarction) (Katz, 1990b). The three types of LVH differ in clinical presentation and functional as well as structural characteristics. 
This will be discussed in the following paragraph. The structural alterations, due to the 3 types of $\mathbf{L V H}$, will be discussed in paragraph 1.3 .

\subsubsection{LVH AND VOLUME OVERLOAD}

Left ventricular hypertrophy induced by volume overload can be observed in patients with heart valve incompetence such as aortic and mitral valve incompetence. Due to the regurgitation of blood in aortic/mitral valve incompetence, a volume overload will occur, with dilatation and subsequent myocardial hypertrophy (Frohlich et al., 1992). The consequence of the eccentric hypertrophy is a normalized end-diastolic pressure, with normal oxygen consumption (Corrin et al., 1987; Nwasokwa et al., 1989).

The natural course of LVH due to both valvular incompetences is mild, compared to the other types of left ventricular hypertrophy (i.e. pressure overload and post myocardial infarction LVH). In the pre-surgical treatment era, the 5-years survival was $80 \%$ and the 10-years survival was $60 \%$, even in severe valvular regurgitation (Rapaport, 1975). Progression to CHF will occur, although in a much longer time span.

Another type of volume overload induced LVH is seen in longterm exercise. Under these conditions a similar hypertrophy of the left ventricle as seen in valvular regurgitation, with no progression to $\mathrm{CHF}$. In experimental studies thyroid hormone (thyroxine) is administered, leading to left ventricular hypertrophy, with similar functional (and structural) alterations comparable to seen in LVH induced by volume overload (Yao \& Eghbali, 1992; Polikar et al., 1993). Also here progression to CHF is seldomly seen.

\subsubsection{LVH AND PRESSURE OVERLOAD}

LVH as a result of pressure overload can be induced by a mechanical interference with the aortic outflow, but is mostly due to systemic hypertension (Braunwald \& Grossmann, 1992). The different clinical conditions will be discussed below.

\section{Obstruction of the aortic outflow tract}

The mechanical interference with the aortic outflow tract can be divided into subvalvular, valvular or postvalvular. In this context the valve mentioned is the aortic valve. The obstruction will in all cases lead to an 
increased demand on the contractile forces of the heart, which will result in hypertrophy of the left ventricle (Morrow \& Braunwald, 1959; Braunwald \& Grossmann, 1992).

There are at least two distinct forms of subvalvular aortic stenosis. One is called "discrete subaortic stenosis", which is a congenital malformation consisting of a membranous diaphragm encircling the left ventricular outflow tract.

A second form of subvalyular obstruction is hypertrophic cardiomyopathy. This entity was not systematically studied until the 1950's (Morrow \& Braunwald, 1959; Braunwald, 1989). Characteristic features of hypertrophic cardiomyopathy are myocardial hypertrophy, mostly of the interventricular septum of a non-dilated left ventricle, with a hyperdynamic ventricular function (Maron et al., 1987). A distinctive clinical feature in the minority of patients, is a dynamic pressure gradient in the left ventricle, with a high pressure apical part and a low pressure subvalvular part of the left ventricle (Fowler, 1991). Most patients do not have an outflow tract obstruction but merely a disproportioned hypertrophy with regard to the hemodynamic load. The overall prevalence of hypertrophic cardiomyopathy is low, and estimated to average between $0.02 \%$ and $0.2 \%$ of the population (Hada et al., 1987; Codd et al., 1989). The disease appears to bear a autosomal dominant trait with variable expression in $50 \%$ of all patients. A missense mutation of the $\beta$-cardiac myosin heavy chain (MHC) gene which is located on chromosome $14 \mathrm{q}$, is associated with hypertrophic cardiomyopathy (Jarcho et al., 1989; Geisterfer-Lowerance et al., 1990; Solomon et al., 1990a, b; Nishi et al., 1994; Vosberg, 1994). A hybrid gene of $\alpha$ - and $\beta$-cardiac MHC has also been proposed (Taningawa et al., 1990). In later studies gene mutations coding for other proteins than MHC, such as $\alpha$-tropomyosin gene and cardiac troponin $\mathrm{T}$, have been associated with hypertrophic cardiomyopathy (Dausse \& Schwartz, 1993; Anderson, 1994; Hengstenberg \& Schwartz, 1994; Hengstenberg et al., 1994; Thierfelder et al., 1994).

Mechanical obstruction of the left outflow tract is mostly localized at the aortic valve (Roberts, 1973). Acquired aortic stenosis (AS) occurs in different pathophysiological settings; four distinct types can be identified: rheumatic AS, degenerative AS, atherosclerotic AS and calcific AS (Panidis \& Segal, 1986). Rheumatic AS is the result of adhesion and fusion of the commissures and cusps of the aortic valve. 
This will lead to stiffening and retraction of the free borders of the cusps. Calcific nodules are present on both sides of the cusps. The orifice is reduced to a rigid small round to triangular opening (Wailler, 1986).

Degenerative or "senile" calcific AS is the most common form of AS in adults requiring an aortic valvular replacement (Passik et al., 1987). Morphological calcified nodules are present at the base and the flexion lines of the cusps. Commissural fusion is not present;

The remainder of acquired AS consists of atherosclerotic AS, most frequently present in patients with severe hypercholesterolemia (Deutscher et al., 1984). Calcific AS is observed in patient with Paget's disease of the bone as well as in end-stage kidney disease (Strickberger et al, 1987). Hemodynamically significant aortic stenosis leads to massive LVH (Kennedy et al., 1968), and left ventricular failure, with subsequent backward failure. Changes secondary to backward failure occur in the pulmonary vascular bed, the right side of the heart and the systemic venous bed.

Postvalvular aortic stenosis is most commonly due to a congenital coarctation. An acquired coarctation, although very rare, has to be considered also. Takayasu arteritis is an example of such a coarctation. It is a relatively rare disease in western Europe and USA (Kerr et al., 1994), in contrast to Asia. Takayasu arteritis is not only confined to the aortic arch; other arteries are diseased as well. Systemic hypertension is present in $74 \%$ of all patients (Hashimoto et al., 1993), mostly due to renal artery stenosis (Kerr et al., 1994). The stenosis occurs as a result of intima thickening, and fibrosis of the media. Heart failure occurs in $28 \%$ of all patients (Yajima et al., 1994). In addition ventricular arrhythmias have been described. Complex ventricular arrhythmias in patients with Takayasu arteritis were associated with the presence of LVH, aortic regurgitation and decreased coronary reserve (Siburian et al., 1993). Although aortic regurgitation is present in a significant part of the patients, the LVH is concentric, due to the systemic hypertension and/or the aortic coartaction (Hashimoto et al., 1993).

Although several reports show an association of HLA B52 or B5 gene and the incidence of Takayasu arteritis (Yoshida et al., 1993; Yajima et al., 1994), the etiology of this arteritis is still unclear.

\section{Systemic hypertension}

Hypertension has been defined by the World Health Organisation as 
systolic pressure $>160 \mathrm{mmHg}$, and diastolic pressure $>95 \mathrm{mmHg}$. Borderline hypertension is defined as a systolic pressure between 140 $\mathrm{mmHg}$ and $160 \mathrm{mmHg}$, and a diastolic pressure between $90 \mathrm{mmHg}$ and $95 \mathrm{mmHg}$.

Hypertensive heart disease is the response of the heart to the increased afterload imposed on the left ventricle by the progressively increasing arterial pressure (Frohlich et al., 1992). Hypertensive heart disease can have various cardiac manifestations such as LVH (Savage et al., 1990), coronary artery disease (Kannel et al., 1990; Levy et al., 1990b) and subsequent myocardial ischemia, cardiac dysrhythmias and congestive heart failure (Braunwald \& Grossmann, 1992). Longstanding hypertension is evaluated to triple the risk for CHF from $1 \%$ to 3\%(Kannel \& Cupples, 1988).

\subsubsection{LVH AND MYOCARDIAL INFARCTION}

Ischemic heart disease (IHD) is still the most common cause of death in western Europe and in the USA. In the Netherlands $30 \%$ of the deaths in 1992 was the result of IHD $(18,799$ females and 20,478 males; ref. Reitsma, 1995). IHD may present as anginal complaints, acute myocardial infarction, or sudden death. Acute myocardial infarction results in loss of myocardial tissue with subsequent diminution of left ventricular function. The reduced cardiac output will lead to activation of peripheral and cardiac compensatory mechanisms. Through an interplay of sino-aortic and cardiopulmonary baroreflexes (activated by cardiac output and cardiac filling pressure respectively) sympathetic nervous system activity will increase and arteriolar vasoconstriction will occur (Drexler et al., 1989). The Renin Angiotensin Aldosterone System (RAAS) will also be activated (Brilla et al., 1993; Sun \& Weber, 1993; Sun et al., 1994). Increased levels of angiotensin II will induce vasoconstriction. Aldosterone will promote salt and water retention in the kidney. Both activities will lead to restoration of the perfusion pressure of the tissue.

The left ventricle has to regain its integrity by forming scar tissue at the infarcted area. The cardiac compensatory mechanisms to restore the cardiac output have to be performed by the remaining viable myocardium, through remodeling of the left ventricle, resulting in dilatation and hypertrophy of the left ventricle. Initially the cardiac remodeling is beneficial to the function. The increased stiffness of the heart, however, will eventually reduce the cardiac compliance and 
attenuate the cardiac function with progression to CHF (Pfeffer \& Braunwald, 1990). Not only infarct-size but also localization of the infarct within the sferical anatomy of the heart are important in the progression to $\mathrm{CHF}$. Therefore not only symptomatic myocardial infarctions (surviving 1 year) but also silent myocardial infarctions are predisposing for $\mathrm{CHF}$. The prevalence of $\mathrm{CHF}$ post infarction doubles from $1 \%$ to $2 \%$ (Kannel \& Cupples, 1988). Once CHF is present, the prognosis is infaust, as already discussed.

\subsection{STRUCTURAL ALTERATIONS IN LVH}

As has emerged from the above, the different types of LVH have a different prognosis. LVH induced by volume overload seldomly progresses to CHF, in contrast to LVH both induced by pressure overload or myocardial infarction (Kennedy et al., 1968; Pfeffer \& Braunwald, 1990). A possible explanation for this difference in prognosis could be the differences in structural alterations of the myocardium in the different forms of LVH.

The myocardium consist of cardiomyocytes and the interstitium. The cardiomyocytes make up $70 \%$ of the volume of the heart, but only $30 \%$ of the amount of cells. The interstitium represents the largest fraction of myocardial cells, and includes endothelial cells, smooth muscle cells, nerves and fibroblasts. It does not only contain cells but also extracellular matrix. Changes in both the myocytes and the interstitium have been documented in cardiac remodeling during the development of LVH and will be discussed below.

\subsubsection{STRUCTURAL ALTERATIONS OF THE CARDIOMYO- CYTE IN LVH}

Cardiomyocytes are terminally differentiated cells and are believed to have lost the ability to divide. An increase in cell size of the cardiomyocytes therefore, seems to be the only way to gain mass. Indeed cardiomyocyte hypertrophy (increase of size) has been described in all types of cardiac hypertrophy (Loud et al., 1978; Anversa et al., 1986; Weber et al., 1992). Some authors, however demonstrated myocyte hyperplasia, that is an increase in cardiomyocyte number, in both humans and animals, during aging and hypertrophy (Olivetti et al., 1987; Grajek et al., 1993; Kajstura et al., 1994). 
The cardiomyocytes contain a contractile unit consisting of actin and myosin. Two major myosin heavy chain ( $\alpha$ and $B$ ) and four major myosin light chain isoforms have been demonstrated. In non hypertrophic hearts $\alpha$-Myosin Heavy Chain ( $\alpha-\mathrm{MHC}$ ) is the predominant contractile protein of the cardiomyocyte. In LVH as a result of both pressure overload and myocardial infarction the cardiomyocytes change the phenotype of contractile proteins. In several experimental studies the ratio of $B$-Myosin Heavy Chain (B-MHC) and $\alpha$-MHC changes in pressure overload, with a shift to the B-MHC isoform (Schwartz et al, 1992; Ojamaa et al., 1994). This shift of MHC type has not only been documented in experimental studies but also in humans (Bouvagnet et al., 1989).

Overall MHC synthesis is increased in pressure overload, but not in volume overload, where MHC synthesis is comparable to the synthesis rate in normal myocardium (Imamura et al., 1994). Also the presence of atrial light-chain-1 (ALC- 1 ) in both ventricles increases in the human hypertrophic heart secondary to mechanical stress (Hirzel et al., 1985). Next to these MHC changes, an increase in $\alpha$-skeletal actin is documented in pressure overload induced LVH (Schwartz et al., 1986, 1992; Schiaffino et al., 1989).

Contraction of cardiomyocytes is triggered by $\mathrm{Ca}^{2+}$ release from the sarcoplasmic reticulum (SR) through a $\mathrm{Ca}^{2+}$ channel (Endo, 1977; Wagenknecht et al., 1989). To investigate the underlying mechanism of the altered contractility several experimental studies have been performed (for review see Arai et al., 1994). Several changes in calcium metabolism have been found. For example in LVH post myocardial infarction, SR $\mathrm{Ca}^{2+}$ uptake was decreased in the viable left ventricular myocardium, and increased in the right ventricle (Afzal \& Dhalla, 1992). In LVH due to pressure overload or volume overload SR Ca ${ }^{2+}$ uptake was increased (Komuro et al., 1989; de la Bastie et al., 1990; Levitski et al., 1991). In congestive heart failure following the LVH of all types, SR Ca ${ }^{2+}$ uptake was decreased (Araj et al., 1994). The uptake of $\mathrm{Ca}^{2+}$ does not only occur across the SR membrane but, to a lesser extent also across the sarcolemma of the $\mathrm{Na}^{+}-\mathrm{Ca}^{2+}$ exchanger and the plasma $\mathrm{Ca}^{2+}$ pump. $\mathrm{Na}^{+}-\mathrm{Ca}^{2+}$ exchanger gene expression is enhanced in failing human hearts. This may, partially, compensate the depressed SRfunction in human failing myocardium (Studer et al., 1994). 


\subsubsection{STRUC TURAL ALTERATIONS OF THE INTERSTITUM IN LVH}

Although the mass of the heart predominantely consists of cardiomyocytes, the interstitium is the main cellular part of the myocardium. The cellular interaction and regulation of the remodeling of the myocardium is largely dependent on the interstitium. This may suggest that changes in the interstitium may have major influences on the function of the heart, as has already been suggested in experimental studies (Doering et al., 1988; Weber et al., 1989b).

\section{The extracellular matrix.}

The interstitium consists of extracellular matrix and connective tissue cells (Eghbali et al., 1989b; Bishop et al., 1990). The extracellular matrix is a complex of macromolecules, which can be divided in at least five major components: collagen, basement membrane, elastic fibers, proteoglycans and structural glycoproteins (Weber et al., 1994).

Collagen is the major component of the cardiac interstitium. Several studies have indicated that the amount, composition and distribution of interstitial collagen determines the stiffness of the heart, which is an important denominator of myocardial function (Doering et al., 1988; Weber el al., 1989b). For example in rat myocardium 4 weeks after aorta binding the diastolic stress-strain (passive stiffness) increases along with an accumulation of collagen in the interstitium (Doering et al., 1988; Weber et al., 1989a). The fibrillar collagen network in the myocardium is subdivided in three components the epimysium, perimysium and endomysium. These compartments are in continuity with valve leaflets and chordae tendinea (Robinson et al., 1988). The epimysium is located on the epi- and endocardium, where it gives rise to the perimysium. The perimysial fibers are located throughout the heart and in between cardiomyocytes (fig. 1). Their function is to connect groups of cardiomyocytes to form bundles. The endomysium arises from the perimysium and directly surrounds cardiomyocytes and capillaries to connect them through endomysial struts. In figure 1 the relation between these three components is schematically drawn. The collagens are a family of closely related proteins, with common properties. The most important collagens present in myocardium are collagen type I, III and IV (Villari et al., 1993). Collagen type $I$ is a heterotrimer consisting of two $\alpha I(I)$ chains and one $\alpha 2(I)$ chain. The protein is organized in thick bundles and has an extreme tensile force (Weber, 1989). Collagen type III functions as the centre to which collagen type I and other collagen 


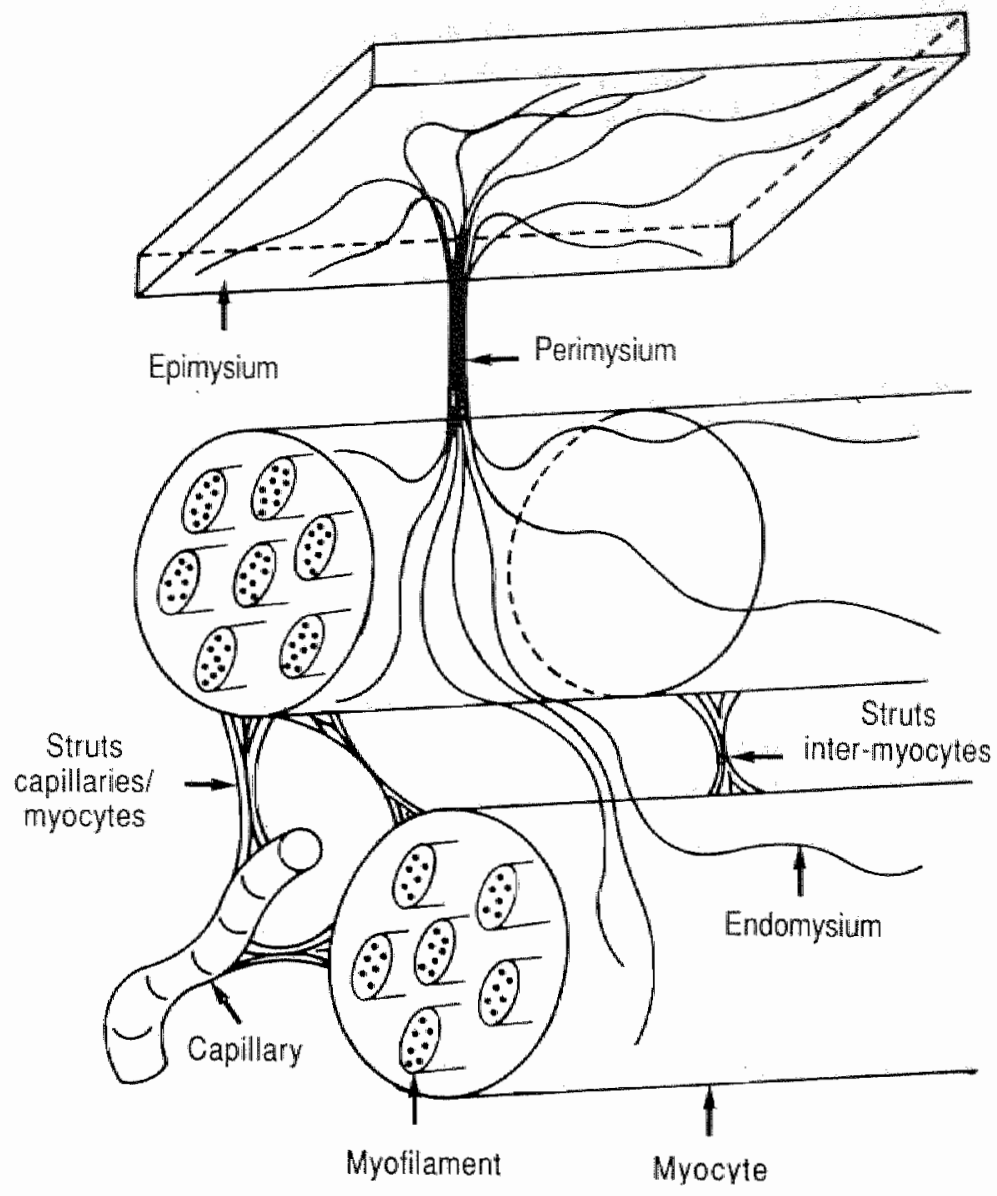

Figure 1. Diagram of three dimensional arrangement of collagen fibers in the myocardium. (redrawn from Borg et al, 1981)

types can attach, thus forming collagen fibers. Due to crosslinking of these collagen fibers the network gains strength. Collagen type III is, in contrast to type I, a homotrimer consisting of $\alpha 1$ (III) chains. It forms thin fibers, predominates in embryonic tissue, but is also present in adult myocardium and is the first collagen deposited during both dermal and myocardial woundhealing (Chapman et al., 1990).

The amount of both proteins is increased in $\mathrm{LVH}$ induced by pressure overload and myocardial infarction. The increase in collagen content has 
been documented in experimental studies (Doering et al., 1988; Carroll et al., 1989; Pick et al., 1989a; Contard et al., 1991; Smits et al., 1991) and human studies (Caspari et al., 1977; Schwarz et al., 1978; Pearlman et al., 1982; Schaper \& Schaper, 1983; Huysman et al., 1989; van-derLaarse et al., 1989a; Volders et al., 1993; this thesis) and has been defined as a disproportionate accumulation of collagen, called fibrosis (Weber et al., 1994). In contrast to LVH induced by pressure overload or myocardial infarction, fibrosis is not present in LVH induced by volume overload (Michel et al., 1986; Yao \& Eghbali, 1992; Weber et al., 1994). The fibrosis itself is associated with negative effects on heart function (Schoemaker et al., 1991; van Krimpen et al., 1991.b).

The collagen content is the result of collagen production as well as degradation of collagen (Guarda et al., 1993a; Cleutjens et al., 1995a; Weber et al., 1995). The increased collagen content in LVH is a result of an increase in local collagen production (mRNA increase). The mRNA"s of collagen I and III are increased in experimental LVH induced by aortic binding (=pressure overload). Similar findings are described in LVH post myocardial infarction (Cleutjens et al., 1995b). The mRNA increase is located in cardiac fibroblasts, as visualized by in situ hybridization (Eghbali et al., 1989a, b; Cleutjens et al., 1995b). In normal myocardium collagen has an estimated half-life time between 80 to 120 days (Weber, 1989). Collagen is degraded by local proteolysis (Chakraborty \& Eghbali, 1989). This degradation of collagen, necessary in woundhealing and tissue remodeling, is the result of activation of matrix metalloproteinases (MMP's) and neutrophil elastase (NE). MMP's are localized in the heart in a latent form throughout the interstitium and in the vicinity of endothelial cells (Weber et al., 1994). The activation of MMP's can occur through extracellular activation by serine proteases, such as trypsin or kallikrein. Activated MMP's can be blocked by Tissue Inhibitors of metalloproteinases (TIMP). Purified TIMP"s however can be inactivated, at least in vitro, by serine proteases indicating an effect of serine proteases by activation of MMP's and by inhibiting the blockade of MMP's (Okada et al., 1988). In myocardial infarction the infarcted and to a lesser extent also the non-infarcted area both demonstrate an enhanced collagenolytic activity (Tyagi et al., 1993; Cleutjens et al., 1995a).

The last protein of the collagen family, present in the heart and discussed here is collagen type IV, a homotrimer of $\alpha \mathrm{I}$ (IV) chains, which is found exclusively in basement membranes of both cardiomyocytes and cells of the interstitium (Havenith et al., 1987). 
Although it does not form individual fibers but associates with other basement membrane components, collagen type IV mRNA is also increased in pressure overload LVH (Chapman et al., 1990b). The protein content, however, does not change. This is most likely the result of increased turnover of the protein, due to degradation.

Collagen IV attaches to proteins such as laminin. Laminin is a glycoprotein, susceptible to several proteases and its function is cell adhesion and attachment. During LVH induced by pressure overload an increase in laminin has been observed in the basement membranes of the left ventricle of the heart (Lipke et al., 1993). Entactin is also a constituent of the basement membrane. It interacts with laminin but its precise function still remains unclear. The entactin content in LVH is unknown. Heparan sulfate proteoglycans contain a central protein core with several polysaccharides covalently bound. Their major function is maintaining electrostatic charge and fluid balance. The basement membrane proteins are in close relation with the cardiomyocytes as well as the vasculature. The proteins are therefore connected to the endomysium (figure 1).

Structural glycoproteins are fibronectin and tenascin. Fibronectin is a dimeric glycoprotein located in the extracellular matrix of most tissues that influences cellular properties including adhesion, growth and woundrepair, through an interaction with cell surface receptors (fibronectin receptors) (Matsumoto et al., 1994). In normal myocardium fibronectin is present in the atria and to a lesser extent in the ventricles (Mamuya \& Brecher, 1992). Multiple isoforms of fibronectin can be present, arising by alternative splicing. The protein is present in a cellular form (c-FN) synthesized and secreted locally by interstitial cells (Vartio et al., 1987) and a plasma form (p-FN), synthesized and secreted by hepatocytes (Oh et al., 1981; Tamkun \& Hynes, 1983). Fibronectin is composed of three repeats. The type I and II repeats are homologous in both $\mathrm{c}-\mathrm{FN}$ and $\mathrm{p}-\mathrm{FN}$. The sequence variations occur in the third repeat (type III) at three points: extra domain (ED) A, B or IIICS in human and EIIIA, EIIIB and V in rat (Gutman \& Kornblitt, 1987; Schwartzbauer et al., 1987). The cellular form may include ED A or B, the plasma form does not. The ED A, and B variant are present during embryogenesis, and during tissue repair (Samuel et al., 1991).

$\mathrm{C}-\mathrm{FN}$ and $\mathrm{p}-\mathrm{FN}$ are present in woundhealing preceding other extracellular matrix proteins (ffrench-Constant et al,, 1989). In myocardial infarction in the rat plasma fibronectin is internalized in the cytoplasm of viable cardiomyocytes, surrounding the infarction and 
ischemic cardiomyocytes (Shekhonin et al., 1990). Immunohistochemically p-FN can be identified 24 hours after experimental myocardial infarction. Three days after myocardial infarction an increase in the mRNA levels of c-FN is present and c-FN protein can be seen (Knowlton et al., 1992). In human as well as in rat myocardial woundhealing fibronectin disappears after collagen deposition (Shekhonin et al., 1988; Casscells et al., 1990).

C-FN is not only present in infarct healing but also in LVH induced by pressure overload. Both mRNA and protein are increased (Samuel et al., 1991; Mamuya \& Brecher, 1992). The cell-type responsible for the production of c-FN still has to be elucidated. Endothelial cells as well as fibroblasts seem to be potential candidates. In cultured myocardial fibroblasts, fibronectin production was present (Crawford et al., 1994). One of the regulators of fibronectin production both in vivo and in vitro is angiotensin II (Villarreal et al., 1993).

Tenascin is a large hexameric protein, with fibronectin type III domain repeats preceding the c-terminal (Vrucinic-Filipi \& Chiquet-Ehrismann, 1993). The protein is present in embryonic tissues, especially in embryonic kidney (Truong et al., 1994), but also in normal adult human tissues, such as skin (Shikata et al., 1994). This macromolecule appears to be involved in cellular interactions in embryogenesis and pathological conditions such as chronic liver disease, prostatic hyperplasia and several carcinomas (Ibrahim et al., 1993; Jaskiewicz et al., 1993; Meiners et al., 1993). In human dermal wound healing tenascin expression increases in combination with (tissue) fibronectin (Juhasz et al., 1993). In both experimental and human dermal woundhealing tenascin is observed after 1-2 days and remains present for 1 month (Betz et al., 1993; Luomanen \& Virtanen, 1993; Kanno \& Fukuda, 1994). So far there are no data on the localization of tenascin in rodent or human myocardium.

The cardiac interstitial cells

Next to the extracellular matrix (ECM; described above), the interstitium contains a cellular part, consisting of fibroblasts, and capillaries (i.e. endothelium and pericytes) (Doering et al., 1988; Weber et al., 1989b). Capillaries surround cardiomyocytes, and are potent producers of cytokines such as endothelin and b-FGF (Katwa et al., 1993; Lindner \& Reidy, 1993). Angiogenesis is essential for cardiac growth and also plays a role in LVH. In all types of LVH an increase in 
capillaries is present. Although literature is ambiguous about the absolute or relative increase in capillaries, surrounding the hypertrophic cardiomyocytes (Izumi et al., 1984; Rakusan et al., 1992; Yarom et al., 1992), the general opinion is that a decrease in capillary/fiber ratio is present during LVH induced by pressure overload in contrast to a constant capillary/fiber ratio during volume overload. The decrease, however, depends on the pressure overload model used, as well as the species and their age (Tomanek et al., 1991).

Cardiac fibroblasts, unlike cardiomyocytes, retain their mitotic capacity, and multiply actively in pathophysiological conditions such as aging and pressure overload (Lenkiewicz et al., 1972; Pick et al., 1989b). Fibroblasts are mesenchymal cells with the potential of producing components of the extracellular matrix (Weber et al., 1988). This production can be modulated both by circulating and local stimuli. As described before, mRNA collagen I and III are increased in LVH. With in situ hybridization, the presence of these mRNA's was localized in the interstitial cells, most likely fibroblasts (Eghbali et al., 1989a; Cleutjens et al., 1995a). Interestingly in a co-culture of fibroblasts and endothelial cells, the endothelial cells increase collagen production and degradation by fibroblasts. This modulation could not be influenced by either aldosterone nor angiotensin II (Guarda et al., 1993b). Under certain conditions, fibroblasts are susceptible to phenotypic modulation. In several tissues, but mostly shown in dermal woundhealing (Sottiurai \& Batson, 1983; Vande-Berg et al., 1984; Battersby \& Anderson, 1985; Tomasek et al., 1986; Matsuoka et al., 1988; Stout et al., 1988; Adler et al., 1989; Pourreau-Schneider et al., 1990) fibroblasts are capable of expressing $\alpha$ smooth muscle actin (ASMA) in cytoplasmic filaments (Skalli et al., 1986; Darby et al., 1990). Ultrastructurally these filaments have sublemmal attachments plaques and dense bodies, characteristics of smooth muscle cells. This fibroblast phenotype therefore has been called myofibroblast (Gabbiani et al., 1971, 1984; Skalli et al., 1986, 1989). Myofibroblasts are also present in the heart. Especially after myocardial infarction myofibroblasts could be identified in the infarcted area (table 1 of chapter 3), not only in rodent hearts, but also in human infarcted myocardium (Vracko et al., 1989, 1991; Leslie et al., 1991; Vracko \& Thorning, 1991; Willems et al., 1994, and chapter 3 of this thesis). Scar contraction during woundhealing is a result of the activity of these myofibroblasts (Baur et a1., 1984). Myofibroblasts are not only present in the interstitium of the heart but also in (chordae tendinea of) the mitral valve (Filip et al., 1986). 


\subsubsection{STRUCTURAL ALTERATIONS IN HEARTVALVES DURING LVH}

Heart valves consist solely of interstitium, and are devoid of cardiomyocytes. The fibrillar network of collagen surrounding the cardiomyocytes throughout the heart, is continuous with the chordae tendineae and valve leaflets (Robinson et al., 1988).

Ventricular as well as atrioventricular valves consist of a lamina fibrosa, which is very compact, with relatively few fibroblasts, and a lamina spongiosa, which has a rather loose structure and more cells. Heartvalves are lined by the endocardium.

In vitro studies of mitral valvular interstitial cells demonstrated the existence of two phenotypes, a spindle shaped or elongated phenotype and a cuboidal or cobble stone phenotype (Johnson et all., 1987; Lester et al., 1988; Zacks et al., 1991). These two phenotypes could be modulated in culture: high serum concentrations caused a shift to the cobble stone phenotype, while the elongated cells dominated in low serum concentration. Other, in vivo, studies showed that at least a fraction of the valvular fibroblasts contained $\alpha$-smooth muscle actin filaments, thereby being myofibroblasts (Fillip et al., 1986).

Although clinical evidence is present for the effect of valvular disease on the myocardium (paragraph 1.2.2; LVH), no studies have been performed demonstrating the effect of pressure overload on heartvalves.

\subsubsection{STRUCTURAL ALTERATIONS IN THE INFARCT}

The structural alterations in the non-infarcted hypertrophied myocardium have been described in earlier paragraphs. It may have become clear that left ventricular hypertrophy due to pressure overload and myocardial infarction share many characteristics. A unique feature of the myocardial infarction, however, is the formation of scar tissue. In early histological studies several hallmarks of human myocardial woundhealing have been described (Bouchardy \& Majno, 1974). During the first day the cardiomyocytes in the centre of the infarction become necrotic and show a loss of cross-striation. A granular debris within the sarcolemma will be present. Also within the first day an influx of leucocytes will occur, probably due to stimulation of lysosomal proteases and cleavage of complement chemotactic factors. On day 3 leucocytes are most prominently present in the border of the necrosis. At day four macrophages, as well as (myo)fibroblasts are present in the 
infarct area. New vessels are formed, and extracellular matrix proteins are deposited. Collagen fibers are morphologically evident by day 7 postinfarction, while organized assembly of these fibers will become evident at day 14. Scar tissue, with mature crosslinked collagen will be present after 6-8 weeks (McGormick et al., 1994).

A fresh myocardial wound is a very fragile part in the ventricle, on which large tensile forces are acting throughout the heartcycle. Infarct remodeling, therefore, is essential in maintaining the function of the heart.

In experimental studies of myocardial infarctions production of extracellular matrix components is described. The model most often used is the rat infarct model in which the left anterior descending coronary artery is ligated (Schoemaker \& Smits, 1990). Fibronectin, both plasma and cellular, is present in recent myocardial infarction in the rat, preceding other ECM components such as collagen (ffrenchConstant et al., 1989; Casscells et al., 1990; Shekhonin et al., 1990; Knowlton et al., 1992). Other early matrix proteins, such as tenascin, are not studied in the myocardium. The interstitial cells in the infarcted area, are studied, again, mostly in non-human species. Phenotypic modulation of (myo)fibroblasts was discussed above. Myofibroblasts appear 3 days after myocardial infarction in the rat, and are still present after 21 days, which is the longest time period studied (Faber et al., 1986; Leslie et al., 1991; Vracko \& Thorning, 1991). These myofibrobllasts have the ability to contract, and could be responsible for contraction of the scar (Baur et al., 1984). Although in vitro and in vivo studies document the regulation of myofibroblast-modulation, especially in dermal wounds (Thiemermann \& Corder, 1992; MacLellan et al, 1993), comparable studies in the myocardium are lacking.

Summarizing the histological phenomena of the infarct healing, however may not lead to more understanding of post myocardial infarction complications. A more detailed knowledge of the actual remodeling of the infarct and its regulation is necessary. This knowledge could possibly open new therapeutic interventions with regard to infarctrupture, aneurysm-formation, and even development of CHF.

\subsection{REGULATION OF STRUCTURAL ALTERATIONS IN LVH}

Regulators of the structural alterations in LVH can be divided in mechanical (i.e. stretch), local (RAAS, atrial natriuretic peptide, 
cytokines), and systemic factors (RAAS and sympathetic nervous system).

\subsubsection{SYMPATHETIC NERVOUS SYSTEM}

A reduction in cardiac output activates the sino-aortic baroreflex and an increase in cardiac filling pressure can result in an activation of cardiopulmonary baroreceptors. Sympathetic activation will be the result. In the myocardium both $\alpha$-and $B$-adrenoreceptors are present on cardiomyocytes and interstitial cells. In vitro studies have demonstrated that stimulation of only $\alpha_{1}$-adrenoreceptors induces hypertrophy in neonatal cardiomyocytes (Long et al., 1993). B-Adrenoreceptor stimulation did not lead to cardiomyocyte hypertrophy. Activation of the sympathetic nervous system also results in the synthesis of collagen in the myocardial interstitium (Feldman et al., 1991).

\subsubsection{RENIN-ANGIOTENSIN-ALDOSTERONE-SYSTEM}

The Renin-Angiotensin-Aldosterone-system is a neurohumoral system of which angiotensin II is the active protein. Angiotensinogen is the "primer" protein of this system and is produced in the liver and cleaved by Renin in the decapeptide angiotensin I. Angiotensin I is converted by Angiotensin I Converting Enzyme (ACE) in the active octapeptide angiotensin II (AngI). Degradation of AngII results in two amino-acid peptides, angiotensin III and angiotensin(1-7). Both peptides stimulate prostaglandin formation. In addition angiotensin III stimulates aldosterone secretion. Angiotensin(1-7) increases vasopressin release.

Next to the classical circulating RAAS, the presence of a local cardiac RAAS has been suggested. Components of the RAAS have been demonstrated in several organs and tissues, including the heart, vascular wall, adrenal gland, brain and kidney. In the hypertrophied rat heart after aorta ligation increased levels of angiotensinogen and ACE mRNA have been described (Schunkert et al., 1990). Renin mRNA has also been reported in the normal human myocardium, although its regulation has to be elucidated (Paul et al., 1993). ACE binding has been demonstrated within the intramural coronary arteries, and the matrix of heart valves. High density ACE-binding is present in myocardial infarction of 4 weeks postinfarction time (Sun et al., 1994). Both mRNA as well as the protein ACE appears to be localized at the border of the infarction at endothelial cells (Passier et al., 1995), suggesting a 
regulatory role $\mathrm{ACE}$ in angiogenesis. Although angiogenesis is also essential to woundhealing, we will focus on the effects of the RAAS on extracellular matrix production. The presence of local ACE formation may result in enhanced collagen production, and a decrease of collagen degradation. ACE however, is allso active as kinase II which degrades bradykinin into inactive metabolites. Bradykinin is an inhibitor of fibrous tissue formation, by decreasing collagen production and increasing the collagenolytic activity (Sun \& Weber, 1993; Sun et al., 1994). Both effects are mediated by the Bradykinin $B_{2}$ receptor, which is present in fibrous tissue of the heart (Sun et al., 1993). Not only collagen production is increased by AngII. Recent in vitro as well as in vivo studies demonstrated an increased fibronectin production of fibroblasts (Villarreal et al., 1993; Crawford et al., 1994).

Stretch of cardiomyocytes, as in hypertrophy of all types, has been documented to induce autocrine release of angiotensin II (Sadoshima et al., 1993). It is suggested that angiotensin $\mathbb{I I}$ is an initial mediator of hypertrophy of cardiomyocytes. It also presents a pathophysiological role for a local RAAS. Several authors (Katz, 1990a) suggested that AngII is directly involved in cardiomyocyte DNA synthesis. Increased DNA synthesis and differentiation of both cardiomyocytes and vascular smooth muscle cells as a result of AngII administration have been demonstrated (Daemen et al., 1991; Paul et al., 1993).

Similar findings are demonstrated for interstitial cells. AngII has been shown to induce DNA synthesis in cardiac fibroblasts (Aceto \& Baker, 1990; Baker et al., 1990; Brilla et al., 1994). In vivo DNA synthesis and fibroblast proliferation occur after myocardial infarction as a response to AngII. The proliferation is blocked by early administration of the ACE inhibitor Captopril treatment (van-Krimpen et al., 1991a). In vitro collagen synthesis by cardiac fibroblasts has been demonstrated and is increased by AngII administration (Brilla et al., 1994). In addition collagenase activity in these fibroblasts was reduced. Both responses would favour collagen deposition. In vivo, in the rat, collagen protein and mRNA contents both are augmented by AngII and protein production is blocked by early administration of ACEi. Administration of a non-hypertensive dose of angiotensin II in rats without myocardial infarction results in myocyte necrosis and subsequent fibrosis (Ratajska et al., 1994). After adrenalectomy the fibrosis is less pronounced. As these rats have low circulating catecholamines, it is suggested that angiotensin II has an indirect action on cardiomyocyte necrosis, via circulating catecholamines (Ratajska et al., 1994). AngII is active 
through an angiotensin receptor (AT). At least two types of the angiotensin receptor have been described with several subtypes (Iwai et al., 1991; Murphy et al., 1991). $\mathrm{AT}_{1}$ and $\mathrm{AT}_{2}$ have been identified in rabbit cardiac membrane preparations. Next to membrane receptors, receptors located in the cardionyocyte nucleus have been identified (Re, 1987). Recent studies suggest that cardiomyocyte hypertrophy and fibroblast hyperplasia in $\mathrm{LVH}$ are induced by $\mathrm{AT}_{1}$ mediated angiotensin II activity (Sadoshima \& Izumo, 1994). During long-term Ang II treatment in rats $\mathrm{AT}_{1}$ receptors are down regulated, while during aldosterone treatment an upregulation is present (Weber et al., 1994). In these reports fibrous tissue did not colocalise with the $\mathrm{AT}_{1}$ receptor. Other studies documented an upregulation of $\mathrm{AT}_{2}$ receptors in $\mathrm{LVH}$ in the rat (Suzuki et al., 1993; Lopez et al., 1994).

\subsubsection{NATRIURETIC SYSTEM}

The natriuretic system is a regulatory loop of which atrial natriuretic peptide (ANP) is the active component. ANP has been described in several tissues and organs such as heart, liver, kidney, lungs, intestine and testicles. The ANP mRNA is translated into a pre-prohormone of 151 amino acids long. The propeptide has a length of 126 amino acids, and is stored in this form in the atrial granules. The active peptide, $\alpha$ ANP, is 28 amino acids long, and has diuretic, natriuretic and vasorelaxant activities (Mercadier et al., 1989). The interaction with the RAAS is present through inhibition of aldosterone secretion by the adrenal gland and renin release by cells of the juxtaglomerular apparatus (Yasue et al., 1994). ANP protein as well as gene expression is also increased in left ventricular hypertrophy induced by pressure overload (Mercadier et al., 1989). This increase can be mediated by AngII administration, as rapid as 6 hours post administration (Sadoshima \& Izumo, 1994). A novel cardiac natriuretic peptide, the B-type natriuretic peptide (BNP), has been identified in pig brain (Sudoh et al., 1988). In normal human hearts BNP is mainly secreted by the ventricles, and the secretion increases in proportion to the severity of left ventricular dysfunction (Yasue et al., 1994).

\subsubsection{CELLULAR REGULATION}

Circulating or local neurohormonal factors will bind to receptors and induce changes in a network (signal transduction). This activation can 
stimulate effects on the cell itself but also on neighbouring cells (autocrine vs paracrine). The substances generating these autocrine or paracrine effects, are cytokines. These small proteins reside within a variety of cells, and in the extracellular matrix. Through receptor binding and subsequent signal transduction a diversity of actions can occur (Roberts \& Sporn, 1993). Some authors described cytokines as "switches", their function depending on the localization and amount of the cytokine (Long et al., 1993; Nishida et al., 1993). Several cytokines have been described to be active in myocardial hypertrophy. In this paragraph b-FGF and TGF- $B$ will be highlighted, because of their role in both LVH and scartissue formation.

\subsubsection{BASIC FIBROBLAST GROWTH FACTOR}

Basic fibroblast growth factor (b-FGF) is a cytokine with proliferative activity on different celltypes, such as fibroblasts and vascular smooth muscle cells. It is suggested that b-FGF has a role in angiogenesis associated with coronary collateral formation and wound healing (Padua \& Kardami, 1993). In the dog both systemic and local administration of b-FGF enhances collateral blood flow after experimental myocardial ischemia secondary to single-vessel coronary occlusion (Unger et al, 1994; Lazarous et al., 1995). This finding suggests an angiogenic effect of $b-F G F$, although other studies demonstrated an increase of endogenous a-FGF without an increase in b-FGF following myocardial infarction (Bernotat-Danielowski et al., 1993). This indicates that although exogenous b-FGF induces angiogenesis, the possible direct effects of b-FGF in angiogenesis have to be studied in antagonist experiments. As already stated, much of the action of cytokines depends on the amount and localization of that specific protein (Long et al, 1993). In an in vitro study using cultured human fibroblasts derived from keloid it is documented that $b$-FGF has a positive effect on mRNA collagen I production (Tan et al., 1993). Although b-FGF induces proliferation of fibroblasts in scar tissue formation, this cytokine is not able to induce phenotypic modulation of these fibroblasts into myofibroblasts, in contrast to TGF-13 (Desmouliere et al., 1993).

\subsubsection{TRANSFORMING GROWTH FACTOR-B}

TGF- $B$ is a 25-kilodalton homodimer, belonging to the Epidermal Growth Factor family (De Larco \& Todaro, 1978; Anzano et al., 1982). 
The protein was first identified in 1981 as a cytokine able to induce "anchorage-independent" growth of fibroblasts in vitro (Roberts et al., 1981). TGF-B was purified from human blood platelets (Assoian et al., 1983), human placenta (Frolik et al., 1983) and bovine kidney (Roberts at al., 1983). Five types of this cytokine, of which 3 are identified in humans, are known (Seyedin et al., 1985). TGF-B is present, in a latent form, in nearly all cells and can be activated for example by activated macrophages (Pilatte et al., 1987) or an acid environment (Silver et al., 1988). After activation, all isoforms of TGF- $B$ are capable of binding to at least 3 receptors, which are present on virtually all cells, although specific knowledge concerning the myocardium to this effect is lacking. Type I and II receptors, which are serine-threonine kinases, are capable of signal transduction (Ross et al., 1993a, b). The type III receptor, a betaglycan, presents TGF-B to other receptors, and has no signal pathway of its own (Lopez-Casillas et al,, 1994). The type I receptor mediates the effects of TGF- $\beta$ on extracellular matrix production. Cell proliferation and growth is mediated by the type II receptor (Sporn \& Roberts, 1992; Ebner et al., 1993).

The effects of transforming growth factor $\beta$ (TGF- $\beta$ ) are diverse and seem to depend on the local tissue context (Roberts et al., 1992a). In the adult heart TGF- $\beta_{1,2}$ and 3 has been demonstrated in cardiac myocytes, endothelium, smooth muscle cells, fibroblasts and conducting tissue (Ross et al., 1993a). Recent studies suggest that TGF- $\beta$ has cardioprotective effects. Administration of exogenous TGF-B after myocardial infarction diminishes myocyte necrosis, and decreases the presence of polymorphonuclear granulocytes (Lefer et al., 1992; Lefer \& Lefer, 1993). These results are probably due to the direct effects of TGF- $\beta$ on preservation of coronary vascular endothelial release of nitric oxide (NO) and curtailment of the formation of superoxide radicals which are known to inactivate NO (Roberts et al., 1992b).

The effect of TGF- $\beta$ on the interstitium is not completely elucidated. TGF $-\beta$ induces an increase in collagen production by fibroblasts (fig.2; Eghbali, 1992; Roberts et al., 1992a; Roberts \& Sporn, 1993). This nett increase in collagen content is the result of stimulation of matrix synthesis and inhibition of matrix degradation. As is represented schematically in figure 2, TGF-B activates gene transcription and increases synthesis and secretion of matrix proteins (Ignotz \& Massague, 1986; Pearson et al., 1988; Rossi et al., 1988). TGF-B also decreases secretion of proteases and increases the secretion of protease inhibitors (Overall et al., 1989). All actions result in an enhancement of 
extracellular matrix content. The "transforming effect of TGF-B on fibroblasts was demonstrated by Gabbiani and co-workers. They showed that the phenotype of cultured fibroblasts present in (dermal) woundhealing can be modulated by TGF-1. An increase in myofibroblast number occurs when TGF-13 is applied subcutaneously (Desmouliere et al., 1993). None of the other tested cytokines, including b-FGF, was able to induce this ASMA expression (Desmouliere et al., 1992; Vyalov et al., 1993).

From the discussion above it can be concluded that TGF-B is a omnipotent cytokine present in the heart. It has a role in ECM modulation, both in LVH and in woundhealing. No data however, are present on the possible role of TGF- $\beta 3$ in the heart in the modulation of the myofibroblast phenotype neither in experimental studies nor in humans.

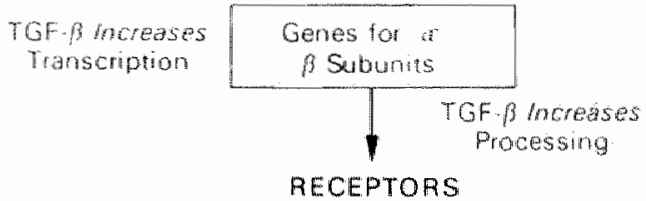

TGF- $\beta$ Stimulates

Matrix Synthesis

1

MATRIX PROTEINS

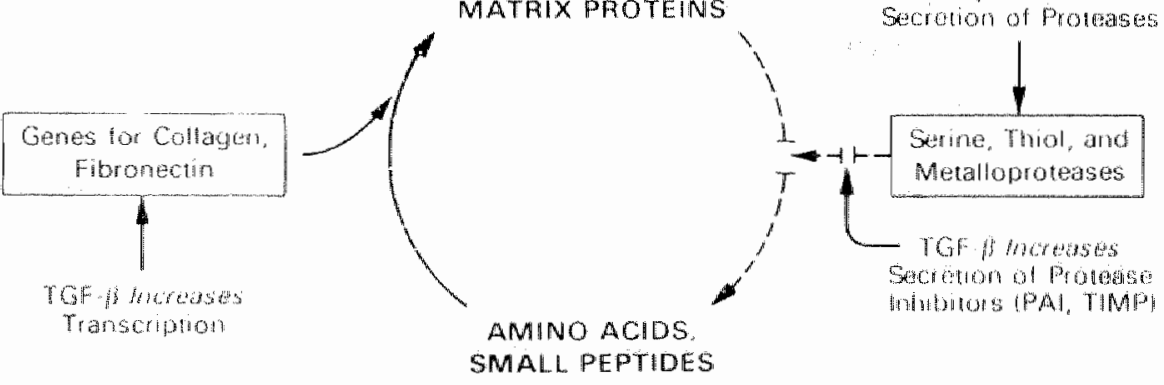

Figure 2. Mechanisms of TGF- $\beta$ enhancement of both production and degradation of extracellular matrix. PAI: plasminogen activator inhibitor; TIMP: tissue inhibitor of metalloproteases. (redrawn from Roberts \& Sporn, 1993).
COLLAGEN.

FIBRONECTIN

OTHER

TGF- $\beta$ Inhibits

Matrix Degradation

TGF $\beta$ Ducreases

Secrution of Proteases

sactation of Pritomes

AMINO ACIDS

SMALL PEPTIDES 


\subsection{HYPOTHESIS}

From the above it may be clear that LVH is not only associated with changes in the cardiomyocytes, but also with alterations in the cardiac interstitium. These interstitial changes may relate to the type of LVH (table 1). Left ventricular hypertrophy due to pressure overload and myocardial infarction, but not due to volume overload, show an increase in myocardial stiffness, which is associated with a disproportioned increase in extracellular matrix.

Table 1 Left ventricular hypertrophy, structural alterations and prognosis cap $/$ fib = capillary-fiber ratio; $\uparrow=$ increase; $==$ constant.

\begin{tabular}{|c|c|c|c|}
\hline & \multicolumn{2}{|c|}{ left ventricular hypertrophy } & \multirow[b]{2}{*}{ volume overload } \\
\hline & pressure overload & $\begin{array}{l}\text { post myocardial } \\
\text { infarction }\end{array}$ & \\
\hline cardiomyocyte & volume $\uparrow$ & volume $\uparrow$ & volume $\uparrow$ \\
\hline interstitium & collagen $\uparrow$ & collagen $\hat{\imath}$ & collagen $=$ \\
\hline & $\begin{array}{l}\text { fibroblasts DNA } \\
\text { synthesis } \uparrow\end{array}$ & $\begin{array}{l}\text { fibroblasts DNA } \\
\text { synthesis } \uparrow\end{array}$ & $\begin{array}{l}\text { fibroblasts DNA } \\
\text { synthesis = }\end{array}$ \\
\hline & $\mathrm{cap} / \mathrm{ib} \downarrow$ & cap/fib $\downarrow$ & $\mathrm{cap} / \mathrm{fib}=$ \\
\hline prognosis & $\begin{array}{l}\text { progression to } \\
\text { CHF }\end{array}$ & progression to $\mathrm{CHF}$ & $\begin{array}{l}\text { less progression to } \\
\text { CHF }\end{array}$ \\
\hline
\end{tabular}

Moreover the prognosis of patients with LVH due to both pressure overload and myocardial infarction is worse than that of patients with LVH due to volume overload. It is, therefore tempting to hypothesize that aberrant changes in the interstitium are responsible for the worse prognosis in LVH due to pressure overload and myocardial infarction. The literature however is almost devoid of studies presenting data of the regulation of changes in the interstitium in hypertrophied myocardium in humans. These data, however, could affirm experimental data, and may yield possible regulators of interstitial remodeling in the human myocardium.

This thesis will focus on left ventricular hypertrophy due to pressure 
overload and myocardial infarction. Discussed will be the interstitia remodeling in human myocardium in pressure overload and in the non infarcted myocardium post myocardial infarction, as well as th remodeling in the infarcted area, of human myocardium. Expression o TGF- $\beta$ protein in human infarct remodeling will also be described. Th interstitial remodeling of heart valve during pressure overload in rat will also be discussed. 


\section{REFERENCES}

Aceto IF, Baker KM. [Sarl]angiotensin II receptor-mediated stimulation of protein synthesis in chick heart cells. Am J Physiol (1990) 258:H806-H813.

Adler KB, Low RB, Leslie KO, Mitchell $J$, Evans JN. Contractile cells in normal and fibrotic lung. Lab Invest (1989) 60:473-485.

Afzal $N$, Dhalla NS. Differential changes in left and right ventricular SR calcium transport in congestive heart failure. Am J Physiol (1992) 262:H868-H874.

Anderson PA. Cardiovascular molecular genetics. Curr Opin Cardiol (1994) 9:7890 .

Anversa $P$, Beghi $C$, Kikkawa $Y$, Olivetti $G$. Myocardial infarction in the rat: Infarct size, Myocyte hypertrophy, and cappilary growth. Circ Res (1986) $58: 26-37$.

Anzano MA, Roberts AB, Meyers CA, Komoriya A, Lamb LC, Smith JM, Sporn $M B$. Synergistic action between two classes of transforming growth factors from murine sarcoma cells. Br J Cancer (1982) 42:4776 4778.

Arai $M$, Matsui $H$, Periasamy $M$. Sarcoplasmic reliculum gene expression in cardiac hypertrophy and heart failure. Circ Res (1994) 74:555-564.

Assoian RK, Komoriya A, Meyers CA, Miller DM, Sporn MB. Transforming growth factor-beta in human platelets. J Biol Chem (1983) 258:7155-7160.

Baker KM, Chernin MI, Wixson SK, Aceto JF. Renin-angiotensin system involvement in pressure-overload cardiac hypertrophy in rats. Am J Physiol (1990) 259:H324-H1332.

de la Bastie D, Levitski D, Rappaport L, Mercadier JJ, Marotte F, Wisnewsky C, Brovkovich V. Schwartz K, Lompre AM. Function of sarcoplasmic reticulum and expression of its $\mathrm{Ca} 2+$-ATPase gene in pressure overlaad-induced cardiac hypertrophy in the rat. Circ Res (1990) 66:554-564.

Battersby S, Anderson TJ. Myofibroblast activity of radial scars. J Pathol (1985) $147: 33-40$.

Baur PS Jr, Parks DH, Hudson JD. Epithelial mediated wound contraction in experimental wounds--the purse-string effect. J Trauma (1984) 24:713-720.

Bernotat-Danielowski S, Sharma HS, Schott RJ, Schaper W. Generation and localisation of monoclonal antibodies against fibroblast growth factor in ischemic collateralised porcine myocardium. Cardiovasc Res (1993) 27:12201228.

Betz P, Nerlich A, Tubel J, Penning R, Eisenmenger W. Localization of tenascin in human skin wounds, an immunohistochemical study. Int J Legal Med (1993) $105: 325-328$.

Bikkina $M$, Larson MG, Levy $D$. Asymptomatic ventricular arrhythmias and mortality risk in subjects with left ventricular hypertrophy. $J$ Am Coll Cardiol (1993) 22:1111-1116.

Bishop JE, Greenbaum R, Gibson DG, Yacoub M, Laurent GJ. Enhanced deposition of predominantly type I collagen in myocardial disease. J Mol Cell Cardiol (1990) 22:1157-1165.

Borg TK, Ranson WF, Moshlehy FA, Caulfield JB. Structural basis of ventricular stiffness. Lab Invest (1981) 44:49-50. 
Bouchardy $B$, Majno $G$. Histopathology of early myocardial infarcts. A new approach. Am J Pathol (1974) 74:301-330.

Bouvagnet $\mathrm{P}$, Mairhofer H, Leger IOC, Puech $\mathrm{P}$, Leger JJ. Distribution pattern of $\alpha$ and $\beta$ myosin in normal and diseased human ventricular myocardium. Basic Res Cardiol (1989) 84:91-102.

Braunwald E. Hypertrophic cardiomyopathy: continued progress. N Engl I Med (1989) $320: 800$.

Braunwald $E$, Grossmann W. Clinical aspects of heart failure. In: Braunwald $E$ (Ed.). Heart disease; a textbook of cardiovascular medicine (1992) (4th ed., Vol. 1, pp. 444-463). Philadelphia, W.B. Saunders Company.

Brilla CG, Pick R, Lip B, Janicki JS, Weber KT. Remodeling in the rat right and left ventricles in experimental hypertension. Circulation (1990) Res, 67:13551364.

Brilla CG, Reams GP, Maisch B, Weber KT. Renin-angiotensin system and myocardial fibrosis in hypertension: regulation of the myocardial collagen matrix. Eur Heart J (1993) 14 Suppl J:57-61.

Brilla CG, Zhou G, Matsubara L, Weber KT. Collagen metabolism in cultured adult cardiac fibroblasts: a response to angiotensin and aldosterone. J Moll Cell Cardiol (1994) :in press.

Carre F, Rannou F, Sainte-Beuve C, Chevalier B, Moalic JM, Swynghedauw B, Charlemagne D. Arrhythmogenicity of the hypertrophied and senescent heart and relationship to membrane proteins involved in the altered calcium handling. Cardiovase Res (1993) 27:1784-1789.

Carroll EP, Janicki JS, Pick R, Weber KT. Myocardial stiffness and reparative fibrosis following coronary embolisation in the rat. Cardiovase Res (1989) 23:655-661.

Caspari PG, Newcomb M, Gibson K, Harris P. Collagen in the normal and hypertrophied human ventricle. Cardiovase Res (1977) 11:554-558.

Casscells W, Kimura H, Sanchez JA, Yu Z-X, Ferrans VJ. Immunohistochemical study of fibronectin in experimental myocardial infarction. Am $J$ Pathol (1990) 137:801-810.

Chakraborty $A$, Eghbali $M$. Collagenase activity in the normal rat myocardium: an imnunohistochemical method. Histochem (1989) 92:391-396.

Chapman D, Weber $\mathbb{K T}$, Eghbali M. Regulation of fibrillar collagen types I and III and basement membrane type IV collagen gene expression in pressure overloaded rat myocardium. Circ Res (1990) 67:787-794.

Cleutjens JPM, Kandala JC, Guntaka RV, Weber KT. Regulation of collagen degradation in the rat myocardium after infarction. I Mol Cell Cardiol (1995a) in press.

Cleutjens JPM, Verluyten MJA, Smits JFM, Daemen MJAP. Collagen remodeling after myocardial infarction in the rat heart. Am J Pathol (1995b) in press.

Codd MB, Sugrue DD, Gersh BJ, Melton LJ. III: Epidemiology of idiopathic dilated and hypertrophic cardiomyopathy. Circulation (1989) 80:564-569.

Cohn JN, Archibald DG, Ziesche S. Effects of vasodilator therapy on mortality in chronic congestive heart failure: Results of a Veterans Administration Cooperative Study. N Engl J Med (1986) 314:1547-1554. 
Cohn $N_{\text {s }}$ Johnson $G$, Ziesche $S$. A comparison of enalapril with hydralazineisosorbide dinitrate in the treatment of chronic congestive herat failure. N Engl J Med (1991) 325:303-310.

Contard F, Koteliansky V, Marotte F, Dubus I, Rappaport L, Samuel JL. Specific alterations in the distribution of extracellular matrix components within rat myocardium during the development of pressure overload. Lab Invest (1991) 64:65-75.

Corrin WJ, Morad ES, Murakami $T$. The relationship of afterload to ejection performance in chronic mitral regurgitation. Circulation (1987) 76.59-66.

Crawford DC, Chobanian AV, Brecher P. Angiotensin II induces fibronectin expression associated with cardiac fibrosis in the rat. Circ Res (1994) 74:727. 739.

Cruickshank JM. Clinical importance of coronary perfusion pressure in the hypertensive patient with left ventricular hypertrophy. Cardiology (1992) 81:283-290.

Daemen MJAP, Lombardi DM, Bosman FT, Schwartz SM. Angiotensin II induces smooth muscle cell proliferation in the normal and injured rat arterial wall. Circ Res (1991) 68:450-456.

Darby 1, Skalli O, Gabbiani G. Alpha-smooth muscle actin is transiently expressed by myofibroblasts during experimental wound healing. Lab Invest (1990) $63: 21-29$.

Dausse E, Schwartz K. Genetic heterogeneity of familial hypertrophic cardiomyopathy. Neuromuscul Disord (1993) 3:483-486.

De Larco JE, Todaro GJ. Growth factors from murin sarcoma virus transformed cells. Proc Natl Acad Sci USA (1978) 75:4001-4005.

Desmouliere A, Rubbia-Brandt L, Grau G, Gabbiani G. Heparin induces alphasmooth muscle actin expression in cultured fibroblasts and in granulation tissue myofibroblasts. Lab Invest (1992) 67:716-726.

Desmouliere A, Geinoz A, Gabbiani F, Gabbiani G. Transforming growth factorbeta 1 induces alpha-smooth muscle actin expression in granulation tissue myofibroblasts and in quiescent and growing cultered fibroblasts. $\mathbf{J}$ Cell Biol (1993) 122:103-111.

Deutscher S, Rockette HE, Krishnaswami V. Diabetes and hypercholesterolemia among patients with calcific aortic stenosis. J Chron Dis (1984) 37:407-415.

Doering CW, Jalil JE, Janicki JS, Pick R, Aghili S, Abrahams C, Weber KT. Collagen neiwork remodeling and diastolic stiffness of the rat left ventricle with pressure overload hypertrophy. Cardiovase Res (1988) 22:686-695.

Drexler $H$, Banhardt $U$, Meinertz $T$, Wollschlager $H$, Lehmann $M$, Just $H$. Contrasting peripheral short-term and long-term effects of converting enzyme inhibition in patients with congestive heart failure. A double blind placebocontroled trial. Circulation (1989) 79:491-502.

Ebner R, Chen RH, Lawler $S$, Zioncheck T, Derynck R. Determination of type I receptor specificity by the type II receptors for TGF $\beta$ or activin. Science (1993) 262:900-902 .

Eghbali M. Cardiac fibroblasts: function, regulation of gene expression, and phenotypic modulation. Basic Res Cardiol (1992) 87 Suppl 2:183-189. 
Eghbali M, Blumenfeld OO, Seifter S, Buttrick PM, Leinwand LA, Robinson TF, Zern MA, Giambrone MA. Localization of types I, III and IV collagen mRNAs in rat heart cells by in situ hybridization. I Mol Cell Cardiol (1989a) $21: 103-113$.

Eghbali $M$, Eghbali $M$, Robinson $T F$, Seifter $S$, Blumenfeld $O O$. Collagen accumulation in heart ventricles as a function of growth and aging. Cardiovasc Res (1989b) 23:723-729.

Endo W. Calcium release from the sarcoplasmic reticulum. Physiol Rev (1977) 57:71-108.

Faber M, Wewer UM, Berthelsen JG, Liotta LA, Albreditsen R. Laminin production by human endometrial stromal cells relates to the cyclic and pathologic state of the endometrium. Am J Pathol (1986) 124:384-398.

Feldman AM, Ray PE, Sillan CM, Mercer JA, Minobe W, Bristow MR. Selective gene expression in failing human heart. Quantification of steady-state levels of messenger RNA in endomyocardial biopsies using the polymerase chain reaction. Circulation (1991) 83:1866-1872.

ffrench-Constant $C$, van de Water $L$, Dvorak HF, Hynes RO. Reappearance of an embryonic pattern of fibronectin splicing during wound healing in the adult rat. J Cell Biol (1989) 109:903-914.

Filip DA, Radu A, Simionescu M. Interstitial cells of the heart valves possess characteristics similar to smooth muscle cells. Circ Res (1986) 59:310-320.

Fowler NO. Hypertrophic cardiomyopathy. In: Fowler NO (Ed.) "Diagnosis of heart disease (1991) (1st ed., pp. 256-267). New York, Springer-Verlag.

Frohlich ED, Apstein C, Chobanian AV, Devereux RB, Dustan HP, Dzau V, Fauad-Tarazi F, Horan MJ, Marcus M, Massie B, Pfeffer MA, Re RN, Roccella EJ, Savage D, Shub C. The heart in thypertension. N Engl J Med (1992) 327:998-1008.

Frolik CA, Dart LL, Meyers CA, Smith DM, Spern MB. Purification and initial characterization of a type beta Transforming growth factor from human placenta. Proc Natl Acad Sci USA (1983) 80:3676-3680.

Gabbiani G, Ryan GB, Majno G. Presence of modlified fibroblasts in granulation tissue and their possible role in wound contraction. Experientia (1971) 27:549-550.

Gabbiani $G$, Kocher $O$, Bloom W, Vandekerckhove J, Weber K. Actin expression in smooth muscle cells of rat aortic intimal thickening, human atherosclerotic plaque and cultured rat aortic media. J Clin Invest (1984) 73:148-152.

Geisterfer-Lowerance AA, Kass S, Tanigawa G, Vosberg HP, McKenna W, Seidman CE. Seidman JG. A molecular basis for familial hypertrophic cardiomyopathy: a beta cardiac myosin heawy chain gene missense mutation. Cell (1990) 62:999-1006.

Grajek S, Lesiak M, Pyda M, Zajac M, Paradowski S, Kazmarek E. Hypertrophy or hyperplasia in cardiac muscle. Postmortem human morphometric study. Eur Heart J (1993) 14:40-47.

Guarda E, Katwa LC, Myers PR, Tyagi SC, Weber KT. Effects of endothelins on collagen turnover in cardiac fibroblasts. Cardiovasc Res (1993a) 27:21302134. 
Guarda E, Myers PR, Brilla CG, Tyagi SC, Weber KT. Endothelial cell induced modulation of cardiac fibroblast collagen metabolism. Cardiovasc Res (1993b) $27: 1004-1008$.

Gutman A, Kornblitt AR. Identification of a third region of cell-specific alternative splicing in human fibronectin mRNA. Proc Natl Acad Sci USA (1987) 84:7179.7182.

Hada $Y$, Sakamoto $T$, Amano $K$, el al. Prevalance of hypertrophic cardiomyopathy in a population of adult japanese workers as detected by echocardiographic screening. Am I Cardiol (1987) 59:183.

Hammond IW, Devereux RB, Alderman MH, et al. The prevalence and correlates of echocardiographic left ventricular hypertrophy among employed patients with uncomplicated hypertension. J Am Coll Cardiol (1986) 7:639-650.

Hashimoto $Y$, Oniki T, Kaneko E, Hata A, Matsumura A, Kobayashi T, Numano F. Concentric left ventricular hypertrophy in patients with Takayasu arteriitis. Angiology (1993) 44:883-888.

Havenith MG, Cleutjens JPM, Beek C, v.d. Linden E, De Goeij AFPM, Bosman FT. Human specific anti-type IV collagen monoclonal antibody, characterisation and immunohistochernical application. Histochem (1987) $87: 123-128$.

Hengstenberg C. Schwartz K. Molecular genetics of familial hypertrophic cardiomyopathy. I Mol Cell Cardiol (1994) 26:3-10.

Hengstenberg C, Carrier L, Schwartz K, Maisch B. Clinical and genetical heterogeneity of familial hypertrophic cardiomyopathy. Herz (1994) 19:84-90.

Hirzel HO, Tuchschmid CR, Schneider J, Krayenbuehl HP, Schaub MC. Relationship between myosin isoenzyme composition, hemodynamics and myocardial structure in variuos forms of human cardiac hypertrophy. Circ Res (1985) 57:729-740.

Ho KK, Pinsky JL, Kannel WB, Levy D. The epidemiology of heart failure: the Framingham Study. J Am Coll Cardiol (1993) 22:6A-13A.

Huysman JA, Vliegen HW, Van-der-Laarse A, Eulderink F. Changes in nonmyocyte tissue composition associated with pressure overload of hypertrophic human hearts. Pathol Res Pract (1989) 184:577-581.

Ibrahim SN, Lightner VA, Ventimiglia JB, Ibrahim GK, Walther GK, Bigner DD, Humplarey PA. Tenascin expression in prostatic hyperplasia, intraepithelial neoplasia, and carcinoma. Hum Pathol (1993) 24:982-989.

Ignotz RA, Massague J. Transforming growth factor-beta stimulates the expression of fibronectin and collagen and their incorporation into the extracellular matrix. J Biol Chem (1986) 261:4337-4345.

Imamura T, McDermott PJ, Kent RL, Nagatsu M, Cooper G, Carabello BA. Acute changes in myosin heavy chain synthesis rate in pressure versus volume overload. Circ Res (1994) 75:418-425.

Iwai N, Yamano Y, Chaki S, Konishi F, Bardhan S, Tibbetts C, Sasaki K, Hasegawa $M$, Matsuda $Y$, Inagami $T$. Rat angiotensin II receptor: cDNA sequence and regulation of the gene expression. Biochem Biophys Res Commun (1991) 177:299-304.

Izumi T, Yamazoe M, Shibata A. Three-dimensional characteristics of the 
intramyocardial wasculature of hypertrophied human hearts. I Mol Cell Cardiol (1984) 16:449-457.

Jarcho JA, McKenna W, Pare JA, Solomon SD, Holcombe RF, Dickie S, Levi $T$,

Donis-Keller H, Seidman JG, Seidman CE. Mapping a gene for familial hypertrophic cardiomyopathy to chromosome 14qL. N Engl J Med (1989) $321: 1372-1378$.

Jaskiewicz K, Chasen MR, Robson SC. Differential expression of extracellular matrix proteins and intergrins in hepatocellular carcinoma and chronic liver disease. Anticancer Res (1993) 13:2229-2237.

Johnson CM, Hanson MN, Helgeson SC. Porcine cardiac valvular subendothelial cells in culture: cell isolation and growth characteristics. J Mol Cell Cardiol (1987) 19:1185-1193.

Juhasz I, Murphy GF, Yan HC, Herlyn M, Albelda SM. Regulation of extracellular matrix proteins and integrin cell substratum adhesion receptors on epithelium during cutaneous human woundhealing in vivo. Am J Pathol (1993) 143:1.458-1469.

Kajstura I, Zhang X, Reiss $K$, Szoke E, Li P, Lagrasta C, Cheng W, Darzynkiewicz Z, Olivetti G, Anversa P. Myocyte cellular hyperplasia and myocyte cellular hypertrophy contribute to chronic ventricular remodeling in coronary artery narrowing-induced cardiomyopathy in rats. Circ Res (1994) $74: 383-400$.

Kannel WB, Belanger AJ. Epidemiology of heart failure. Am Heart J (1991) 121:951-957.

Kannel WB, Cupples A. Epidemiology and risk profile of cardiac failure. Cardiovasc Drugs Ther (1988) 2:387-395.

Kannel WB, Gagnon DR, Cupples LA. Epidemiology of sudden coronary death: population at risk. Can J Cardiol (1990) 6:439-444.

Kanno S, Fukuda $Y$. Fibronectin and tenascin in rat tracheal wound healing and their relation to cell proliferation. Pathol Int (1994) 44:96-106.

Katwa LC, Guarda E, Weber KT. Endothelin receptors in cultured adult rat cardiac fibroblasts. Cardiovasc Res (1993) 27:2125-2129.

Katz AM. Angiotensin II: hemodynamic regulator or growth factor? J Mol Cell Cardiol (1990a) 22:739-747.

Katz AM. The heart in congestive failure. Cardioscience (1990b) 1:3-6.

Kennedy JW, Twiss RD, Blackmon JR. Quantitative angiography III:Relationshïps of left ventricular pressure volume and mass in aortic valve disease. Circulation (1968) 38:838-844.

Kerr GS, Hallahan CW, Giordano J, Leavitt RY, Fauci AS, Rottem M, Hoffman GS. Takayasu arteritis. Ann Intern Med (1994) 120:919-929.

Knowlton AA, Connely CM, Romo GM, Mamuya W. Apstein CS, Brecher P. Rapid expression of fibronectin in the rabbit heart after myocardial infarction with and without reperfusion. J Clin Invest (1992) 89:1060-1068.

Komuro I, Kurabayashi M, Shibazaki Y, Takaku F, Yazaki Y. Molecular cloning and characterization of a $\mathrm{Ca} 2+\mathrm{Mg} 2+$-dependant adenosine triphosphate from rat cardiac sarcoplasmic reticulum: regulation of its expression by pressure overload and development stage. J Clin Invest (1989) 83:1102-1108. 
Lazarous DF, Scheinowitz M, Shou M, Hodge E, Rajanayagam MAS, Hunsberger S, Robison G, Stiber JA, Correa R, Epstein SE, Unger EF. Effects of chronic systemic administration of basic Fibroblast Growth Factor on collateral development in the canine heart. Circulation (1995) 91:145-153.

Lefer AM, Lefer DJ. Pharmacology of the endothehium in ischemia-reperfusion and circulatory shock. Annu Rev Pharmacol Toxicol (1993) 33:71-90.

Lefer AM, Tsao PS, Ma XL, Sampath TK. Anti-ischaemic and endothelial protective actions of recombinant human osteogenic protein (hOP-1). J Mol Cell Cardiol (1992) 24:585-593.

Lenkilewicz JE, Davies MJ, Rosen D. Collagen in human myocardium as a function of age. Cardiovasc Res (1972) 6:549-555.

Leslie KO, Taatjes DJ, Schwarz J, won Turkovich M, Low RB. Cardiac myofibroblasts express alpha smooth muscle actin during right ventricular pressure overload in the rabbit. Am J Pathol (1991) 139:207-216.

Lester W, Rosenthal A, Granton B, Gotlieb AI. Porcine mitralic valve interstitial cells in culture. Lab Invest (1988) 59:710-719.

Levitskí D, de la Bastie D. Schwartz K, Lompre AM. ATPase and function of sarcoplasmic reticulum during cardiac hypertrophy. Am J Physiol (1991) 261 (suppl):23-26.

Levy D. Left ventricular hypertrophy. Epidemiological insights from the Framingham Heart Study. Drugs (1988) 35 Suppl 5:1-5.

Levy D. Clinical significance of left ventricular hypertrophy: insights from the Framingham Study. J Cardiovase Pharmacol (1991) 17 Suppl 2:S1-S6.

Levy D, Savage DD, Garrison RJ, Anderson KM, Kannel WB, Castelli WP. Echocardiographic criteria for left ventricular hypertrophy: The Framingham Heart Study. Am J Cardiol (1987) 59:956-960.

Levy D, Anderson KM, Savage DD, Kannel WB, Christiansen JC, Castelli WP. Echocardiographically detected left ventricular hypertrophy: prevalence and risk factors. The Framingham Heart Study, Ann Intern Med (1988) 108:7-13.

Levy D, Garrison RJ', Savage DD, Kannel WB, Castelli WP. Prognostic implications of echoacrdiographically determined left ventricular mass in the Framingham heart study. N Engl J Med (1990a) 322:1561-1566.

Levy D, Wilson PW, Anderson KM, Castelli WP. Stratifying the patient at risk from coronary heart disease: new insights from the Framingham heart study. Am Heart J (1990b) 119:712-717.

Lindner V, Reidy MA. Expression of basic fibroblast growth factor and its receptor by smooth muscle cells and endothelium in injured rat arteries. An en face study. Circ Res (1993) 73:589-595.

Lipke DW, McCarthy KJ, Elton TS, Arcot SS, Oparil S, Couchman JR. Coarctation induces alterations in basement membranes in the cardiovascular system. Hypertension (1993) 22:743-753.

Long CS, Hartogensis WE, Simpson PC. Beta-adrenergic stimulation of cardiac non-myocytes augments the growth-promoting activity of non-myocyte conditioned medium. J Mol Cell Cardiol (1993) 25:915-925.

Lopez JJ, Lorell BH, Ingelfinger JR, Weinberg EO, Schunkert H, Diamant D, Tang S-S. Distribution and function of cardiac angiotensin AT1- and AT2- 
receptor subtypes in hypertrophied rat hearts. Am J Physiol (1994) 267:H844H852.

Lopez-Casillas F, Payne HM, Andreas JL, Massague T. Betaglycan can act as binding and GAG attachment sites. J Cell Biol (1994) $124: 557-568$.

Loud A V, Anversa P, Giacomelli F, Wiener J. Absolute morphometric studiy of myocardial hypertrophy in experimental hypertension. $\mathrm{I}$. Determination of myocyte size. Lab Invest (1978) 38:586-595.

Luomanen $M$, Virtanen $I$. Distribution of tenascin in healing incision, excision and laser wounds. J Oral Pathol Med (1993) 22:41-45.

MacLellan WR, Brand T, Schneider MD. Transforming growth factor-beta in cardiac ontogeny and adaptation. Circ Res (1993) 73:783-791.

Mamuya WS, Brecher P. Fibronectin expression in the normal and hypertrophic rat heart. J Clin Invest (1992) 89:392-401.

Maron BJ, Bonow RO, Cannon RO. Hypertrophic cardiomyopathy: interrelation of clinical manifestation, pathofysiology and thearapy. N Engl J Med (1987) $316: 780$ and 844 .

Matsumoto K, Saga Y, Ikemura T, Sakakura T, Chiquet-Ehrismann R. The distribution of tenascin-X is distinct and often reciprocal to that of tenascin-C. J Cell Biol (1994) 125:483-493.

Matsuoka LY, Uitto J, Wortsman J, Abergel RP, Dietrich J. Ultrastructural characteristics of keloid fibroblasts. Am J Dermatopathol (1988) 10:505-508.

McGormick RJ, Musch TI, Bergman BC, Thomas DP. Regional differences in LV collagen accumulation and mature crosslinking after myocardial infarction in rats. Am J Physiol (1994) 266:H354-H359.

Meiners S, Marone M, Rittenhouse JL, Geller HM. Regulation of astrocytic tenascin by basic fibroblast growth factor. Dev Biol (1993) 160:480-493.

Mercadier JJ, Zongazo MA, Wisnewsky C, Butler-Brown G, Gros D, Carayon A, Schwartz K. Atrial natriuretic factor messenger ribonucleic acid and peptide in the human heart during ontogenic development. Biochem Biophys Res Comm (1989) 159:777-782.

Michel JB, Salzmann JL, Ossondo-Nlom M, Bruneval P, Barres D, Camilleri JP. Morphometric analysis of collagen network and plasma perfused capillary bed in the myocardium of rats during evolution of cardiac hypertrophy. Basic Res Cardiol (1986) 81:142-154.

Morrow AG, Braunwald E. Functional aortic stenosis: a malformation characterized by resitance to left ventricular outflow without anatomic obstruction. Circulation (1959) 20:181.

Murphy TJ, Alexander RW, Griendling KK, Runge MS, Bernstein KE. Isolation of a cDNA encoding the vascular type-I angiotensin II receptor. Nature (1991) $351: 233-236$.

Newman TJ, Maskin CS, Dennick LG. Effects of captopril on survival in patients with heart failure. Am J Med (1988) 84:140-149.

Nishi H, Kimura A, Harada H, Adachi K, Koga Y, Sasazuki T, Toshima H. Possible gene dose effect of a mutant cardiac beta-myosin heavy chain gene on the clinical expression of familial hypertrophic cardiomyopathy. Biochem Biophys Res Commun (1994) 200:549-556. 
Nishida M, Springhorn JP, Kelly RA, Smith TW. Cell-cell signaling between adult rat ventricular myocytes and cardiac microvascular endothelial cells in heterotypic primary culture. J Clin Invest (1993) 91:1934-1941.

Nwasokwa $O$, Camesas A, Weg I, Bodenheimer MM. Differences in left ventricular adaptation to chronic mitral and aortic regurgitation. Chest (1989) 95:106-112.

Oh $\mathbb{E}_{\text {" Pierschbacher } M}$ Ruoslati $E$. Deposition of plasma fibronectin in tissue. Proc Nat Acad Sci USA (1981) 78:3218-3221.

Ojamaa K, Petrie JF, Balkman C, Hong C, Klein I. Posttranscriptional modification of myosin heavy-chain gene expression in the hypertrophied rat myocardium. Proc Natl Acad Sci U S A (1994) 91:3468-3472.

Okada Y, Watanabe S, Nakanishi I, Kishi J, Hayakawa T, Watorek W, Travis J, Nagase H. Inactivation of tissue inhibitor of metalloproteinases by neutrophil elastase and other serine proteinases. FEBS Lett (1988) 229:157-160.

Olivetti $G$, Ricci $R$, Anversa P. Hyperplasia of myocyte nuclei in long-term cardiac hypertrophy in rats. J Clin Invest (1987) 80:1818-1821.

Overall $\mathrm{CM}$, Wrana $\mathrm{JL}$, Sodek J. Independent regulation of collagenase, $72 \mathrm{kDa}-$ progelatinase, and metalloproteinase inhibitor (TIMP) expression in human fibroblasts by transforming growth factor- $\beta$. J Biol Chem (1989) 264:18601869.

Padua RR, Kardami E. Increased basic fibroblast growth factor (bFGF) accumulation and distinct patterns of localization in isoproterenol-induced cardiomyocyte injury. Growth Factors (1993) 8:291-306.

Panidis IP, Segal BL. Aortic valve disease in elderly. In: Frankl WS, Brest AN (Eds.), Cardiovascular clinics. Valvular heart disease: comprehensive evaluation and management (1986) (1st ed., pp. 289-312). Philadelphia, F.A. Davis.

Passier RCJJ, Smits JFM, Verluyten MJA, Struder R, Drexler $H$, Daemen MJAP. Activation of angiotensin-converting-enzyme expression in the infarct zone following myocardial infarction. Am J Physiol (1995) in press.

Passik CS, Ackermann DM, Pluth JR, Edwards JE. Temporal changes in teh cause of aortic stenosis. A surgical pathological study of 646 cases. Mayo Clin Proc (1987) 62:119-127.

Paul M, Wagner J, Dzau VJ. Gene expression of the renin-angiotensin system in human tissues. Quantitative analysis by the polymerase chain reaction. I Clin Invest (1993) 91:2058-2064.

Pearlman ES, Weber KT, Janicki JS, Pietra GG, Fishman AP. Muscle fiber orientation and connective tissue content in the hypertrophied human heart. Lab Invest (1982) 46:158-164.

Pearson CA, Pearson D, Shibahara S, Hofsteenge J, Chiquet-Ehrismann R. Tenascin: cDNA cloning and induction by TGF- $\beta$. Embo J (1988) 7:26772981.

Pfeffer MA, Braunwald E. Ventricular remodelling after myocardial infarction. Experimental observations and clinical implications. Circulation (1990) $81: 1161-1172$.

Pick R, Janicki IS, Weber KT. Myocardial fibrosis in nonhuman primate with 
pressure overload hypertrophy. Am J Pathol (1989a) 135:771-781.

Pick R, Janicki J, Weber KT. Myocardial fibrosis in nonhuman primate with pressure overload hypertrophy. Am J Pathol (1989b) 135:771-781.

Pilatte $Y$, Bignon J, Lambre CR. Lysosomal and cytosolic sialidases in rabbit alveolar macrophages: demonstration of increased lysosomal activation after in vivo activation with bacillus Calmette-Guerin. Biochim Biophys Acta (1987) $923: 150-155$.

Polikar R, Burger AG, Scherrer U, Nicod P. The thyroid and the heart. Circulation (1993) $87: 1435-1441$.

Pourreau-Schneider N, Ahmed A, Soudry M, Jacquemier J, Kopp F, Franquin JC, Martin PM. Helium-neon laser treatment transforms fibroblasts into myofibroblasts. Am J Pathol (1990) 137:171-178.

Rakusan $K_{*}$ Flanagan MF, Geva $T$, Southern $J$, Van Praagh R. Morpliometry of human coronary capillaries during normal growth and the effect of age in left ventricular pressure-overload hypertrophy. Circulation (1992) 86:38-46.

Rapaport E. Natural history of aortic and mitral valve disease. Am J Cardiol (1975) $35: 221-228$.

Ratajska A, Campbell SE, Sun Y, Weber KT. Angiotensin II associated cardiac myocyte necrosis: role of adrenal catecholamines. Cardiovasc Res (1994) 28:684-690.

Re R. The myocardial intracellular renin-angiotensin system. Am J Cardiol (1987) 59:56-58.

Reitsma JB. Mortaliteit en morbiditeit van hart- en vaatziekten bij vrouwen. Hart Bulletin (1995) 26:5-11.

Roberts $\mathrm{AB}$, Sporn MB. The Transforming Growth Factors- $\beta$ s. In: Cummins $P$ (Ed.), Growthfactors and cardiovascular system (1993) (1st ed., pp. 419-472). London, Kluwer Academic Publishers.

Roberts AB, Anzano MA, Lamb LC, Smith JM, Sporn MB. New class of transforming growth factors potentiated by epidermal growth factor. Proc Natl Acad Sci USA (1981) 78:5339-5343.

Roberts AB, Frolik CA, Anzano MA, Sporn MB. Transforming growth factors from neoplastic and non-neoplastic tissues. Fed Proc (1983) 42:2621-2626.

Roberts AB, Roche NS, Winokur TS, Burmester JK, Sporn MB. Role of transforming growth factor-beta in maintenance of function of cultured neonatal cardiac myocytes. Autocrine action and reversal of damaging effects of interleukin-1. J Clin Invest (1992a) 90:2056-2062.

Roberts AB, Vodovotz Y, Roche NS, Sporn MB, Nathan CF. Role of nitric oxide in antagonistic effects of transforming growth factor-beta and interleukin- 1 beta on the beating rate of cultured cardiac myocytes. Mol Endocrinol (1992b) $6: 1921-1930$.

Roberts WC. Valvular, subvalvular and suprawalvular aortic stenosis. Morphological features. Cardiovasc Clin (1973) 5:97-103.

Robinson TF, Geraci MA, Sonnenblick EH, Factor SM. Coiled perimysial fibers of papillary muscle in rat heart: morphology, distribution, and changes in configuration. Circ Res (1988) 63:577-592.

Rodeheffer RJ, Jacobsen SJ, Gersh BJ, Kottke TE, McCann HA, Bailey KR, 
Ballard DI. The incidence and prevalence of congestive heart failure in Rochester, Minnisota. Mayo Clin Proc (1993) 68:1143-1150.

Ross $J$, Janero DR, Hreniuk D. Identification and biochemical characterization of a heartmuscle cell transforming growth factor betall receptor. Biochem Pharmacol (1993a) 46.511-516.

Ross J, Janero DR, Hreniuk D. Identification and molecular characterization of a high-affinity cardiomyocyte transforming growth factor-beta 2 receptor. FEBS Lett (19936) $320 / 229234$.

Rossil $P$, Karsenty $G$, Roberts AB, Roche NS, Sporn MB, de Crombrugghe B. A nuclear factor 1 binding site mediates the transeriptional activation of a type I collagen promotor by transforming growth factor- $\beta$. Cell (1988) 52:405-414.

Sadoshima J-I, Izumo S. Molecular charaterisation of angiotensin II-induced bypertrophy of cardiac myocytes and hyperplasia of cardiac fibroblasts. Circ Res (1994) 73:413-423.

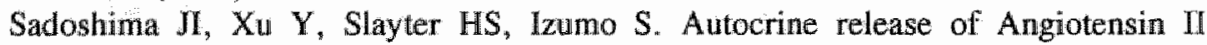
mediates stretch-induced hypertrophy of cardiac myocytes in vitro. Cell (1993) $75: 977-984$.

Samuel JL, Barrieux A, Dufour S, Dubus I, Contard F, Koteliansky V, Farhadian F. Marote F, Thiery J-P, Rappaport $L$. Accumulation of fetal Fibronectin mRNA during the development of rat cardiac bypertrophy induced by pressure overload. J Clin Invest (1991) 88:1737-1746.

Savage DD, Levy D, Dannenberg AL, Garrison RJ, Castelli WP. Association of echocardiographic left ventricular mass with body size, blood pressure and physical activity (Framingham study). Am J Cardiol (1990) 65:371-376.

Schaper $J$, Schaper $W$. Ultrastructural correlates of reduced cardiac function in human heart disease. Eur Heart $J$ (1983) 4:35-42.

Schiaffino S, Samuel JL, Sassoon D, Lompre AM, Garner I, Marotte F, Buckingham M, Rappaport L, Schwartz K. Nonsynchronous accumulation of alpha-skeletal actin and beta-myosin heavy chain mRNAs during early stages of pressure-overload-induced cardiac hypertrophy demonstrated by in situ hybridization. Circ Res (1989) 64:937-948.

Schoemaker RG, Smits JF. Systolic time intervals as indicators for cardiac function in rat models for heart failure. Eur Heart J (1990) 11 Suppl I: 114-123.

Schoemaker RG, Debets IJM, Struyker-Boudier HAJ, Smits JFM. Delayed but not immediate captopril therapy improves cardiac function in conscious rats. J Moll Cell Cardiol (1991) 23:187-197.

Schunkert H, Dxau VJ, Tang SS, Hirsch AT, Apstein CS, Lorell BH. Increased rat cardiac angiotensin converting enzyme activity and mRNA expression in pressure overload left ventricular hypertrophy. Effects on coronary resustance, contractility, and relaxation. J Clin Invest (1990) 86:1913-1920.

Schwartz K, De la Bastie D, Bouveret P, Oliviero P, Alonso $S$, Buckingham M. Alpha-skeletal musle actin mRNA accumulates in hypertrophied adult rat hearts. Circ Res (1986) 59:551-555.

Schwartz K, Carrier L, Chassagne C, Wisnewsky C, Boheler KR. Regulation of myosin heavy chain and actin isogenes during candiac growth and hypertrophy. Symp Soc Exp Biol (1992) 46:265-272. 
Schwartzbauer JE, Patel RS, Fonda $D$, Hynes $R$. Multiple sites of alternative splicing of the rat fibronectin gene transcript. Eur Mol Biol Organ (1987) 6:2573-2580.

Schwarz F, Flameng W, Schaper J, Hebrlein F. Correllation between myocardial structure and diastolic properties of the heart in chronic aortic valve disease: Effects of corrective surgery. Am J Cardiol (1978) 42:895-903.

Seyedin SM, Thomas TC, Thompson AY, Rosen DM, Piez KA. Purification and characterization of two cartilage inducing factors from demimeralized bone. Proc Natl Acad Sci USA (1985) 82:2267-2271.

Shekhonin BV, Domogatsky SP, Idelson GL, Koteliansky VE. Participance of fibronectin and various collagen types in the formation of fibrous extracellular matrix in cardiosclerosis. J Mol Cell Cardiol (1988) 20:501-508.

Shekhonin BV, Guriev SB, Irgashev SB, Koteliansky VE. Immunofluorescent identification of fibronectin and fibrinogen/fibrin in experimental myocardial infarction. J Moll Cell Cardiol (1990) 22:533-541.

Shikata $N$, Oyaizu $T$, Andachi $H$, Tsubura A. Tenascin expression in normal human adult skin and skin appendage tumours. Virchows Arch B Cel! Pathol (1994) 424:511-516.

Siburian G, Hashimoto $Y$, Numano F. Ventricular arrhythmias in Takayasu arteritis. Int J Cardiol (1993) 40:243-249.

Silver IA, Murrills RJ, Etherington DJ. Microeclectode studies on the acid microenvironment beneath adherent macrophages and osteoclasts. Exp Cell Res (1988) 175:266-276.

Skalli O, Ropraz P, Trzeciak A, Benzonana G, Gillessen D, Gabbiani G. A monoclonal antibody against alpha-smooth muscle actin: a new probe for smooth muscle differentiation. J Cell Biol (1986) 103:2787-2796.

Skalli O, Schurch W, Seemayer T, Lagace R, Montandon D, Pittet B, Gabbiani G. Myofibroblasts from diverse pathologic settings in their content of actin isoforms and intermediate filament proteins. Lab Invest (1989) 60:275-285.

Smits JFM, Cleutjens JPM, van-Krimpen C, Schoemaker RG, Daemen MJAP. Cardiac remodeling in hypertension and following myocardial infarction: effects of arteriolar vasodilators. Basic Res Cardiol (1991) 86 Suppl 1:133139.

Solomon SD, Geisterfer-lowrance AA, Vosberg HP, Hiller G, Jarcho JA, Mitchell AL, Bale AE, Mckenna WJ, et al. A locus for familial hypertrophic cardiomyopathy is closely linked to the cardiac myosin beavy chain genes, CRI-L436, and CRI-L329 on chromosome 14 at q11-q12. Am J Hum Genet (1990a) 47:389-394.

Solomon SD, Jarcho JA, McKenna W, Geisterfer-lowrance A, Germain R, Salerni $R$, Seidman JG, Seidman CE. Familial hypertrophic cardiomyopathy is a genetically heterogeneous disease. J Clin Invest (1990b) 86:993-999.

The SOLVD investigators. Effects of angoitensin converting enzyme inhibitor enalapril on survival in patients with reduced left ventricular ejection fraction and congestive heart failure. N Engl J Med (1991) 325:293-303.

Sottiurai VS, Batson RC. Role of myofibroblasts in pseudointima formation. Surgery (1983) 94:792-801. 
Sporn $M B$, Roberts $A B$. Transforming growth factor-beta: recent progress and new challenges. I Cell Biol (1992) 119:1017-1021.

Stout LC, Boor PJ, Whorton EB Jr. Myofibroblastic proliferation on mitral valve chordae tendineae: a distinctive lesion associated with alcoholic liver disease. Hum Pathol (1988) 19:720-725.

Strickberger SA, Schulman SP, Hutchins GM. Association of Paget's disease of bone with calcific aortic valve disease. Am J Med (1987) 82:953-960.

Studer R, Reinecke $H$, Bilger $J$, Eschenhagen $T$, Bohm M, Hasenfuss $G$, Just $H_{\text {, }}$ Holtz $J$, Drexler $H$. Gene expression of the cardiac $\mathrm{Na}+-\mathrm{Ca} 2+$ exchanger in end-stage human heart fallure. Circ Res (1994) 75:443-453.

Sudoh $\mathrm{T}$, Kangawa $\mathrm{K}$, Minamino $\mathrm{N}$, Matsuo $\mathrm{H}$. A new natriuretic peptide in porcine brain. Nature (1988) 332;78-81.

Sun $Y$, Weber KT. Angiotensin II and aldosterone receptor binding in rat heart and kidney: response to chronic angiotensin II or aldosterone administration. J Lab Clin Med (1993) 122:404-411.

Sun $Y$, Ratajska $A$, Zhou $G$, Weber KT. Angiotensin-converting enzyme and myocardial fibrosis in the rat receiving angiotensin II or aldosterone. $J$ Lab Clin Med (1993) 122:395-403.

Sun Y, Diaz-Arias AA, Weber KT. Angiotensin-converting enzyme, bradykinin, and angiotensin II receptor binding in rat skin, tendon, and heart valves: an in vitro, quantitative autoradiographic study. J Lab Clin Med (1994) 123:372377.

Suzuki J, Matsubara H, Urakami M, Inada M. Rat angiotensin II (type 1A) receptor mRNA regulation and subtype expression in myocardial growth and hypertrophy. Circ Res (1993) 73:439-447.

Swedberg K, Kjekhus J. Effect of enalapril on mortality in congestive heart failure. Follow-up survival data from the CONSENSUS trail. Drugs (1990) 39:49-56.

Tamkun JW, Hynes RO. Plasma fibronectin is produced by hepatocytes. J Bio! Chem (1983) 258:4641-4646.

Tan EM, Hoffren J, Rouda S, Greenbaum S, Fox JW 4th, Moore JH Jr, Dodge GR. Decorin, versican, and biglycan gene expression by keloid and normal dermal fibroblasts: differential regulation by basic fibroblast growth factor. Exp Cell Res (1993) 209:200-207.

Taningawa $G$, Jarcho JA, Kass $S$, Solomon $S D$, Vosberg HP, Seidman JG, Seidman CE. A molecular basis for familial hypertrophic cardiomyopathy: an ajpha/beta cardiac myosin heavy chain hybrid gene. Cell (1990) 62:991-998.

Teerlink JR, Pfeffer JM, Pfeffer MA. Progressive ventricular remodeling in response to diffuse isoproterenol-induced myocardial necrosis in rats. Circ Res (1994) 75:105-113.

Thiemermann $C$, Corder $R$. Is Endothelin-1 the regulator of myofibroblast contraction during woundhealing? Lab Invest (1992) 67:677-679.

Thierfelder L, Watkins H, MacRae C, Lamas R, McKenna W, Vosberg HP, Seidman JG, Seidman CE. Alpha-tropomyosin and cardiac troponin $T$ mutations cause familial hypertrophic cardiomyopathy: a disease of the sarcomere. Cell (1994) 77:701-712.

Tomanek RJ, Wessel TJ, Harrison DG. Capillary growth and geometry during 
long-term hypertension and myocardial hypertrophy in dogs. Am J Physiol (1991) 261:H1011-H1018.

Tomasek JJ, Schultz RJ, Episalla CW, Newinan SA. The cytoskeleton and extracellular matrix of the Dupuytren"s disease "myofibroblast": an immunofluorescence study ofa nonmuscle cell type. J Hand Surg Am. (1986) $11: 365-371$.

Truong LD, Pindur J, Barrios $R$, D'Agati $V$, Lechago J, Suki W, Majesky M. Tenascin is an important component of the glomerular extracellular matrix in normal and pathologic conditions. Kidney Int (1994) 45:201-210.

Tyagi SC, Ratajska A, Weber KT. Myocardial matrix metalloproteinase(s): localization and activation. Mol Cell Biochem (1993) 1.26:49-59.

Unger EF, Banai S, Shou M, Lazarous DF, Jaklitsch MT, Scheinowitz M, Correa $R$, Klingbeil $C$, Epstein SE. Basic fibroblast growth factor enhances myocardial collateral flow in a canine model. Am J Physiol (1994) 266:H1588-H1595.

Vande-Berg JS, Rudolph R, Woodward M. Growth dynamics of cultured myofibroblasts from human breast cancer and nonmalignant contracting tissues. Plast Reconstr Surg (1984) 73:605-618.

van-der-Laarse A, Hollaar L, Vliegen HW, Egas JM, Dijkshoorn NJ, Cornelisse CJ, Bogers AJ, Quaegebeur JM. Myocardial (iso)enzyme activities, DNA concentration and nuclear polyploidy in hearts of patients operated upon for congenitall heart disease, and in normal and hypertrophic adult human hearts at autopsy. Eur J Clin Invest (1989a) 19:192 200.

van-der-Laarse A, Vliegen HW, van-der-Nat KH, Hollaar L, Egas JM, Swier GP, van-den-Broek AJ. Comparison of myocardial changes between pressure induced hypertrophy and normal growth in the rat heart. Cardiovasc Res (1989b) 23:308-314.

van-Krimpen C, Schoemaker RG, Cleutjens JP, Smits JF, Struyker-Boudier HA, Bosman FT, Daemen MJ. Angiotensin I converting enzyme inhibitors and cardiac remodeling. Basic Res Cardiol (1991a) 86 Suppl 1:149-155.

van Krimpen C, Smits JFM, Cleutjens JPM, Debets JJM, Schoenmaker RG, Struyker Boudier HAJ, Bosman FT, Daemen MJAP. DNA synthesis in the non-infarcted cardiac interstitium after left coronary artery ligation in the rat: effects of Captopril. J Mol Cell Cardiol (1991b) 23:1245 1253.

Vartio $T$, Laitinen $L$, Narvanen $O$, Cutolo $M$, Thornell LE, Zardi $L$, Virtanen I. Differential expression of the ED sequence-containing of cellular fibronectin in embryonic and adult human tissues. J Cell Sci (1987) 88:419 430.

Vaziri SM, Larson MG, Benjamin EJ, Levy D. Echocardiographic predictors of nonrheumatic atrial fibrillation. The Framingham Heart Study. Circulation (1994) 89:724-730.

Villari B, Campbell SE, Hess OM, Mall G, Vassalli G, Weber KT, Krayenbuehl HP. Influence of collagen network on left ventricular systolic and diastolic function in aortic valve disease. I Am Coll Cardiol (1993) 22:1477-1484.

Villarreal FJ, Kim NN, Ungab GD, Printz MP, Dillmann WH. Identification of functional angiotensin II receptors on rat cardiac fibroblasts. Circulation (1993) 88:2849-2861. 
Volders PGA, Willems IEMG, Cleutjens JPM, Arends JW, Havenith MG, Daemen MJAP. Interstital collagen is increased in the non-infarcted human myocardium after myocardial infarction. J Mol Cell Cardioll (1993) 25:13171323.

Vosberg HP. Myosin mutations in hypertrophic cardiomyopathy and functional implications. Herz (1994) 19:75-83.

Vracko $R$, Thorning $D$. Contractile cells in rat myocardial scar tissue. Lab Invest (1991) 65:214-227.

Vracko R, Thorning D, Fredrickson RG. Connective tissue cells in healing rat myocardium. A study of cell reactions in rhythmically contracting environment. Am J Pathol (1989) 134:993-1006.

Vracko $R$, Thoming $D$, Frederickson RG. Nerve fibers in human myocardial scars. Hum Pathol (1991) 22:138-146.

Vrucinic-Filipi $N$, Chiquet-Ehrismann $R$. Tenascin function and regulation of expression. Symp Soc Exp Biol (1993) 47:155-162.

Vyalov $S$, Desmouliere a, Gabbiani G. GM-CSF-induced granulation tissue formation: relationships between macrophage and myofibroblast accumulation. Virchows Arch B Cell Pathol (1993) 63:231-239.

Wagenknecht $T$, Grassucci $R$, Frank $\mathbb{J}$, Saito $A$, Inui $M$, Fleischer $S$. Three dimensionall architecture of Calcium channel/foot structure of sarcoplasmic reticulum. Nature (1989) 338:167-170.

Waller BF, Rheumatic and non-rheumatic conditions producing valvular heart disease. In: Frankl WS, Brest AN (Eds.), Cardiovascular clinics. Valvular heart disease: comprehensive evaluation and management (1986) (1st ed., pp. 3-104). Philadelphia, F.A. Davis.

Weber KT. Cardiac interstitium in health and disease; the fibrillar collagen network. J Am Coll Cardiol (1989) 13:1637-1652.

Weber K, Janicki J, Pick R, Abrahams C, Shroff S, Bashey R, Chen R. Collagen in the hypertrophied, pressure overloaded myocardium. Circulation (1988) $75: 140-147$.

Weber KT, Jalil JE, Janicki JS, Pick R. Myocardial collagen remodeling in pressure overload hypertrophy. A case for interstitial heart disease. Am J Hypertens (1989a) 2:931-940.

Weber KT, Pick R, Jalii JE, Janicki JS, Carroll EP. Patterns of myocardial fibrosis. J Mol Cell Cardiol (1989b) 21 Suppl 5:121-131.

Weber KT, Anversa P, Armstrong PW, Brilla C, Burnett JC, Cruickshank JM, Devereux RB, Giles TD, Korsgaard N, Leier C V, Mendelsohn FA, Motz WH, Mulvany MJ, Strauer BE. Remodeling and reparation of the cardiovascular system. J Am Coll Cardiol (1992) 20:3-16.

Weber KT, Sun $Y$, Tyagi SC, Cleutjens JP. Collagen network of the myocardium: function, structural remodeling and regulatory mechanisms. J Mol Cell Cardiol (1994) 26:279-292.

Weber KT, Sun Y, Katwa LC, Cleutjens JPM. Connective tissue: a metabolic entity. J Moll Cell Cardiol (1995) 27:107-120.

Willems IEMG, Havenith MG, De Mey JGR, Daemen MJAP. Alpha smooth muscle actin positive cells in healing human myocardial scars. Am J Pathol 
(1994) 145:868-875.

Winterton SJ, Turner MA, O'Gorman DI, Flores NA, Sheridan DJ. Hypertrophy causes delayed conduction in human and guinea pig myocardium: accentuation during ischaemic perfusion. Cardiowasc Res (1994) 28:47-54.

Yajima M, Numano F, Park YB, Sagar S. Comparative studies of patients with Takayasu arteritis in Japan, Korea and India-comparison of clinical manifestations, angiography and HLA-B antigen. Jpn Circ J (1994) 58:9-14.

Yao J, Eghbali M. Decreased collagen gene expression and absence of fibrosis in thyroid hormone-induced myocardial hypertrophy- response of cardiac fibroblasts to thyroid hormone in vitro. Circ Res (1992) 71:831-839.

Yarom R, Zirkin H, Stammler G, Rose AG. Human coronary microvessels in diabetes and ischemia. Morphometric study of autopsy material. J Pathol (1992) 166:265-270.

Yasue $H$, Yoshimura M, Sumida $H$, Kikuta K, Kugiyama $K$, Michihisha J, Ogawa $H$, Okumura $K$, Mukoyama $m M$, Nakao $K$. Localization and mechanism of secretion of B-type Natriuretic Peptide in comparison with those of A-type Natriuretc Peptide in normal subjects and patients with heart failure. Circulation (1994) 90:195-203.

Yoshida M, Kimura A, Katsuragi K, Numano F, Sasazuki T. DNA typing of HLA B gene in Takayasu's arteritis. Tissue Antigens (1993) 42:87-90.

Zacks S, Rosenthal A, Granton B, Havenith M, Opas M, Gotlieb AI. Characterization of Cobblestone mitral valve interstitial cells. Arch Pathol Lab Med (1991) 115:774-779. 

CHAPTER 2

INCREASED INTERSTITIAL COLLAGEN IN NON-INFARCTED HUMAN MYOCARDIUM AFTER MYOCARDIAL INFARCTION

Volders PG, Willems IEMG, Cleutjens JP, Arends JW, Havenith MG, Daemen MJAP.

J Moll Cell Cardiol 1993 Nov;25(1.1):1317-1323 
We report the changes of interstitial collagen in the human non-infarcted interventricular septum afier a myocardial infarction as well as in hypertrophic human hearts with or without hypertension. The collagen amount was determined with the Sirius Red morphometry technique, which enabled us to perform these studies on routinely processed, paraffin embedded sections.

The collagen amount was significantly increased in the septum of infarct patients as compared to non-infarcted controls $(p<0.001)$. The collagen amount in the septum of the hypertensive hypertrophy group $(H H)$ was significantly increased as compared to the non-hypertensive hypertrophy group $(N H H)(p<0.01)$. The collagen content in the NHH was not significantly different from the controls in the infarct group, while the collagen amount in the HH showed no significant difference to the collagen content in the infarct group.

The results indicate that collagen deposition is increased in the noninfarcted myocardium after a myocardial infarction, as well as in the hypertensive hypertrophied myocardium. The data suggest that the appearance of excessive collagen is not mediated by cardiac hypertrophy per se, but that the underlying cause, infarction or hypertension, is the significant factor.

\section{INTRODUCTION}

The myocardium consists of muscle fibers, blood vessels and a network of connective tissue. This connective tissue plays an important role in maintaining the functional integrity of the myocardium (Eghbali et al., 1989; Bishop et al., 1990). Collagen is the major component of the cardiac interstitium. Recent studies have indicated that the amount, composition and distribution of interstitial collagen determines the stiffness of the heart, which is an important denominator of myocardial function (Doering et al., 1988; Weber et al., 1989). While many reports are available showing an increase in interstitial collagen in experimentally induced pressure overload cardiac hypertrophy (Doering et al., 1988; Pick et al., 1989; Contard et al., 1991), less is known about changes in the interstitial collagen after myocardial infarction. Recent experiments performed in our laboratory indicate that the collagen amount significantly increases in the non-infarcted interven- 
tricular septum and right ventricle after an experimentally indinced myocardial infarction in the rat. We also showed inhibitory effects of the ACE inhibitor captopril on this collagen deposition (Smits et al., 1991; van-Krimpen et al., 1991a), which was associated with negative effects on heart function (Schoemaker \& Smits, 1990).

In this study we report the changes of interstitial collagen in the human non-infarcted interventricular septum after a myocardial infarction and in the interventricular septum of hypertrophic human hearts with or without hypertension. The collagen amount was determined with the Sirius Red morphometry technique, which enabled us to perform these studies on routinely processed, paraffin embedded sections.

\section{MATERIALS AND METHODS}

Myocardial tissue from the interventricular septum was routinely sampled during autopsies performed at the Department of Pathology in the University Hospital of Maastricht, the Netherlands.

Study 1. Collagen content in the non-infarcted interventricular septum of the infarcted myocardium

Two groups of patients were selected, an infarct group and a non-infarct group. The infarct group included 18 patients who suffered from a myocardial infarction, at least 6 weeks before death, with a maximum of 13 years (mean 5.6 years). Only hearts with an transmural infarct in the anterior, posterior or lateral part of the left ventricle were included, while hearts with an interventricular septal infarct were excluded. Infarct localisation was performed by a routinely performed Nitro Blue Tetrazolium stain of a coronal heart slice, followed by routine histological examination of tissue samples of the infarct area and interventricular septum.

The non-infarcted group included 18 age and sex-matched patients that had died of a cause unrelated to cardiovascular disease (table 1). Only patients with a heart weight of less than 400 grams were included in the non-infarcted group (see below).

Study 2. Collagen content in the interventricular septum of hypertensive hypertrophic hearts

Since the heart weight of the infarct group was significantly increased as compared to the controls $(543 \pm 26 \mathrm{~g}$ vs $353 \pm 7 \mathrm{~g}$, mean $\pm \mathrm{sem}, \mathrm{n}=18$; 
$\mathrm{p}<0.0001$; table 1$)$ a second study, including 10 patients with cardiac hypertrophy and without a known history of myocardial infarction, was performed. Cardiac hypertrophy was defined as a heartweight above 400 grams (van-der-Laarse et al., 1989). The patients were divided into a hypertensive hypertrophy group $(n=5$, heartweight $542 \pm 48 \mathrm{~g})$ and a non-hypertensive hypertrophy group $(\mathrm{n}=5$, heartweight $457 \pm 7 \mathrm{~g}$, not significant as compared to the hypertensive hypertrophy group).

A patient was considered as hypertensive, having both a systolic bloodpressure higher than $140 \mathrm{mmHg}$ and a diastolic bloodpressure higher than $90 \mathrm{mmHg}$ during hospitalisation $(n=5$, lowest BP $140 / 90$, highest BP $170 / 100 \mathrm{mmHg}$ ). None of the hypertensive patients were using ACE-inhibitors. The antihypertensive medication, if used $(n=3)$, were beta-adrenoreceptor blockers.

The non-hypertensive patients had no history of hypertension, nor did they have increased bloodpressures during their hospitalisation. Since signs of valvular disease were also absent, this hypertrophy should be qualified as idiopathic.

\section{Sirius Red staining}

All tissue samples were taken at the level of the largest diameter of the papillary muscles. Full tissue sections of the interventricular septum were routinely processed and paraffin embedded. $6 \mu \mathrm{m}$ Sections were stained with the collagen specific dye Sirius Red, in the following manner ((Junqueira et al., 1979); fig 1): after washing in tab water (10') and in distilled water $\left(2 \times 2^{\prime}\right)$ the slides were treated with $0.2 \%$ phosphomolydic acid $\left(5^{\prime}\right)$. Then the $0.1 \%$ Sirius Red solution was applied (90'). Before dehydration, the slides were treated with $0.01 \mathrm{~N} \mathrm{HCl}\left(2^{\prime}\right)$. The Sirius Red positive tissue area (\% of total tissue area) was determined by computerized morphometry (CAS 200, Beckton and Dickinson). Measurements were performed in three regions of the interventricular septum i.e. the left ventricular subendocardial region, the mid-septal region and the right ventricular interventricular septal region, at a manification of $400 \mathrm{x}$. From each heart the mean of 20 high power fields measured in each region was taken. Perivascular regions were avoided. The measurements were performed in a blinded manner.

\section{Statistics}

Data are presented as mean \pm sem. Comparisons between the groups were performed by Student's t-test. $P<0.01$ was required for statistical significance. 


\section{RESULTS}

Study 1. Collagen content in the non-infarcted interventricular septum of the infarcted myocardium

Patients in this study were age and sex matched. The mean age of the patients in the infarcted group was $66.7 \pm 0.9$ years $(36-91$ years), and $66.1 \pm 0.7$ years ( $42-89$ years) in the controls. The mean heart weight in the infarct group was $543 \pm 26 \mathrm{~g}$ and in the control group $353 \pm 7 \mathrm{~g}$ $(\mathrm{n}=18, \mathrm{p}<0.0001$; table 1$)$.

There was no difference in collagen content between the left ventricular subendocardial, mid-septal and right ventricular subendocardial region, neither in the infarct group, nor in the controls (table 1).

The collagen content in the infarct group showed a marked increase as compared to the controls: the mid-septal collagen content in the infarcted group was $10.4 \pm 1.4 \%$ and the controls $4.1 \pm 0.7 \%(p<0.01$; figure 2$)$. When all data was stratified to time of death after infarction, no difference in collagen content could be detected (data not shown).

Table 1. study l: Patient characteristics and collagen amount (\%) in the noninfarcted human interventricular septum. mean \pm sem; ${ }^{*}=p<0.01$ as compared to controls.

SEX

INFARCT

$(\mathrm{n}=18)$
CONTROL

$(n=18)$

male

12

female

6

11

7

AGE (years)

$66.7(36-91)$

$66.1(42-89)$

HEART WEIGHT (grams)

$543 \pm 26$

$353 \pm 7$

COLLAGEN AMOUNT (\%)

left ventricular

subendocardial region

$7.5 \pm 1.4^{*}$

$2.7 \pm 0.5$

mid-septal

$10.4 \pm 1.4^{*}$

$4.1 \pm 0.7$

right ventricular

subendocardial region

$6.8 \pm 1.0 *$

$2.7 \pm 0.5$ 
Study 2. Collagen content in the interventricular septum of hypertensive hypertrophic hearts

In this study, the heart weights were matched with the heart weights in the infarct group of study 1 . There also was no significant difference in mean heartweight between the hypertensive hypertrophy group and in the non-hypertensive hypertrophy ( $542 \pm 48 \mathrm{~g}$ vs $457 \pm 14 \mathrm{~g}$; table 2 ).

There was no difference in collagen content between the left ventricular subendocardial, mid-septal and right ventricular subendocardial region, neither in the hypertensive hypertrophy group, nor in the nonhypertensive hypertrophy (table 2 ).

The collagen content, was significantly increased in the hypertensive hypertrophy as compared to the non-hypertensive hypertrophy, i.e. mid septal: $10.0 \pm 1 \%$ vs $4.2 \pm 0.3 \%, \mathrm{p}<0.01$ (figure 2 ).

The collagen content in the interventricular septum of the hypertensive hypertrophy group was also increased as compared to the controls from study 1. However, there was no significant difference in the collagen amounts of the hypertensive hypertrophied hearts as compared to the infarct group from study 1 . Also, the collagen content in the nonhypertensive hypertrophy group was not different from the collagen content in the control group from study 1.

Table 2. Study 2." Patient characteristics and collagen amount (\%) in the interventricular septum; mean \pm sem:

* $=\mathrm{p}<0.01$ as compared to the non-hypertensive

AGE (years)

HEART WEIGHT (grams)

COLLAGEN AMOUNT (\%)

left ventricular

subendocardial region

mid-septal

right ventricular

subendocardial region
HYPERTENSIVE HYPERTROPHY $(n=5)$

$71.8(60-85)$

$542 \pm 48$

NON-HYPERTENSIVE HYPERTROPHY $(\mathrm{n}=5)$

$52.4(32-67)$

$457 \pm 14$ (NS) 


\section{DISCUSSION}

This study contains several distinct observations. First of all it shows that it is possible to measure changes in collagen content in routinely processed human cardiac tissue. Changes in the collagen content have been studied with several different techniques. The measurement of the hydroxyproline content in freshly obtained material (Caspari et al., 1977; Weber et al., 1988; Bishop et al., 1990) is often used. Several authors have shown that the results obtained with the Sirius method are comparable with the results of the hydroxyproline assay (Dolber \& Spach, 1987). Important advantages of the Sirius Red over the hydroxyproline assay however, are the possibility to use routinely processed paraffin embedded tissue sections (Junqueira et al., 1979; Puchtler et al., 1988) as well as the possibility to localize the collagen within the tissue, and because of its stoichiometricity, to quantify the collagen content.
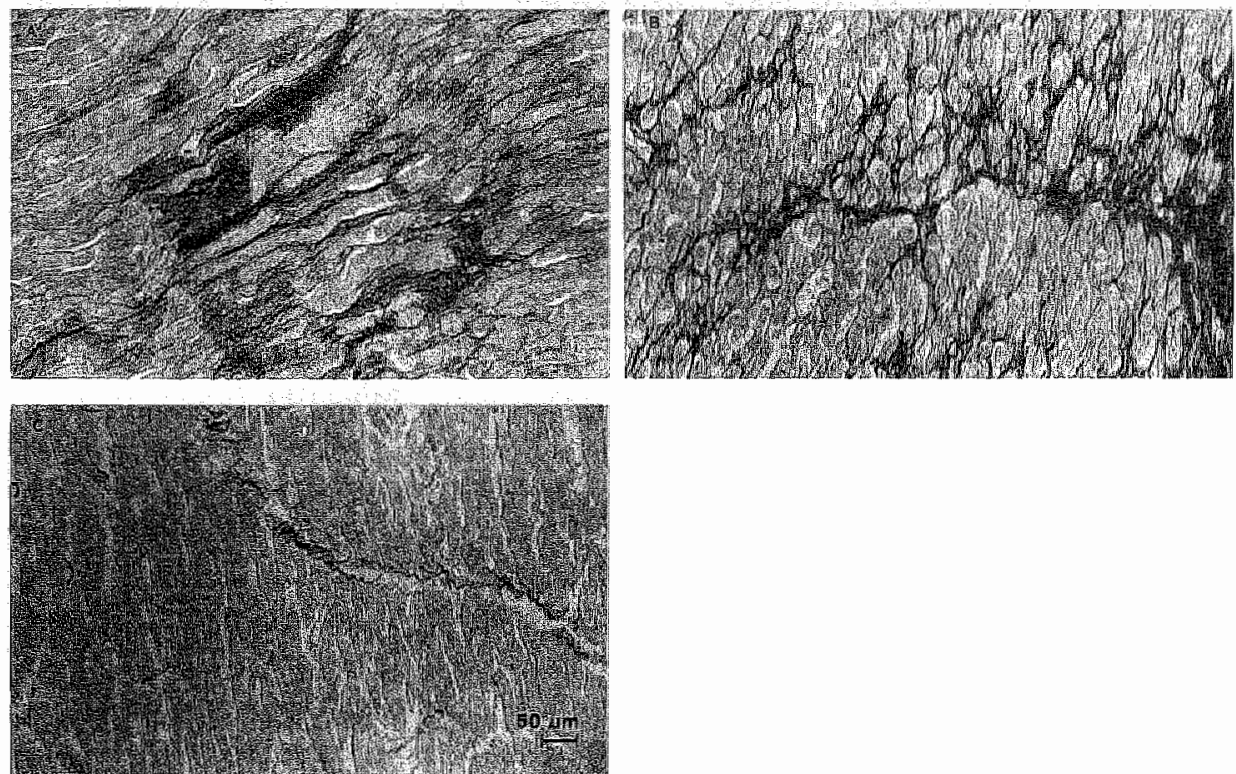

Figure 1: Interventricular septum stained with Sirius Red: A, infarction; B, Hypertensive hypertrophy; $\mathrm{C}$, non-hypertensive hypertrophy. 
Secondly, our study shows that the collagen content in both noninfarcted interventricular septum of hypertrophied, infarcted human hearts and in hypertrophied hypertensive hearts is significantly increased as compared to non-hypertrophic controls. Several authors have found an increase in collagen content in the pressure induced hypertrophied hearts of different animal species (Abrahams et al., 1987; Doering et al., 1988; Pick et al.. 1989; Chapman et al. "1990; Contard et al., 1991). In contrast, volume overload does not increase the myocardial collagen content of rats, as described by Michel et al (Michel et al., 1986). Also in human hearts increases in collagen content in pressure induced, but not in hypertrophy accompanying volume overload, have been described (Caspari et al., 1977; Schwarz et al., 1978; Pearlman et al., 1982; Schaper \& Schaper, 1983; Ginzton et al., 1989; van-derLaarse et al., 1989; Weber, 1989; Smits et al., 1991).

Since the collagen content of the interventricular septum of hypertrophied non-hypertensive hearts was not different from the nonhypertrophic controls, while the collagen content in the hypertensive hypertrophy group was increased, our data suggest that hypertrophy per se does not increase the collagen content and that a second factor, common in myocardial infarction and hypertension, is necessary to increase the collagen content of the heart. Several possible candidates have to be considered, including angiotensin II, catecholamines and myocyte injury. Although the data given in the current study do not allow to discriminate between possible mechanisms, it is tempting to suggest a role for angiotensin II and/or catecholamines in the control of interstitial collagen in hypertrophied human hearts. Indeed, increased plasma levels of angiotensin II and catecholamines are present after myocardial infarction and in several experimental models of hypertension. Recent data from our and other laboratories showed that the increase in collagen content in hypertrophied rat hearts after induction of a left ventricular wall infarction can be prevented by the administration of ACE-inhibitors. This finding suggests a role for angiotensin II in the control of interstitial collagen in the myocardium (Michel et al., 1988; van Krimpen et al., 1991b).

On the other hand high plasma levels of either catecholamines or angiotensin II are also known to cause myocyte injury with subsequent wound healing and increased amounts of interstitial collagen (Collins et al., 1975; Todd et al., 1980; Cho et al., 1987; Benjamin et al., 1989; Tan et al., 1991). Although overt myocyte injury was not apparent in our study, discrete myocyte injury can not be excluded. 


\section{MID INTERVENTRICULAR SEPTUM COLLAGEN CONTENT}

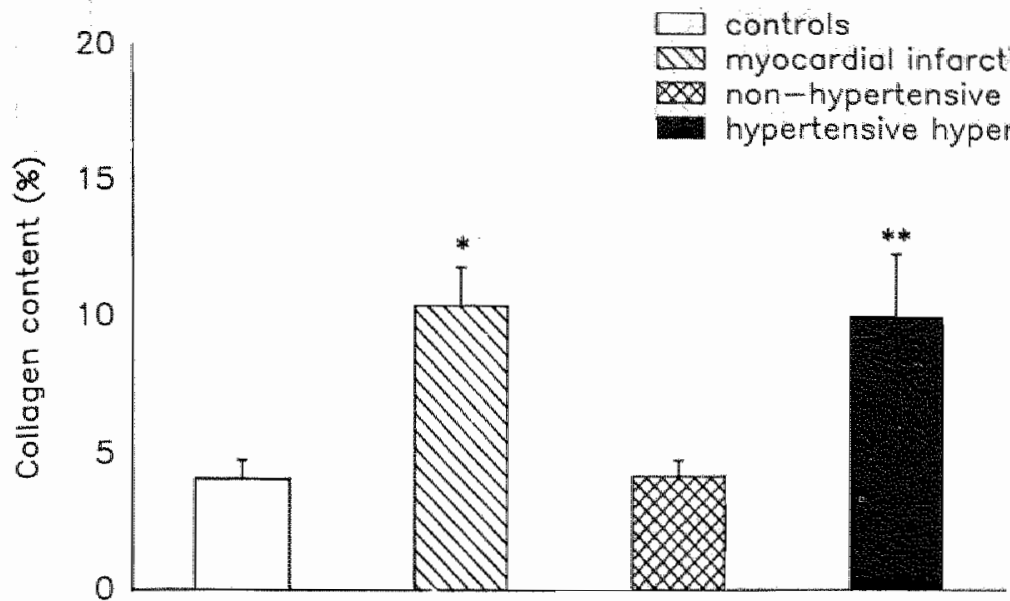

Figure 2. The collagen content in the mid interventricular septum in infarct, hypertrophy and controls. The collagen content is expressed as percentage of total tissue area. ${ }^{*}$, mean \pm sem, $p<0.01 ;{ }^{* *}$, mean \pm sem, $p<0.001$.

Other candidates have to be considered however. One of these, aldosterone, has recently been shown to increase the collagen content in the rat heart and it is likely that the plasma levels of aldosterone were elevated in the patients studied (Brilla et al., 1990).

Finally we did not find a significant difference between midventricular, left and right subendocardial interventricular regions of the septum, suggesting an equal distribution of collagen in the non-infarcted interventricular septum. When analyzing the data as a function of age of the patients, we did not find a significant difference in collagen content, neither in the subendocardial regions, nor in the mid-septal region. These findings are in contradiction with the study of Lenkiewicz et al (1972, (Lenkiewicz et al., 1972)), who examined the collagen amount in the interventricular septum as a function of age. These authors studied hearts from patients without cardiovascular disease and found increased collagen amounts in the subendocardial regions of the interventricular regions as compared to the midseptal region with increasing age. The reason for the different observations in the two studies is not clear. One 
reason might be the relative small numbers in the different age groups in this study.

In conclusion this study shows increased interstitial collagen contents in hypertrophied human hearts from patients with a previous history of myocardial infarction or hypertension, while no increases in interstitial collagen were found in "control" hypertrophied hearts. Although literature data suggest a role for angiotensin II, aldosterone, catecholamines and/or cardiomyocyte necrosis, the exact mechanisms involved in the control of interstitial myocardial collagen require further studies. 


\section{REFERENCES}

Abrahams C, Janicki JS, Weber KT. Myocardial hypertrophy in Macnca fascicularis. Structural remodeling of the collagen matrix. Lab lavest (1987) $56: 676-683$.

Benjamin IJ, Jalil TE, Tan LB, Cho K, Weber KT, Clark WA. Isoproternolinduced myocardial fibrosis in relation to myocyte necrosis. Circ Res (1989) $65: 657-670$.

Bishop JE, Greenbaum R, Gibson DG, Yacoub M, Laurent GI. Enhanced. deposition of predominantly type 1 collagen in myocardial disease. I Mol Coll Cardiol (1990) 22:1157-1165.

Brilla CG, Pick R, Lip B, Janicki JS, Weber KT. Remodeling in the rat right and left ventricles in experimental hypertension. Circulation (1990) Res, 67:13551364.

Caspari PG, Newcomb M, Gibson K, Harris P. Collagen in the normal and hypertrophied human ventricle. Cardiovasc Res (1977) 11:554-558.

Chapman D, Weber KT, Eghbali M. Regulation of fibrillar collagen types I and II and basement membrane type IV collagen gene expression in pressure overloaded rat myocardium. Circ Res (1990) 67:787-794.

Cho T, Tanimura A, Saito Y. Catecholamine-induced cardiopathy accompanied with pheochromocytoma. Acta Pathol Jpn (1987) 37:123-132.

Collins P, Billings CG, Barer GR, Daly JJ, Jolly A. Quantitation of isoprenalineinduced changes in the ventricular myocardium. Cardiovasc Res (1975) 9:797806.

Contard F, Koteliansky V, Marotte F, Dubus I, Rappaport L, Samuel JL. Specific alterations in the distribution of extracellular matrix components within rat myocardium during the development of pressure overload. Lab Invest (1991) $64: 65-75$

Doering CW, Jalil JE, Janicki JS, Pick R, Aghili S, Abrahams C, Weber KT. Collagen network remodeling and diastolic stiffness of the rat left ventricle with pressure overload hypertrophy. Cardiovasc Res (1988) 22:686-695.

Dolber PC, Spach MS. picrosirius red staining of cardiac muscle following phosphomolybdic acid treatment. Stain technol (1987) 62:23-26.

Eghbali M, Eghbali M, Robinson TF, Seifter S, Blumenfeld OO. Collagen accumulation in heart ventricles as a function of growth and aging. Cardiovase Res (1989) 23:723-729.

Ginzton LE, Conant $R$, Rodrigues DM, Laks MM. Functional significance of hypertrophy of the noninfarcted myocardium after myocardial infarction in humans. Circulation (1989) 80:816-822.

Junqueira LCU, Bignolas G, Brentani RR. Picrosirius staining plus polarization microscopy: A specific method for collagen detection in tissuc sections. Histochem J (1979) 11:447-455.

Lenkiewicz JE, Davies MJ, Rosen D. Collagen in human myocardium as a function of age. Cardiovasc Res (1972) 6:549-555.

Michel JB, Salzmann JL, Ossondo-Nlom M, Bruneval P, Barres D, Camilleri JP. Morphometric analysis of collagen network and plasma perfused capillary bed 
in the myocardium of rats during evolution of cardiac hypertrophy. Basic Res Cardiol (1986) 81:142-154.

Michel $J_{B}$, Lattion $A L$, Salzmann $J L$, de Lourdes Cerol $M$, Philippe $M$, Camelleri $J P$, Corvol P. Hormonal and cardiac effects of converting enzyme inhibition in rat myocardial infarction. Circ Res (1988) 62:641-650.

Pearlman ES, Weber KT, Jamicki IS, Pietra GG, Fishman AP. Muscle fiber orientation and connective tissue content in the hypertrophied human heart. Lab Invesi (1982) 46:158-164.

Pick R, Janicki JS, Weber KT: Myocardial fibrosis in nonhuman primate with pressure overload hypertrophy. Am J Pathol (1989) 135:771-781.

Puchtller H, Meloan SN, Waldrop FS. Are picro-dye reactions for collagens quantitative? Chemical and histochemical considerations. Histochem (1988) $88: 243-256$.

Schaper J, Schaper W. Ultrastructurall correlates of reduced cardiac function in human heart disease. Eur Heart J (1983) 4:35-42.

Schoemaker RG, Smits JF. Systolic time intervals as indicators for cardiac function in rat models for heart failure. Eur Heart J (1990) II Suppl I:114-123.

Schwarz F, Flameng W, Schaper J, Hehrlein F. Correlation between myocardial structure and diastolic properties of the heart in chronic aortic valve disease: Effects of corrective surgery. Am J Cardiol (1978) 42:895-903.

Smits JF, Cleutjens JP, van-Krimpen C, Schoemaker RG, Daemen MJ. Cardiac remodeling in hypertension and following myocardial infarction: effects of arteriolar vasodilators. Basic Res Cardiol (1991) 86 Suppl 1:133-139.

Tan LB, Jalil JE, Pick R, Janicki JS, Weber KT. Cardiac myocyte necrosis induced by Angiotensin II. Circ Res (1991) 69:1185 1195.

Todd GL, Cullan GE, Cullan GM. Isoproterenol-induced myocardial necrosis and membrane permeability alterations in the isolated perfused rabbit heart. Exp Mol Pathol (1980) 33:43-54.

van-der-Laarse A, Hollaar L, Vliegen HW, Egas JM, Dijkshoorn NJ, Cornelisse CJ, Bogers AJ, Quaegebeur JM. Myocardial (iso)enzyme activities, DNA concentration and nuclear polyploidy in hearts of patients operated upon for congenital heart disease, and in normall and hypertrophic adult human hearts at autopsy. Eur J Clin Invest (1989) 19:192-200.

vati-Krimpon C. Sehoonaket $\mathbf{R G}_{n}$ Clettjeris JP, Smits JF, Struyker-Boudier HA, Bosman FT, Datemen MJ. Angiotensin I converting enzyme inhibitors and cardiac remodeling. Basic Res Cardiol (1991a) 86 Suppl 1:149-155.

van Krimpen C, Smits JFM, Cleutjens IPM, Debets JJM, Schoenmaker RG, Struyker Boudier HAJ, Bosman FT, Daemen MJAP. DNA synthesis in the non-infarcted cardiac interstitium after left coronary artery ligation in the rat: effects of Captopril. J Mol Cell Cardiol (1991b) 23:1245-1253.

Weber KT. Cardiac interstitium in health and disease: the fibrillar collagen network. J Am Coll Cardiol (1989) 13:1637-1652.

Weber KT, Janicki IS, Shroff SG, Pick $R_{\text {n }}$ Chen RM, Bashey RI. Collagen remodeling of the pressure-overloaded, hypertrophied nonhuman primate myocardium. Circ Res (1988) 62:757-765.

Weber KT, Pick R, Jalil JE, Janicki JS, Carroll EP. Patterns of myocardiall 
Chapter 2

fibrosis. J Mol Cell Cardiol (1989) 21 Suppl 5:121-131. 

ALPHA SMOOTH MUSCLE ACTIN POSITTVE CELLS IN HEALING HUMAN MYOCARDIAL SCARS

Willems IEMG, Havenith MG, De Mey JGR, Daemen MJAP. Am J Pathol 1994 Oct;145(4):868-875 


\section{SUMMARY}

Interstitial cells in the scars of human myocardial infarctions of different postinfarction time (6 hours to 17 years old) were characterized by antibodies to a-smooth muscle actin (ASMA), vimentin and desmin. Basal lamina deposition was studied with antibodies to the basal lamina protein type IV collagen.

Non-vascular spindle shaped cells expressing ASMA were present within 4 to 6 days after infarction. These cells co-expressed vimentin, but no desmin, and showed discontinuous basal lamina deposition. In electron microscopy these cells showed features, characteristic of myofibroblasts. The spindle-shaped cells persisted for a long period of time, and could even be identified 17 years postinfarction. In transmural infarctions they were orientated parallel to the endo- and epicardium. In nontransmural, patchy, infarctions they showed an orientation adjacent to the cardiomyocytes and appeared to be less dense than in the transmural infarctions.

In conclusion myofibroblast, expressing $\alpha$-smooth muscle actin persist within human myocardial scars and show a preferential alignment, which may be the result of the continuous mechanical stress caused by the ongoing contraction and relaxation of the surrounding viable myocardium.

\section{INTRODUCTION}

After necrotizing injuries, like an infarction, the myocardial tissue responds by inflammation and repair. During this process necrotic tissue is replaced by granulation tissue that matures into scar tissue. In granulation tissue characteristic interstitial spindle shaped cells have been observed. These cells were called myofibroblasts (MF's) and exhibit contractile properties (Baur et al., 1984). MF's share characteristics of both fibroblasts and smooth muscle cells and their original definition is based on ultrastructural criteria (Gabbiani et al., 1971). Characteristic ultrastructural features of MF's are both the presence of stress fibres with subplasmalemmal attachment plaques and abundant rough endoplasmic reticulum, next to a discontinuous deposition of basal lamina-like material (Lipper et al., 1980). Immunohistochemical analysis of MF's revealed a heterogeneous cytoskeletal composition under different pathological conditions. Healed 
dermal scars expressed only vimentin, while coexpression of $\alpha$-smooth muscle actin (ASMA) and desmin was observed in hypertrophic dermal scars and fibromatosis (Skalli et al., 1989). During experimental dermal wound healing in rats the appearance of MF"s is transient. The first ASMA and vimentin positive cells appear at day 6 but can no longer be detected after week 4 . Furthermore, they are oriented parallel to the wound surface and perpendicular to the vessels (Darby et al., 1990).

In experimentally induced myocardial infarctions in rats the first ASMA expressing spindle shaped cells were identified between day 2 and 4 (Vracko \& Thorning, 1991). In contrast to dermal scars, they persisted up to 10 weeks in the rat, and showed a parallel orientation to surviving cardiomyocytes present at the border of the infarction. In this and other models of wound healing also basal lamina deposition was detected, especially at the interface of the scar and the surrounding stromal tissue (Seemayer et al., 1980; Schurch et al., 1984).

Since no information is available on the presence of ASMA expressing spindle shaped cells in human myocardial scars, we investigated the appearance of these cells in human myocardial infarctions with different postinfarction survival times, varying from less than 2 days to several years.

\section{MATERIALS AND METHODS}

\section{Source of tissue}

Tissue blocks of human myocardial infarctions, obtained during autopsy, were retrieved from the archives of the Department of Pathology of the University Hospital of Maastricht. For inclusion in this study the duration from the first signs of myocardial infarction to the demise of the patient had to be known. Furthermore, infarct duration was estimated histologically (Bouchardy \& Majno, 1974). A patient was included in the study, when the clinical and histological postinfarction survival time were in agreement. Based on these criteria a total number of 35 infarct cases and an additional non-infarcted control group with no cardiac history of any kind (group $0 ; n=5$ ), were studied. The infarct group was subdivided in five groups. Group 1 included 5 cases with a postinfarction time of less than 2 days, group 2 included 6 cases with a postinfarction time of 2 to 7 days, group 3 included 10 cases with a postinfarction time of 1 to 2 weeks, group 4 six cases with a postinfarction time of 2 to 4 weeks and group 5 eight cases with a 
postinfarction time exceeding 4 weeks.

\section{Electron microscopy}

Small tissue cubes of infarcted areas (postinfarction time over 4 weeks) were obtained during autopsy (postmortem time less than 4 hours) and fixed in $2,5 \%$ glutaraldehyde for 4 hours, postfixed in $1 \%$ osmium tetroxide in $0.1 \mathrm{M}$ phosphate buffer ( $\mathrm{pH} 7.2$ ) for 1 hour, dehydrated and embedded in epon 812. Semithin sections were cut and stained with methylene blue, to select representative areas. These were collected on coppergrid, contrasted with saturated uranylacetate in 50 percent ethanol and $10 \%$ leadcitrate, and examined with a Philips CM 12 transmission electrón microscope.

\section{Immunohistochemistry}

Tissue blocks from the infarcted myocardium were fixed in $4 \%$ neutral buffered formaldehyde and embedded in paraffin according to routine procedures. Adjacent sections of each block were stained with the respective antibodies. After deparaffinization, $4 \mu \mathrm{m}$ thick sections were washed $3 \times 5 \mathrm{~min}$ in Tris buffered saline (TBS). Thereafter, endogenous peroxidase activity was blocked by $0.1 \% \mathrm{H}_{2} \mathrm{O}_{2}$ in methanol for $20 \mathrm{~min}$ at room temperature (RT) and the sections were incubated during 45 minutes with antibodies to alpha smooth muscle actin (ASMA monoclonal antibody, Sigma, dilution 1:4000), desmin (monoclonal antibody, Organon, dilution 1:100), vimentin (monoclonal antibody, Organon, dilution 1:100), or type IV collagen (polyclonal antibody, dilution 1:500). The specificity of these antibodies has been described elsewhere (Skalli et al., 1986; Havenith et al., 1987; van Muyen et al., 1987). To expose the antigenic sites for antibodies directed against vimentin and type IV collagen, preincubation with $0.1 \%$ pepsin (Boehringer) in $0.1 \mathrm{~N} \mathrm{HCl}, \mathrm{pH}$ 2.0 for $30 \mathrm{~min}$ at RT was required. After incubation with the antibody the sections were washed $3 \times 5$ min with TBS and incubated with horseradish peroxidase conjugated swine anti rabbit (DAKO, dilution 1:150) for the anti-type IV collagen antibody or rabbit anti mouse antibodies (DAKO, dilution 1:200) for anti-ASMA, desmin and vimentin antibodies respectively, during $45 \mathrm{~min}$ at $\mathrm{RT}$. After final washing with TBS, a diaminobenzidine- $\mathrm{H}_{2} \mathrm{O}_{2}$ substrate was used to visualize the immunoreactiwity. To enhance the precipitation of the chromogen, $0.1 \mathrm{M}$ imidazole was added to the substrate. When the presence of pigmentloaden macrophages obscured the interpretation of the immunohistological findings aminoethylcarbazole was used as the substrate. Before mounting, the 
sections were weakly counterstained with Mayer's haematoxylin.

\section{RESULTS}

In the control and the non-infarcted myocardial tissue of all other groups, ASMA immunoreactivity could only be detected in the media of arteries and veins and in pericytes surrounding arterioles and venules. ASMA expressing spindle shaped cells not belonging to the vascular smooth muscle cell compartment were examined with regard to their alignment, immunophenotype and presence in time.

\section{Group 0: Controls}

Interstitial cells located in the subendocardial space showed a parallel orientation to the endothelial lining and expressed ASMA. The cells expressing ASMA, showed a discontinuous pericellular immunoreactivity with type IV collagen and a weak intracytoplasmatic immunoreactivity with vimentin. However, only very few of these subendocardial cells showed immunoreactivity for desmin.

Interstitial cells in the myocardium as well as cardiomyocytes and endothelial cells lacked any immunoreactivity for ASMA. Intracytoplasmatic immunoreactivity for vimentin could be observed next to pericytes, in myocardial interstitial cells, endothelial cells, fat cells, inflammatory cells and vascular smooth muscle cells. The anti-desmin antibody stained vascular smooth muscle cells as well as cardiomyocytes. Immunoreactivity for type IV collagen was absent around myocardial interstitial cells but the antibody stained all basal laminas around individual cardiomyocytes, vascular smooth muscle cells, pericytes, Schwann cells, fat cells, and the basal lamina underlying endothelial cells.

\section{Group 1." 6-48h infarction}

In infarctions with a postinfarction time of less than 2 days, cardiomyocytes in the infarcted area clearly showed depletion of desmin. The expression of ASMA in infarcted areas was restricted to vascular structures (Fig. 1a). Vimentin was expressed weakly in vessel walls but stained densely in the inflammatory infiltrate. The scaffold of the basal lamina around cardiomyocytes was almost completely intact in the infarcted tissue, especially in the central areas that showed no infiltration by inflammatory cells. 


\section{Group 2:2-7 days infarction}

The first spindle shaped cells expressing intracytoplasmatic ASMA appeared between day 4 and 6 in the granulation tissue at the interface of vital myocardium and infarct area (Fig. 1b). These spindle shaped cells co-expressed vimentin (Fig. 2a), which was also expressed by inflammatory cells, that were present in high numbers at the margin of the infarction. In the infarcted area only smooth muscle cells of remaining vessel walls expressed desmin, while no desmin expression was found in cardiomyocytes or ASMA positive non vascular spindle shaped cells. Type IV collagen was expressed in remnants of cardiomyocytic basal laminas and in a discontinuous pattern, around the spindle shaped cells in the infarcted area.

\section{Group 3: 1-2 weeks infarchion}

In 1 to 2 weeks old non-transmural infarctions, the spindle shaped cells were oriented parallel to adjacent surviving myocardial cells (Fig. 1c). In transmural infarctions they were oriented parallel to the endo- and epicardium. Again these cells did not show immunoreactivity with desmin (Fig. 2b). ASMA and vimentin were present in the cytoplasm and type IV collagen was present in a discontinuous pattern around the spindle shaped cells. Also remnants of cardiomyocytic basal laminas, still expressed collagen type IV (Fig. 2c).

\section{Group 4: 2-4 weeks infarction}

In the period from week 2 to 4 the staining pattern was identical to the pattern described in group 3 and the parallel orientation of the spindle shaped cells to surviving cardiomyocytes or endo- and epicardium was even more pronounced. Apart from vessel walls, desmin could be detected in a few spindle shaped cells in the scar tissue (Fig. 2d).

\section{Group 5: more than 4 weeks infarction}

In more than 4 weeks old infarctions the same pattern persisted, even in scar tissue with a postinfarction time of 17 years (Fig. 1d). ASMA positive spindlle shaped cells in non-transmural infarctions showed an orientation parallel to the adjacent cardiomyocytes, and appeared to be less dense than in transmural infarctions. The spindle shaped cells in transmural infarctions showed a striking parallel orientation to the endoand pericardium. Ultrastructurally the ASMA expressing spindle shaped cells were multipolar, with abundant dilated rough endoplasmic reticulum, a golgi vesicular transport system, and microfilaments 
extending into subplasmalemmal attachment plaques, characteristic for myofibroblasts (Fig 3).

\section{DISCUSSION}

Many authors have shown the presence of myofibroblasts in heart valves, lung interstitium (Kapanci et al., 1974; Filip et al., 1986; Adler et al., 1989) and in pathologic conditions as wound healing, fibromatosis, tumour surrounding stroma, and intima formation in aortic grafts (Sottiurai \& Batson, 1983; Vande-Berg et al., 1984; Battersby \& Anderson, 1985; Tomasek et al., 1986; Matsuoka et al., 1988; Stout et al., 1988; Adler et al., 1989; Pourreau-Schneider et al., 1990). Myofibroblasts were also found in the infarcted myocardium of the rat and in the pressure overloaded right ventricle in the rabbit (Leslie et al., 1991; Vracko \& Thorning, 1991), but the immunophenotype of myofibroblasts is heterogenous. In the present study MF's were identified in human myocardial scars (El-Labban \& Lee, 1983; Eddy et al., 1988; Darby et al., 1990; Vracko \& Thorning, 1991; Foo et al., 1992) and were found to co-express vimentin and $\alpha$-smooth muscle actin. These cells showed the ultrastructural features of myofibroblasts (Ghadially, 1988). Only very few MF's showed desmin expression, and if so, only from 2-4 weeks postinfarction. The vast majority of myofibroblasts in human myocardial scars would therefore be VA-cells, according to a proposed immunophenotypic division of MF's (Darby et al., 1990). To further illustrate their heterogeneity, we summarized characteristics of MF's in myocardial scars in humans and rats, as well as in dermal wounds in rats (Table 1). MF's in all these studies expressed both vimentin and ASMA. In both rat and human myocardial studies desmin expression was found in the spindle shaped cells. We found sustained expression of the basal lamina protein collagen IV in early human myocardial scars. From ultrastructural studies in the rat it was already known that myocyte- as well as vascular- and Schwann cell basal laminae remain intact, after induction of myocardial infarction (Vracko et al., 1988). In older human myocardial infarctions collagen IV was present in a discontinuous pattern in the basal lamina of MF's, which coincides with the findings in the rat myocardial infarction study. The presence of collagen type IV in dermal wounds is not well described in the literature.

The appearance in time of MF's in human myocardial scars is 
comparable to the finding in the rat myocardium, where MF's appeared between day 2 and 4 after coronary artery ligation, and persisted for at least 4 weeks (table 1). Normal rat (Vracko et al., 1989) and normal and hypertrophied human myocardium (this study) lack MF's. The persistence of ASMA positive MF's in myocardial scars (in our study up to 17 years) is in contrast with the findings in dermal wound healing were expression of ASMA is only transient (Darby et al, 1990): the first ASMA positive MF's appeared 6 days after experimental dermal wounding in rats, reached a peak at day 15 , but could no longer be identified one month after induction of the wound.

Table 1 Characteristics of myofibroblasts in human and rat myocardial scars and in dermal scars. Data obtained from this study (human myocardial scars); Vracko et al (ref Vracko \& Thorning, 199I; rat myocardial scars); Darby et al (ref Darby et al., 1990; dermal wounds).

\section{Human MI \\ Huma MI}

Rat MI

Vimentin

Actin

Desmin

Coll IV

Time course

Orientation

+
$-1+$
+

continuous

parallel to surviving myocardium
Dermal wounds

$$
\begin{aligned}
& + \\
& + \\
& + \\
& ?
\end{aligned}
$$

transient

parallel to surface

Another striking observation made in this study is the orientation of MF's in the scars. They were always oriented parallel to surviving adjacent cardiomyocytes in non-transmural, patchy infarctions, but parallel to the endo- and epicardium in transmural infarction. In addition it was noted that $\alpha$-smooth muscle actin immunoreactivity was more intense in transmural than in patchy infarctions. MF's in small myocardial scars in the rat also showed a parallel orientation to surviving cardiomyocytes (Vracko \& Thorning, 1991) (table 1). In experimental dermal wound healing in rats MF's were oriented parallel to the epidermal surface and perpendicular to vascular structures 8 days after inducing the wound. It is known from experimental dermal 

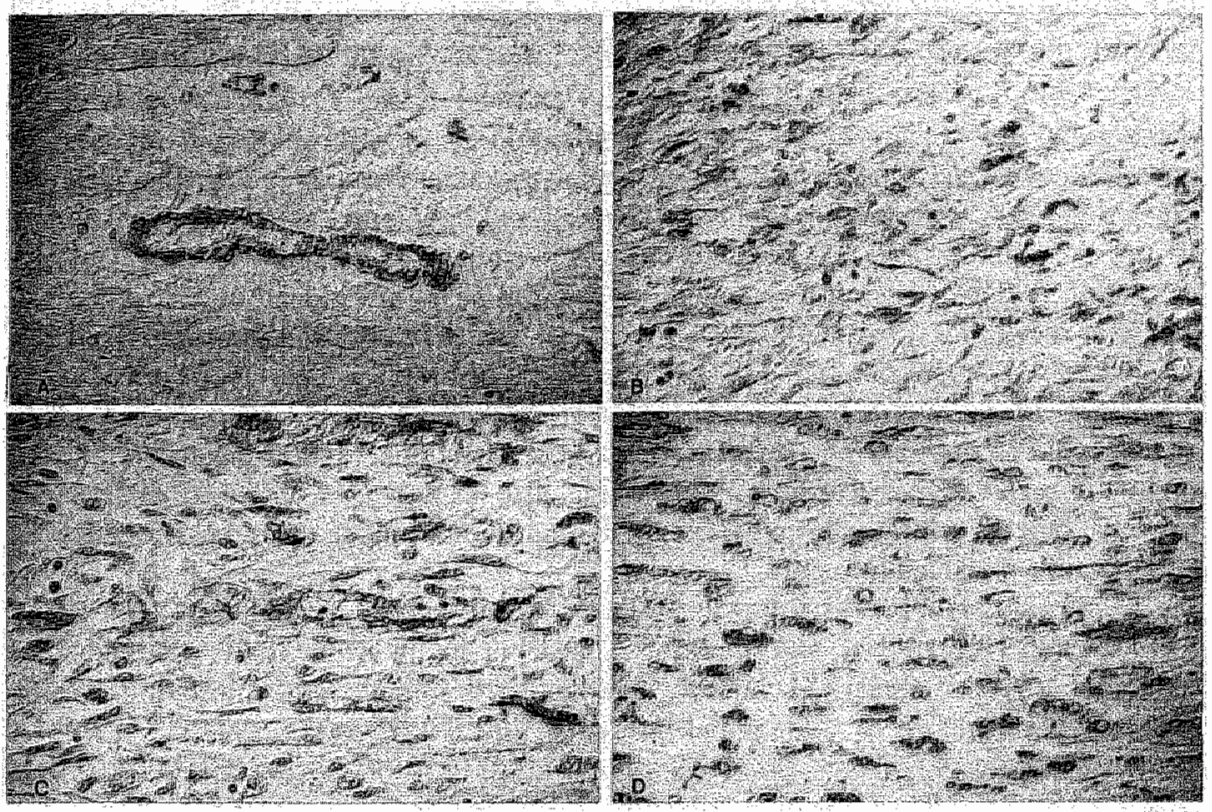

\section{Figure 1}
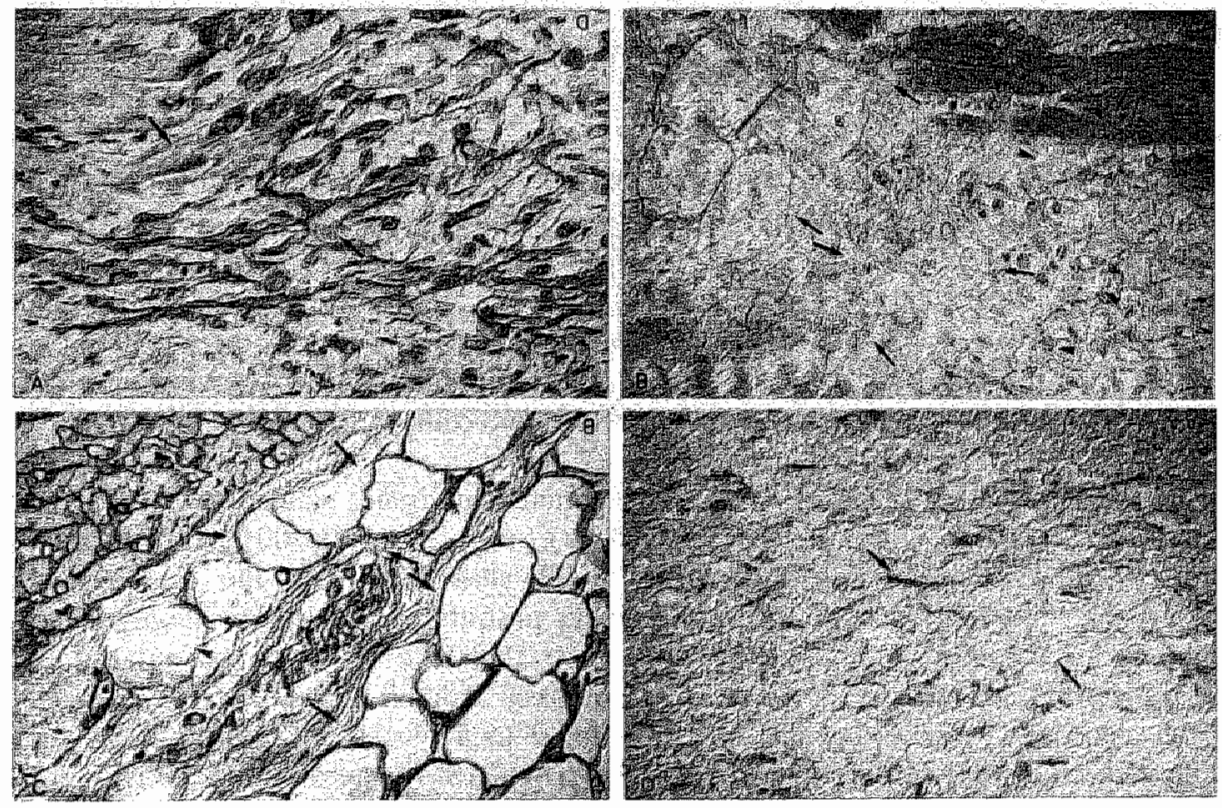

\section{Figure 2}


wounding in mice, that MF's were aligned circumferentially to the wound margin to close the wound in a purse string effect (Baur et al., 1984). This alignment disappeared within 4-5 days. The reason for the persistence and apparently determined orientation of myofibroblasts in myocardial scars is not clear. The expression of the cytoskeletal protein actin provides the myocardial scar with the possibility to contract and counteract the mechanical forces of the surrounding myocardium. Preliminary studies using the Mulvany-Halpern myograph indicate that rat and human myocardial scars are indeed able to contract, but with an unique pharmacological profile (J. De Mey, personal communication). A possible explanation of the persistence of myofibroblasts and their preferential alignment in myocardial scars, in contrast to dermal scars, is the continuous mechanical stress caused by the ongoing contraction and relaxation of the surrounding viable myocardium. This might also explain the observed differences between patchy infarctions and large, transmural infarctions, as a consequence of the different mechanical forces.

The in this study observed subendocardial arranged spindle shaped cells expressing ASMA could actually be myofibroblats appearing in the context of woundhealing following small endocardial injury, analogous to endothelial injury in arteries (Daemen et al., 1991) or myocardial infarction (this study).

Legends to the figures, previous page ( $p 75$ ).

Figure 1 Photomicrograph of human myocardial scar tissue of different postinfarction time stained with anti-ASMA (magnification $\times 200$ ). A: normal myocardium: ASMA expression is restricted to the vascular structures; $\mathbf{B}: 2$ to 7 days postinfarction: ASMA expression in the granulation tissue at the interface of vital myocardium and infarcted area; $C: \mathbb{1}$ to 2 weeks postinfarction: ASMA expression in the granulation tissue. Note the parallel orientation to the surrounding viable cardiomyocytes; D: $>4$ weeks postinfarction: ASMA expression is abindant. Note the alignment of the ASMA-positive cells.

Figure 2 Photomicrograph of human myocardial scar tissue, stained with different antibodies (vimentin, desmin, and collagen IV) (magnification $\times 200$ ). A: Vimentin, 2 to 7 days postinfarction. Interstitial spindle-shaped cells in the scar tissue, expressing vimentin; B: Desmin, 1 to 2 weeks postinfarction. Vital cardiomyocytes remain to express desmin; C: Collagen type IV, 1 to 2 weeks postinfarction. Subepicardial scar tissue shows remnants of basal laminas of cardiomyocytes. Fat cells also contain basal laminas; D: Desmin, 2 to 4 weeks postinfarction. In the infarcted area some spindle-shaped cells expressing ASMA are desmin positive. 
In the last years several molecules have been identified that show the ability to induce ASMA expression in frbroblasts (Pierce et al, 1991; Desmouliere et al., 1992), endothelial cells (Amberger et al., 1991) and fat-storing cells in the liver (Bachem et al., 1993), including heparin (Desmouliere et al., 1992), endothelin (Thiemermann \& Corder, 1992), TNF $-\alpha$, PDGF, and GM-CSF (Vyalov et al., 1993). Recently, Desmouliere et al proposed $\mathrm{TGF}-\mathrm{Bl}$ as the key molecule for the induction of ASMA expression in subcutaneous granulation tissue in rats, and in cultured human and rat fibroblasts (Desmouliere et al., 1993). The effect of other factors like endothelin is possible indirect and also involves TGF-131. (Thiemermann \& Corder, 1992; MacLellan et al, 1993). TGF-BI is present in the developing and adult heart (Heine et al., 1991; Engelmann et al., 1992), its immunoreactivity disappears in the central necrotic part of an experimentally induced myocardial infarction, but a strong immunoreactivity and increased mRNA amounts were found at the margins of the infarcted area (Thompson et al., 1988). Thus, TGF- $\beta 1$ may colocalize with MF's in the infarct. TGF- $\beta 1$ also stimulates the production of interstitial collagen which is increased after myocardial infarctions in rats and humans (van-Krimpen et al., 1991; Volders et al., 1993). Although no data are available on the expression of TGF- $\beta 1$ in human myocardial scars, the available data do certainly suggest a role for the molecule in inducing MF's in human myocardial scars.

The findings in this study illustrate that the healing processes in a myocardial scar differs from that in a dermal wound. ASMA positive myofibroblasts persist in myocardial scars and have a preferred orientation, while the same cells are only transiently present in dermal wounds, and without a preferred orientation. The difference is probably due to the different environments in which the healing processes take place. 


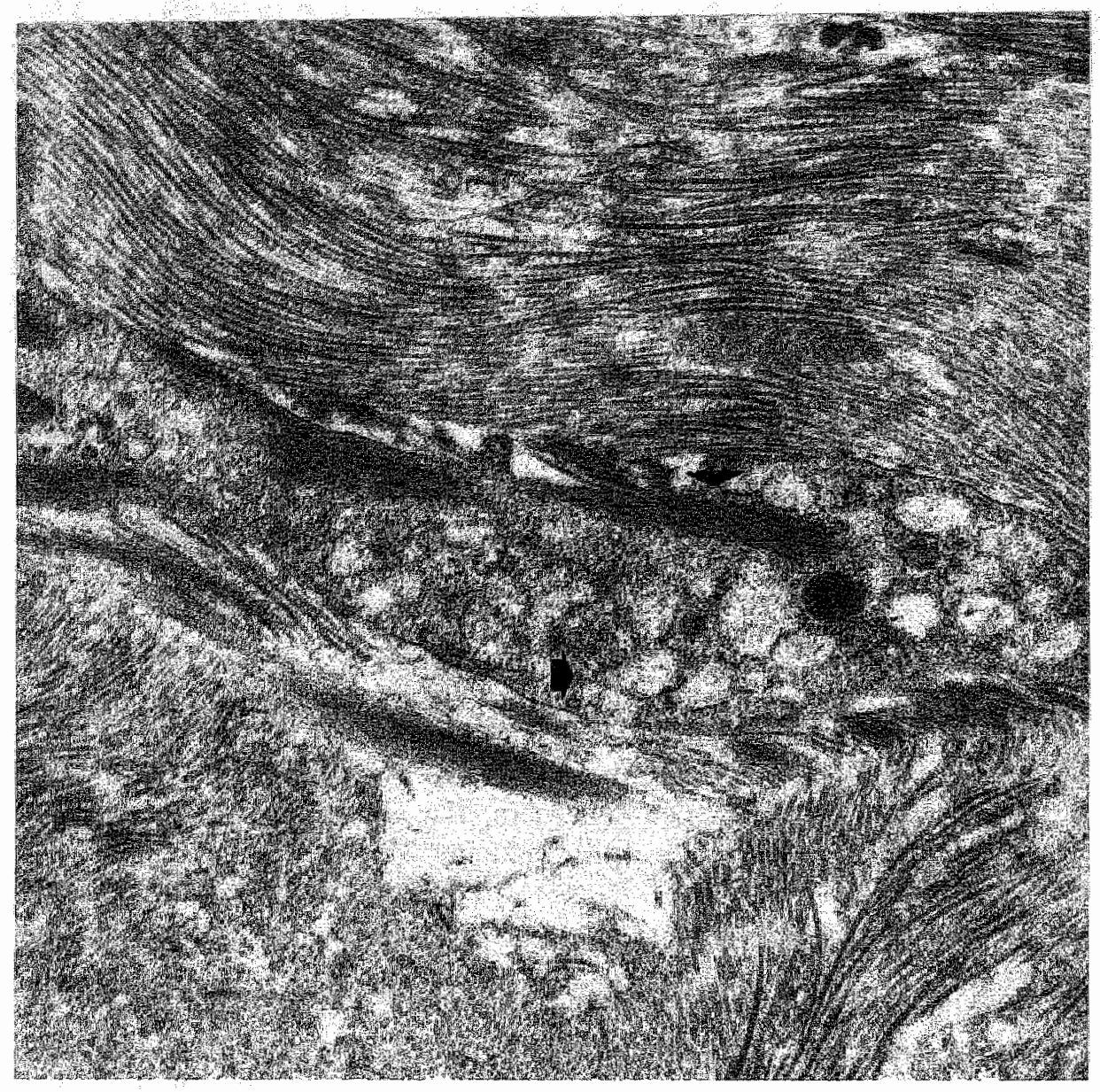

Figure 3 Electron photomicrograph of human myocardial scar tissue (magnification $x \quad 20,400$ ) detailing the cytoplasm of an interstitial cell with ultrastructural charateristics of a myofibroblast; abundant rough endoplasmic reticulum (arrow) and intracytoplasmic filaments with dense bodies (arrowhead). 


\section{REFERENCES}

Adler $\mathrm{KB}$, Low RB, Leslie $\mathrm{KO}$, Mitchell $\mathrm{J}$, Evans $\mathrm{N}$. Contractile cells in normal and fibrotic lung. Lab Invest (1989) 60:473-485.

Amberger A, Bauer H, Tontsch U, Gabbiani G, Kocher O, Bauer HC. Reversible expression of sm alpha actin protein and sm alpha actin mRNA in cloned cerebral endothelial cells. FEBS (1991) 287:223-225.

Bachem MG, Sell KM, Melchior R, Kropf J, Eller T, Gressner AM. Tumor necrosis factor alpha (TNF-allhpa) and transforming growtli factor beta-1 (TGF-beta-1) stimulate fibronectin synthesis and the transdifferentiation of fatstoring cells in the rat liver into myofibroblasts. Virchows Arch B Cell Pathol (1993) 63:123-130.

Battersby S, Anderson TJ. Myofibroblast activity of radial scars. J Pathol (1985) $147: 33-40$.

Baur PS Jr, Parks DH, Hudson JD. Epithelial mediated wound contraction in experimental wounds--the purse-string effect. J Trauma (1984) 24:713-720.

Bouchardy B, Majno G. Histopathology of early myocardial infarcts. A new approach. Am J Pathol (1974) 74:301-330.

Daemen MJAP, Lombardi DM, Bosman FT, Schwartz SM. Angiotensin II induces smooth muscle cell proliferation in the normal and injured rat arterial wall. Circ Res (1991) 68:450-456.

Darby I, Skalli O, Gabbiani G. Alpha-smooth muscle actin is transiently expressed by myofibroblasts during experimental wound healing. Lab Invest (1990) 63:21-29.

Desmouliere A, Rubbia-Brandt L, Grau G, Gabbiani G. Heparin induces alphasmooth muscle actin expression in cultured fibroblasts and in granulation tissue myofibroblasts. Lab Invest (1992) 67:716-726.

Desmouliere A, Geinoz A, Gabbiani F, Gabbiani G. Transforming growth factorbeta 1 induces alpha-smooth muscle actin expression in granulation tissue myofibroblasts and in quiescent and growing cultered fibroblasts. $\mathrm{J}$ Cell Biol (1993) 122:103-111.

Eddy RJ, Petro JA, Tomasek JJ. Evidence for the nonmuscle nature of the "myofibroblast" of granulation tissue and hypertropic scar. An immunofluorescence study. Am J Pathol (1988) 130:252-260.

El-Labban NG, Lee KW. Myofibroblasts in central giant cell granuloma of the jaws: an ultrastructural study. Histopathol (1983) 7:907.918.

Engelmann GL, Boehm KD, Birchenall-Roberts MC, Ruscetti FW. Transforming growth factor-beta 1 in heart development. Mech Dev (1992) 38:85-97.

Filip DA, Radu A, Simionescu M. Interstitial cells of the heart valves possess characteristics similar to smooth muscle cells. Circ Res (1986) 59:310-320.

Foo ITH, Naylor IL. Timmons MJ, Trejdosiewicz LK. Intracellular actin as a marker for myofibroblasts in vitro. Lab Invest (1992) 67:727-733.

Gabbiani G, Ryan GB, Majno G. Presence of modified fibroblasts in granulation tissue and their possible role in wound contraction. Experientia (1971) 27:549-550.

Ghadially FN Ultrastructural Pathology of the cell and matrix. (1988) (3rd ed., 
Vol. 2). London, Butterworths.

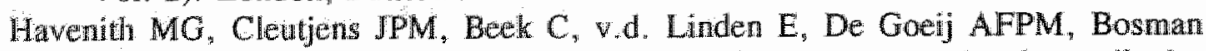

FT. Hurnan specific anti-type IV collagen monoclonal antibody, characterisation and immunohistochemical application. Histochem (1987) 87: 123-128.

Heine Ul, Burmester JK, Flanders KC. Localization of transforming growth factorbeta 1 in mitochondria of murine heart and liver. Cell Regul (1991) 2:467. 477.

Kapanci $Y$, Assimacopoulos A, Irle C, Zwahlen A, Gabbiani G. Contractile interstitial cells in pulmonary alveolar septa: ultrastructural, immunofluorescence and in vitro studies: a possible regulation of ventilation/perfusion ratio. J Cell Biol (1974) 60:375-392.

Leslie KO, Taatjes DJ, Schwarz J, von Turkovich M, Low RB. Cardiac myofibroblasts express alpha smooth muscle actin during right ventricular pressure overload in the rabbit. Am J Pathol (1991) 139:207-216.

Lipper S, Kahn LBB, Reddick RL. The myofibroblast. Pathol Ann (1980):409-441. MacLellan WR, Brand $T$, Schneider MD. Transforming growth factor-beta in cardiac ontogeny and adaptation. Circ Res (1993) 73:783-791.

Matsuoka LY, Uitto $J$, Wortsman $J$, Abergel RP, Dietrich J. Ultrastructural characteristics of keloid fibroblasts. Am J Dermatopathol (1988) 10:505-508.

van Muyen, Ruiter DJ, Warnaar SO. Coexpression of intermediate fillament polypeptides in fetal and adult tissue. Lab Invest (1987) 57:359-369.

Pierce GF, Varide Berg J, Rudolph R, Tarpley J, Mustoe TA. Platelet-derived Growth Factor-BB and Transforming Growth Factor-beta 1 selectively modulate glycosaminoglycans, collagen and myofibroblasts in excisional wounds. Am J Pathol (1991) 138:629-646.

Pourreau-Schneider N, Ahmed A, Soudry M, Jacquemier J, Kopp F, Franquin JC, Martin PM. Helium-neon laser treatment transforms fibroblasts into myofibroblasts. Am J Pathol (1990) 137:171-178.

Schurch W, Seemayer TA, Lagace R, Gabbiani G. The intermediate filament cytoskeleton of myofibroblasts: an immunofluorescence and ultrastructural study. Virchows Arch A (1984) 403:323-336.

Seemayer TA, Lagace R, Schurch W, Thelmo WL. The myofibroblast: Biologic, pathologic and theoretical considerations. Pathol Ann (1980):443-470.

Skalli O, Ropraz P, Trzeciak A, Benzonana G, Gillessen D, Gabbiani G. A monoclonal antibody against alpha-smooth muscle actin: a new probe for smooth muscle diflerentiation. J Cell Biol (1986) 103:2787-2796.

Skalli O, Schurch W, Seemayer T, Lagace R, Montandon D, Pittet B, Gabbiani G. Myofibroblasts from diverse pathologic settings in their content of actin isoforms and intermediate filament proteins. Lab Invest (1989) 60:275-285.

Sottiurai VS, Batson RC. Role of myofibroblasts in pseudointima formation. Surgery (1983) 94:792-801.

Stout LC, Boor PJ, Whorton EB Jr. Myofibroblastic proliferation on mitral valve chordae tendineae: a distinctive lesion associated with alcoholic liver disease. Hum Pathol (1988) 19:720-725.

Thiemermann C. Corder R. Is Endothelin-1 the regulator of myofibroblast 
contraction during woundhealing? Lab Invest (1992) 67:677-679.

Thompson NL, Bazoberry F, Speir EH. Transforming growth factor-beta 1 in acute myocardial infarction in rats. Growth Fact (1988) 1:91-99.

Tomasek JJ, Schultz RJ, Episalla CW, Newman SA. The cytoskeleton and extracellular matrix of the Dupuytren's disease "myofibroblast": an immunofluorescence study ofa monmuscle cell type. J Hand Surg Am (1986) $11: 365-371$.

Vande-Berg IS, Rudolph R, Woodward M. Growth dynamics of cultured myofibroblasts from human breast cancer and nonmalignant contracting tissues. Plast Reconstr Surg (1984) 73:605-618.

van-Krimpen C. Schoemaker RG, Cleutjens JP, Smits JF, Struyker-Boudier HA, Bosman FT, Daemen MJ. Angiotensin I conwerting enzyme inhibitors and cardiac remodeling. Basic Res Cardiol (1991) 86 Suppl 1:149-155.

Volders PGA, Willems IEMG, Cleutjens JPM, Arends JW, Havenith MG, Daemen MJAP. Interstitial collagen is increased in the non-infarcted human myocardium after myocardial infarction. J Mol Cell Cardiol (1993) 25: 1317 1323.

Vracko $\mathrm{R}$, Thorning D. Contractile cells in rat myocardial scar tissue. Lab Invest (1991) 65:214-227.

Vracko $R$, Cunningham $D$, Frederickson $R G$, Thorning $D$. Basal lamina of rat myocardium. Its fate after death of the cardiac myocytes. Lab Invest (1988) 58:77-87.

Vracko $R$, Thorning D, Fredrickson RG. Connective tissue cells in healing rat myocardium. A study of cell reactions in rhythmically contracting environment.. Am J Pathol (1989) 134:993-1006.

Vyalov S, Desmouliere a, Gabbiani G. GM-CSF-induced granulation tissue formation: relationships between macrophage and myofibroblast accumulation. Virchows Arch B Cell Pathol (1993) 63:231-239. 

TENASCIN AND FIBRONECTIN EXPRESSION IN HEALING HUMAN MYOCARDIAL SCARS

Willems IEMG, Arends JW, Daemen MJAP. submitted 


\section{SUMMARY}

Fibronectin as well as tenascin are matrix proteins known to be present in early experimental woundhealing, and are suggested to function as a meshwork essential to the organization of other matrix proteins such as collagen. Ass only limited data are available regarding early matrix changes in human myocardial infarction, we studied the presence of tenascin and fibronectin protein in human myocardial infarctions of different postinfarction times ( 6 hours to 17 years old). The presence of both proteins was evaluated by immunohistochemistry, using a monoclonal antibody recognizing tenascin and a polyclonal antibody recognizing fibronectin.

In normal myocardium fibronectin was found in the subendothelial space in arterioles, venules and capillaries. Tenascin was not present in normal myocardium. While fibronectin was already demonstrated in the ischemic cardiomyocytes within 1 day, tenascin was found after 4 to 6 days postinfarction and was located at the margin of the infarction area. Tenascin expression shifted from the margin to the centre of the infarction area, where it could be found 2-3 weeks postinfarction. At a postinfarction time of more than 4 weeks the scar tissue consisted of collagen fibers, with sparse (myo)fibroblasts. At that time tenascin as well as fibronectin expression had disappeared. Another interesting observation in this study was the presence of tenascin but not fibronectin surrounding hibernating cardiomyocytes.

In conclusion, tenascin as well as fibronectin are present during earty woundhealing after myocardial infarction in humans. Tenascin shifts from the margin of the infarction to the centre. In addition, tenascin but not fibronectin is present surrounding hibernating cardiomyocytes.

\section{INTRODUCTION}

Myocardial woundhealing shares characteristics with dermal woundhealing, such as collagen deposition and angiogenesis (Bouchardy \& Majno, 1974; Ehrlich, 1988). There are however also differences. For example myofibroblasts remain present in myocardial woundhealing even 17 years postinfarction, in contrast to dermal woundhealing where they disappear after approximately 2 weeks (Darby et al., 1990, chapter 3 of this thesis). Fibronectin and tenascin are two extracellular matrix proteins known to be present during dermal woundhealing (ffrench- 
Constant et al., 1989; Juhasz et al., 1993; Luomanen \& Virtanen, 1993). Since only limited data are available on the expression of fibronectin and tenascin in human myocardial woundhealing, we focus on these 2 extracellular matrix proteins in the present study. Early matrix proteins are suggested to function as a meshwork for the deposition and adhesion of other matrix proteins, that appear later, such as collagen (Kurkinen et al., 1980; Matsumoto et al., 1994). One of the most extensively studied early matrix proteins is fibronectin, of which multiple isoforms are present, arising by alternative splicing. The protein is produced in a cellular form (c-FN) which is synthesized and secreted locally by interstitial cells (Vartio et al., 1987) and a plasma form ( $\mathrm{p}-\mathrm{FN}$ ), synthesized and secreted by hepatocytes (Oh et al., 1981; Tamkun \& Hynes, 1983).

$\mathrm{C}$-FN and p-FN are both demonstrable in dermal wounds and precede other extracellular matrix proteins like collagen (ffrench-Constant et al., 1989). In the normal young and adult rat myocardium, $\mathrm{p}-\mathrm{FN}$ is present in the subendothelium in atria as well as ventricles (Mamuya \& Brecher, 1992). Both fibronectins have been identified immunohistochemically in experimental myocardial infarction in rodents (Casscells et al., 1990; Knowlton et al., 1992). Plasma fibronectin is found in the necrotic cardiomyocytes, while cellular fibronectin is present in the newly formed extracellular matrix (Shekhonin et al., 1990). The presence of total fibronectin, i.e. plasma- and cellular fibronectin, has also been demonstrated in human hearts two weeks postinfarction, which was the only time point studied (Shekhonin et al., 1988). Fibronectin interacts with other matrix proteins such as tenascin. This $320 \mathrm{kD}$ macromolecule is expressed during embryogenesis (Garcia-Martinez et al., 1990; Truong et al., 1994), and in pathological conditions such as chronic liver disease, prostatic hyperplasia and several carcinomas (Ibrahim et al., 1993; Jaskiewicz et al., 1993; Meiners et al., 1993). In both experimental and human dermal woundhealing tenascin is detectable after 1-2 days and remains present for 1 month (Betz et al., 1993; Luomanen \& Virtanen, 1993). In human dermal and rat tracheal wound healing tenascin expression increases in combination with (cellular) fibronectin (Juhasz et al., 1993; Kanno \& Fukuda, 1994). Since there are only limited data on fibronectin and no data on tenascin in human myocardial woundhealing, we studied the expression of both early matrix proteins in human myocardial infarctions with different postinfarction times, to evaluate whether their expression pattern differs from that in dermal woundhealing. 

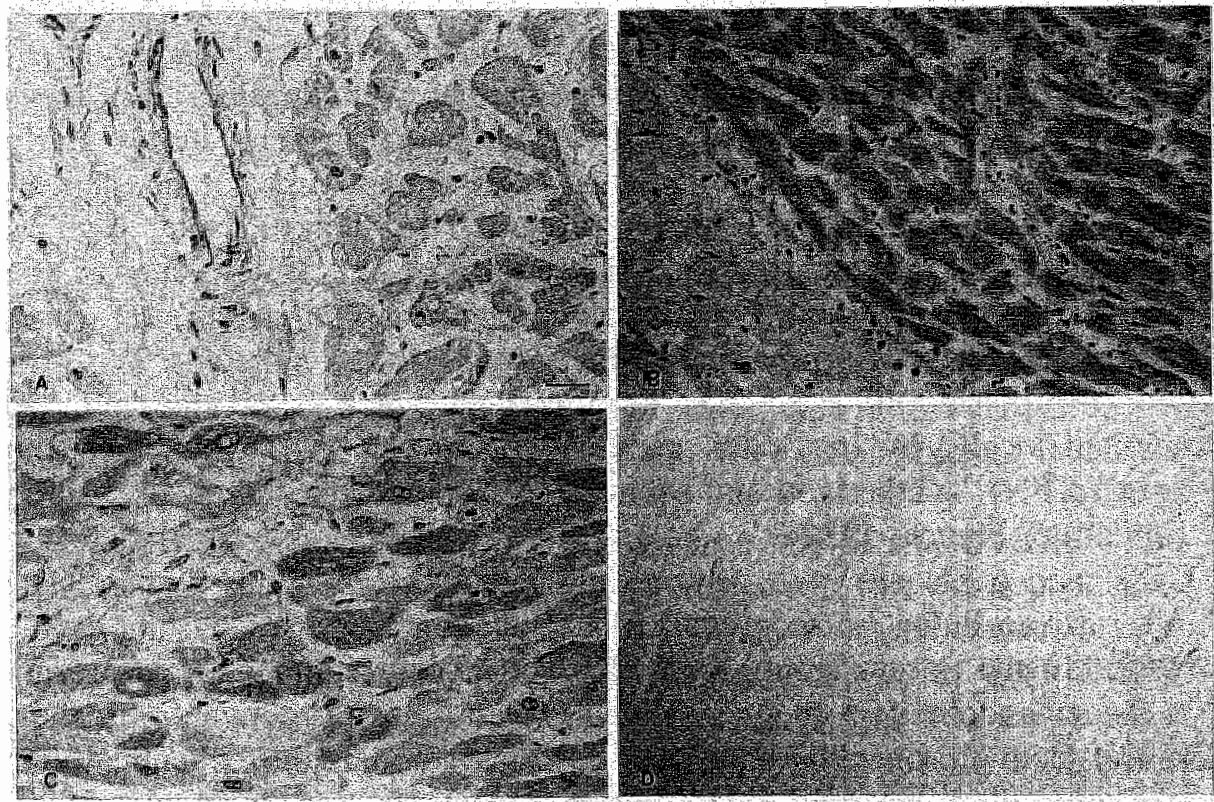

Figure 1 Photomicrograph of human myocardial infarction immunohistochemicallly treated with anti-fibronectin (FN, bar is $50 \mu \mathrm{m}$ ). A: Normal myocardium. FN is present in the subendothelial space; B: Human myocardium 24 hours after infarction. FN is present in the ischemic cardionyocytes; C: Human myocardium 1 to 2 weeks after infarction. FN is present in the cardiomyocytes surrounding the infarcted area, in a patchy distribution; D: Human myocardium $>4$ weeks postinfarction. FN is no longer present in the scar tissue.

Legends to figures, next page.

Figure 2 Photomicrograph of human myocardial infarction immunohistochemically treated with anti-tenascin (bar is $50 \mu \mathrm{m}$ ). A: Normal myocardium. Tenascin is not present; B: Transmural infarction after $<\mathbb{1}$ week with tenascin deposition at the border of the infaretion; C: Patchy myocardial infarction after 1 to 2 weeks. Tenascin is present in the total infarcted area; D: Human myocardial scar tissue ( $>4$ weeks postinfarction) without any tenascin expression.

Figure 3 Photomicrograph of hibernating human myocardium (bar is $50 \mu \mathrm{m}$ ); $\mathbf{A}$ : Hibernating cardiomyocytes surrounded by tenascin; B: Hibernating cardiomyocytes treated with anti-FN. No FN is present. 

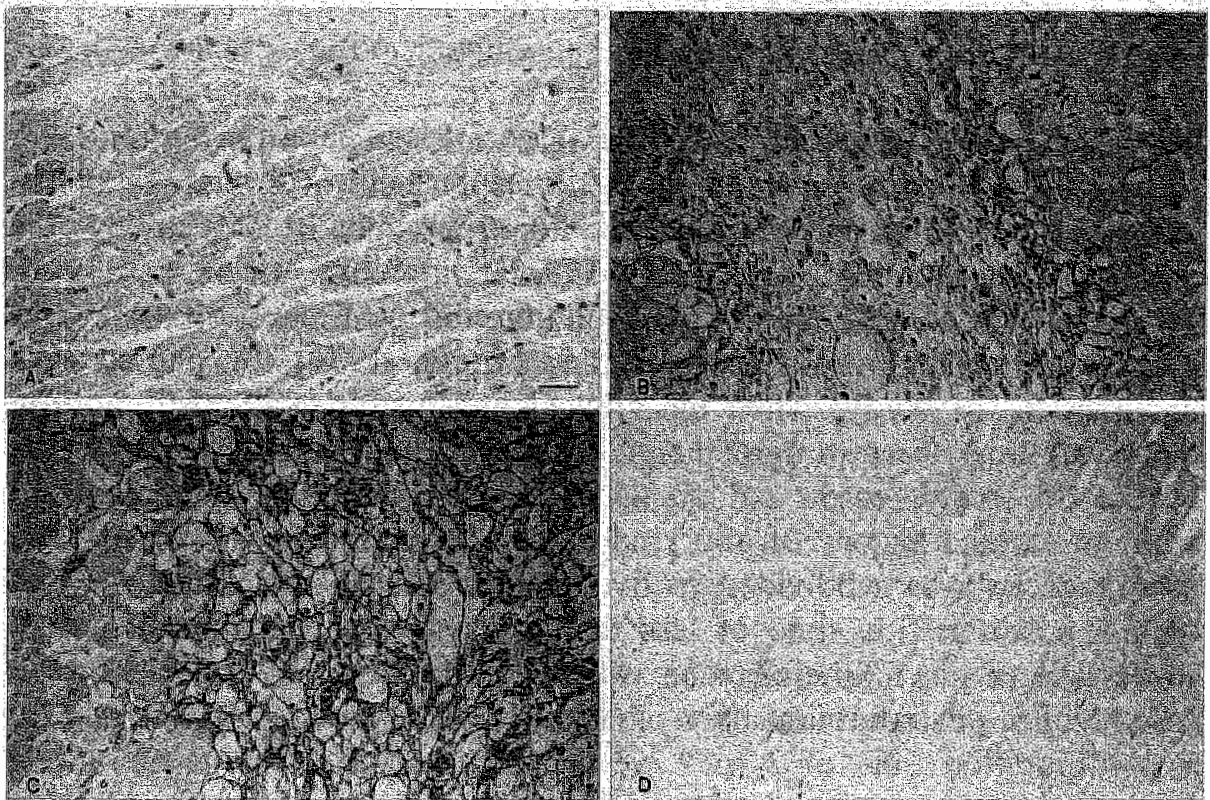

\section{Figure 2}
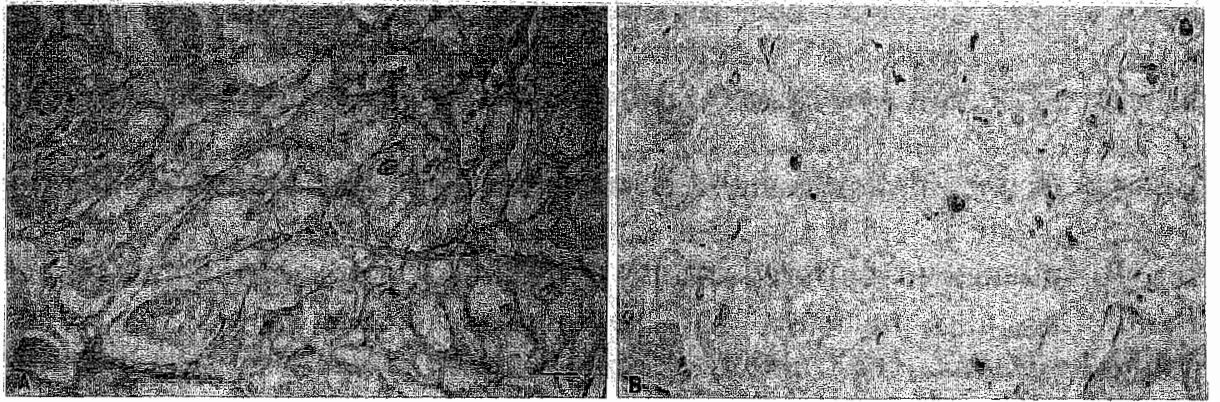

\section{Figure 3}




\section{MATERIALS AND METHODS}

\section{Source of tissue}

Tissue blocks of human myocardial infarctions, obtained during autopsy, were retrieved from the archives of the Department of Pathology of the University Hospital of Maastricht. For inclusion in this study the duration from the first signs of myocardial infarction to the demise of the patient had to be known. In addition the postinfarction time was estimated histologically (Bouchardy \& Majno, 1974). A patient was included in the study, when the clinical and histological postinfarction (survival) time were in agreement. Based on these criteria a total number of 35 infarct cases and an additional non-infarcted control group with no cardiac history of any kind (group $0 ; n=5$ ), were studied. The infarct group was subdivided in five groups. Group 1 included 5 cases with a postinfarction time of less than 2 days, group 2 consisted of 6 cases with a postinfarction time of 2 to 7 days, group 3 included 10 cases with a postinfarction time of 1 to 2 weeks, group 4 six cases with a postinfarction time of 2 to 4 weeks and group 5 eight cases with a postinfarction time exceeding 4 weeks.

\section{Immunohistochemistry}

Tissue blocks from the infarcted myocardium were fixed in $4 \%$ neutral buffered formaldehyde and embedded in paraffin according to routine procedures. After deparaffinization, $4 \mu \mathrm{m}$ thick sections were washed $3 \mathrm{x}$ $5 \mathrm{~min}$ in Tris buffered saline (TBS). Endogenous peroxidase activity was blocked by $0.3 \% \quad \mathrm{H}_{2} \mathrm{O}_{2}$ in methanol for $15 \mathrm{~min}$ at room temperature. Before incubation with anti-tenascin (Tenascin monoclonal antibody, Eurodiagnostica, 1:50) for 30 minutes, the sections were boiled $\left(100^{\circ} \mathrm{C}\right.$ ) for 10 minutes in buffered citrate and cooled down during one hour. Parallel sections, incubated with anti-human fibronectin (FN polyclonal antibody, Sigma, 1:400), were pretreated with $0.1 \%$ pepsin (Boehringer) in $0.1 \mathrm{~N} \mathrm{HCl}, \mathrm{pH} 2.0$ for $30 \mathrm{~min}$ at room temperature. After incubation with the primary antibody the sactions were washed $3 \times 5$ min with TBS and incubated with horseradish peroxidase conjugated rabbit anti mouse antibodies (DAKO, dilution $1: 200$ ) for the slides treated with anti-tenascin. Swine anti rabbit antibodies (DAKO, dilution 1:500) were used for the slides treated with anti-fibronectin. Both these antibodies were incubated during $30 \mathrm{~min}$ at room temperature. After final washings with TBS, diaminobenzidine- $\mathrm{H}_{2} \mathrm{O}_{2}$ substrate was used to visualize the immunoreactivity for the anti-tenascin and anti-FN treated sections. To 
enhance the precipitation of the chromogen, $0.1 \mathrm{M}$ imidazole was added to the substrate. Before mounting, the sections were weakly counterstained with Mayer's haematoxylin.

As negative control, a section of an infarcted human myocardium (1-2 weeks) was used, which was treated only with horseradish peroxidase conjugated rabbit anti mouse antibodies (DAKO, dilution 1:200) or swine anti rabbit antibodies (DAKO, dilution 1:500) during 30 min at room temperature. Also here diaminobenzidine $-\mathrm{H}_{2} \mathrm{O}_{2}$ substrate was used as a chromogen. The sections were evaluated with the observer blinded to the clinical history.

\section{RESULTS}

\section{Group 0: Controls}

Fibronectin could be identified in the subendothelial area in capillaries venules and arterioles (fig. 1a). Tenascin could not be detected in normal human myocardium (fig. 2a).

\section{Group 1: 6-48h infarction}

In infarctions with a postinfarction time of about 12 hours, fibronectin was expressed in the cytoplasm of the cardiomyocytes in the infarcted area. The staining of fibronectin appeared to be more homogeneous in the cardiomyocytes with a postinfarction time of 24-48 hours (fig. 1b), compared to the wounds 12 hours after infarction (not shown). In the non-infarcted areas fibronectin remained present in the subendothelial region. Tenascin was not present 6-48 hours postinfarction (data not shown).

\section{Group 2: 2-7 days infarction}

In this period fibroblasts and myofibroblasts entered the healing infarct, and were surrounded by small amounts of extracellular matrix. This matrix contained fibronectin as well as tenascin, the latter after day 4 to 6 (fig. 2b). Tenascin was located at the margin of the infarcted area. Fibronectin also remained present in the necrotic cardiomyocytes in the infarcted area.

\section{Group 3: 1-2 weeks infarction}

In 1 to 2 weeks old infarctions, fibronectin was still found in the infarcted area in both the interstitium, and in the necrotic remains of the 
cardiomyocytes. The interstitial fibronectin co-localized with tenascin. The cardiomyocytes surrounding the formation of scar tissue also contained fibronectin. Its distribution, however was patchy (fig. 1c). In the non-transmural infarctions tenascin expression was present in the total infarcted area (fig. 2c). In the larger, transmural infarctions tenascin could still be identified at the border of the infarction. The amount of protein, however was increased, compared to the previous time-span (46 days).

\section{Group 4. 2-4 weeks infarction}

In the period from week 2 to 4 the staining pattern of fibronectin and tenascin was similar to the pattern described in group 3 (1-2 weeks postinfarction; fig. $1 \mathrm{c}$ and $2 \mathrm{c}$ ). The amount of both fibronectin and tenascin did not seem to have changed. The presence of tenascin in the transmural infarction had however shifted from the border of the infarction to its centre, surrounding the central area of necrosis, that was still observed in some extensive infarctions. In this necrotic area fibronectin remained present.

\section{Group 5: more than 4 weeks infarction}

In more than 4 weeks old infarctions the cellularity of the scartissue had decreased. This compact extracellular matrix did not contain fibronectin (fig. 1d) nor did it show tenascin (fig. 2d). The cardiomyocytes surrounding the scar tissue had lost their fibronectin contents as well. Fibronectin remained present in the subendothelium as in non-infarcted normal myocardium (fig. 1a).

In a large number of myocardial tissue specimens, the non-infarcted subendocardially arranged cardiomyocytes demonstrated large vacuoles within their cytoplasm, filled with glycogen (fig. 3a of chapter 5). These cardiomyocytes, designated in the literature as hibernating cardiomyocytes (Borgers et al., 1993) were surrounded by an extracellular matrix consisting of tenascin (fig. 3a) but not of fibronectin (fig. 3b).

\section{DISCUSSION}

The data on fibronectin localization in human myocardial scars, that are presented in this study, confirm the results of earlier studies in rat myocardium. In those studies total fibronectin, (plasma and cellular fibronectin), was present as early as 4 hours after myocardial infarction, 


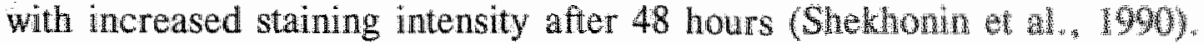
The early expression of fibronectin in the infarcted myocardiun is thought to influence the thrombotic, inflammatory, angiogenic and fibrotic processes involved in infarct healing (Casscells et al., 1990). The antibody used in the present study also recognizes both plasma and cellular fibronectin. In early human infarcts fibronectin protein was found in the cytoplasm of ischemic/necrotic cardiomyocytes in or surrounding the infarct (fig. $. \mathrm{b}, \mathrm{c})$. In a few days old infarcts fibronectin was not only present in the necrotic cardiomyocytes but also in the extracellular matrix of the newly formed scar. Although it is impossible to distinguish plasma and cellular fibronectin with the antibody used in the present study, it is conceivable that the fibronectin in the cytoplasm of ischemic/necrotic cardiomyocytes is plasma fibronectin (Knowlton et al., 1992). The internalization of plasma fibronectin in the cardiomyocytes occurs through loss of the integrity of the plasma membrane in ischemic cardiomyocytes (Holmbom et al., 1993). The fibronectin in the extracellular matrix found in 3 days to 4 weeks old newly formed scars could at least partially consist of the cellular form. This suggestion is based on the findings in an experimental model of myocardial infarction in the rat, where increased mRNA levels of cellular fibronectin were found in the infarct (Shekhonin et al., 1990). Increased mRNA levels are associated with increased cellular filbronectin protein deposition in the infarct (Knowlton et al., 1992). Cardiac fibroblasts in the scar tissue are potential producers of this cellular fibronectin (Samuel et al., 1991).

This study shows that (Cellular) fibronectin is only transiently present during myocardial woundhealing. The absence of fibronectin in mature myocardial scartissue, confirms the suggestion that the protein provides an early and temporary matrix for the deposition and remodeling of other matrix proteins such as collagen (Knowlton et al., 1992).

Tenascin was also expressed in early myocardial scars, as demonstrated in the present study (fig. 2). Tenascin was not found in normal myocardium and immunoreactivity appeared 4-6 days after myocardial infarction. The protein remained present up to 1 month after myocardial infarction. Its expression pattern resembled the pattern found for the extracellular fibronectin. The transient expression of tenascin in woundhealing is comparable to the expression of fibronectin (Juhasz et al., 1993; Kanno \& Fukuda, 1994). This may suggest a similar role for tenascin, as for fibronectin, in formation an early meshwork essential for the organization of the other, more tensile proteins (Kurkinen et al., 
1980). Another distinct observation of this study is the presence of tenascin and not fibronectin surrounding so-called hibernating cardiomyocytes (fig. 3). Hibernation of myocardium has been described for several years and refers to the presence of persistent left ventricular dysfunction at rest, which is associated with a reduced coronary blood flow (Tubau \& Rahimtoola, 1992). Although contractility is impaired, the cardiomyocytes remain vital. The structure of hibernating cardiomyocytes appears to have changed from a functional state (rich of contractile filaments) to a surviving state (rich of glycogen) (Borgers et all., 1993). The glycogen in the cytoplasm of the cardiomyocyte is present in large vacuoles. This glycogen can be visualized by a histochemical Periodic Acid Schiff staining (PAS; fig. 3a), in which the glycogen within the vacuoles stains red. Recent studies indicate an increased content of extracellular matrix in human hibernating myocardium (Maes et al., 1994; Ausma et al., 1995). The present study demonstrates that tenascin is one constituent of this extracellular matrix. Total fibronectin was not detectable surrounding the hibernating cardiomyocytes. The absence of fibronectin in the hibernating cardiomyocytes supports the idea that these cells are still viable, and have an intact plasma membrane. The difference in expression of tenascin and fibronectin in the matrix surrounding the hibernating cardiomyocytes may point to the existence of different functions of these two proteins. This has also been suggested by other authors that showed a different expression of both proteins in time, during a model of woundhealing in the rat trachea (Kanno \& Fukuda, 1994).

Comparison of the present observations to data documented on experimental as well as human dermal woundhealing demonstrates similarities between the two tissue repair patterns. The early matrix proteins, fibronectin and tenascin, are transiently present in both types of woundhealing. One obvious difference however is the sustained presence of tenascin surrounding the hibernating myocardium. An entity, comparable to hibernation however is not present in dermal woundhealing.

The regulation of early matrix proteins has been of great interest in literature. Several local, as well as circulating factors play a role in this regulation. In an earlier study on human myocardial woundhealing, we postulated that the persistent presence of myofibroblasts could be the result of stretch (chapter 3 of this thesis). It is conceivable that early extracellular matrix production is also influenced by stretch. Stretch of cardiomyocytes has been documented to induce autocrine release of 
angiotensin II (Sadoshima et al., 1993). Angiotensin II is one of the regulating factors of early matrix production. Cellular fibronectin expression can be modulated by a pressor dose of angiotensin II in rats. Fibronectin is expressed in the patchy areas of angiotensin II induced cardiomyocyte necrosis (Crawford et al., 1994). Fibronectin is produced in cultured myocardial fibroblasts and can be modulated by angiotensin II administration (Eghbali et al., 1989).

Next to mechanical and circulating factors local cytokines have to be considered in the regulation of early matrix production. In astrocytic extracellular matrix tenascin is observed and its amount can be enhanced by treatment with bFGF (Meiners et al., 1993). The increased amount of tenascin was associated a growth arrest of neurons, indicating that basic-fibroblast growth factor (bFGF) could have an anti-regenerative effect. In arterial smooth muscle cells the presence of splice variants of tenascin mRNA and protein could be induced by platelet derived growth factor BB (PDGF-BB) (LaFleur et al., 1994). Fibronectin expression however did not change.

Transforming growth factor- $\beta$ (TGF- $\beta$ ) is an important modulator of granulation tissue formation. TGF- $\beta$ has been demonstrated to induce the myofibroblast phenotype during woundhealing (Bachem et al., 1993; Desmouliere et al., 1993; Ronnov-Jessen \& Petersen, 1993). Myofibroblasts are present in experimental but also human myocardial woundhealing (chapter 3 of this thesis). Recent reports document increased expression of TGF- $\beta$, coinciding with increased expression of both fibronectin and tenascin in tumour stroma (Walker et al., 1994). Myocardial inflammation is found in TGF-B knockout mice leading to cardiopulmonary failure and death. Fibronectin infusion blocks this inflammatory response (Hines et al., 1994). TGF- $\beta$ is also present in human hibernating cardiomyocytes (chapter 5 of this thesis, fig 3 of chapter 5), and may therefore also regulate the production of matrix proteins such as tenascin, surrounding these cells.

In conclusion tenascin as well as fibronectin are observed during woundhealing after human myocardial infarction. The proteins remain present until 1 month postinfarction. This transient expression of both proteins support the suggestion that fibronectin as well as tenascin form an early and temporary matrix necessary for the organization of later appearing matrix proteins such as collagen. In addition tenascin, and not fibronectin is found surrounding so-called hibernating cardiomyocytes. This observation may suggest possible functional differences between both proteins. 


\section{REPERENCES}

Ausma JMS, Schatart $G$, Thone $F$; Shivalkar $B$, Flameng $W$, Depre $C$, Vanoverschelde $J-L$, Ramatekers $F$, Borgers $M$. Chronic ischemic viable myocardium in man: aspects of dedifferentiation. Cardiovasc Pathol (1995) 4:29-37.

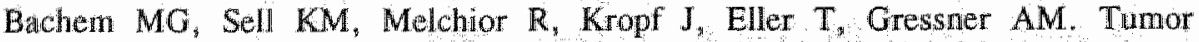
necrosis factor alpha (TNF-alhpa) and transforming growth factor beta-1 (TGF-beta-1) stimulate fibronectin synthesis and the transdifferentiation of fatstoring cells in the rat liver into myofibroblasts. Virchows Arch B Cell Pathol (1993) 63:123-130.

Betz $\mathrm{P}$, Nerlich A, Tubel J, Penning R, Eisenmenger W. Localization of tenascin in human skin wounds, an immunohistochemical study. Int J Legal Med (1993) 105:325-328.

Borgers M, De Nollin S, Thone F, Wouters $L$, van Vaeck L, Flameng W. Distribution of calcium in a subset of chronic hibernating myocardium in man. Histochem J (1993) 25:312-318.

Bouchardy B, Majno G. Histopathology" of early myocardial infarcts. A new approach. Am J Pathol (1974) 74:301-330.

Casscells W, Kimura H, Sanchez JA, Yu Z-X, Ferrans VJ. Immunohistochemical study of fibronectin in experimental myocardial infarction. Am J Pathol (1990) 137:801-810.

Crawford DC, Chobanian AV, Brecher P. Angiotensin II induces fibronectin expression associated with cardiac fibrosis in the rat. Circ Res (1994) 74:727739.

Darby 1, Skalli $O$, Gabbiani $G$. Alpharsmooth muscle actin is transiently expressed by myofibroblasts during experimental wound healing. Lab Invest (1990) $63: 21-29$

Desmoulliere A, Geinoz A, Gabbiani F, Gabbiani G. Transforming growth factorbeta 1 induces alpha-smooth muscle actin expression in granulation tissue myofibroblasts and in quiescent and growing cultured fibroblasts. I Cell Biol (1993) 122:103-111.

Eghbali $M$, Eghbali $M$, Robinson TF, Seifter S, Blumenfeld $O O$. Collagen accumulation in heart ventricles as a function of growth and aging. Cardiovasc Res (1989) 23:723-729.

Ehrlich HP. Wound closure: evidence of cooperation between fibroblatsts and collagen matrix. Eye (1988) 2:149-157.

ffrench-Constant $\mathrm{C}$, van de Water $\mathrm{L}$, Dworak HF, Hynes RO. Reappearance of an embryonic pattern of fibronectin splicing during wound healing in the adult rat. J Cell Biol (1989) 109:903-914.

Garcia-Martinez V, Sanchez-Quintana D, Hurle JM. Histogenesis of the semilunar valves: an immunohistochemical analysis of tenascin and type-I collagen distribution in developing chick heart valves. Cell Tissue Res (1990) 259:299304.

Hines KL, Kulkarni AB, McCarthy JB, Tian H, Ward JM, Christ M, McCarntneyFrancis NL, Furcht LT, Karlsson S. Synthetic fibronectin peptides interupt 
inflammatory cell infiltration in transforming growth factor $\beta 1$ knockout mice. Proc Natl Acad Sci USA (1994) 91:5187-5191.

Holmborn B, Naslund U, Eriksson A, Virtanen I, Thomell LE. comparison of triphenyltetrazolium chloride (TTC) staining versus detection of fibronectin in experimental myocardial infarction. Histochem (1993) 99:265-275.

Ibrahim SN, Lightner VA, Ventimiglia JB, Ibrahim GK, Walther GK, Bigner DD, Humphrey PA. Tenascin expression in prostatic hyperplasia, intraepithelial neoplasia, and carcinoma. Hum Pathol (1993) 24:982-989.

Jaskiewicz K, Chasen MR, Robson SC. Differential expression of extracellular matrix proteins and intergrins in hepatocellular carcinoma and chronic liver disease. Anticancer Res (1993) 13:2229-2237.

Juhasz I, Murphy GF, Yan HC, Herlyn M, Albelda SM. Regulation of extracellular matrix proteins and integrin cell substratum adhesion receptors on epithelium during cutaneous human woundhealing in vivo. Am $J$ Pathol (1993) 143:1458-1469.

Kanno S, Fukuda $Y$. Fibromectin and tenascin in rat tracheal wound healing and their relation to cell proliferation. Pathol Int (1994) 44:96-106.

Knowiton AA, Connely CM, Romo GM, Mamuya W, Apstein CS, Brecher P. Rapid expression of fibronectin in the rabbit heart after myocardial infarction with and without reperfusion. J Clin Invest (1992) 89:1060-1068.

Kurkinen $M$, Vaheri A, Roberts PJ, Stenman S. Sequential appearance of fibronectin and collagen in experimental granulation tissue. Lab Invest (1980) $43: 47-51$.

LaFleur DW, Fagin JA, Forrester JS, Rubin SA, Sharifi BG. Cloning and characterization of alternatively spliced isoforms of rat tenascin. Platelet derived growth factor BB markedly stimulates expression of spliced variants of tenascin mRNA in arterial smooth muscle cells. J Biol Chem (1994) 269:20757-20763.

Luomanen M, Virtanen T. Distribution of tenascin in healing incision, excision and laser wounds. J Oral Pathol Med (1993) 22:41-45.

Maes A, Flameng W, Nuyts J, Borgers M, Shivalkar B, Ausma J, Bormans G, Schiepers C, de Roo M, Mortelmans L. Histological alterations in chronically hypoperfused myocardium. Correlations with PET findings. Circulation (1994) 90:735-745.

Mamuya WS, Brecher P. Fibronectin expression in the normal and hypertrophic rat heart. J Clin Invest (1992) 89:392-401.

Matsumoto K, Saga Y, Ikemura $T$, Sakakura T, Chiquet-Ehrismann R. The distribution of tenascin- $\mathrm{X}$ is distinct and often reciprocal to that of tenascin-C. J Cell Biol (1994) 125:483-493.

Meiners S, Marone M, Rittenhouse JL, Geller HM. Regulation of astrocytic tenascin by basic fibroblast growth factor. Dev Biol (1993) 160:480-493.

Oh E, Pierschbacher M, Ruoslati E. Deposition of plasma fibronectin in tissue. Proc Nat」 Acad Sci USA (1981) 78:32.8-3221.

Ronnov-Jessen $\mathbb{L}$, Petersen OW. Induction of alpha-smooth muscle actin by transforming growth factor-beta 1 in quiescent human breast gland fibroblasts. Implications for myofibroblast generation in breast neoplasia. Lab Invest 
(1993) 68:696-707.

Sadoshima JI, $X u Y$, Slayter HS, Izumo S. Autocrine release of Angiotensin II mediates stretch-induced hypertrophy of cardiac myocytes in vitro. Cell (1993) 75:977-984.

Samuel JL, Barrieux A, Dufour S, Dubus I, Contard F, Koteliansky V, Farhadian $F$, Marotte F. Thiery J-P, Rappaport L. Accumulation of fetal Fibronectin mRNA during the development of rat cardiac hypertrophy induced by pressure overload. J Clin Invest (1991) 88:1737-1746.

Shekhonin BV, Domogatsky SP, Idelson GL, Koteliansky VE. Participance of fibronectin and various collagen types in the formation of fibrous extracellular matrix in cardiosclerosis. $J$ Mol Cell Cardiol (1988) 20:501-508.

Shekhonin BV, Guriev SB, Irgashev SB, Koteliansky VE. Immunofluorescent identification of fibronectin and fibrinogen/fibrin in experimental myocardial infarction. J Moll Cell Cardiol (1990) 22:533-541.

Tamkun JW, Hynes RO. Plasma fibronectin is produced by hepatocytes. J Biol Chen (1983) 258:4641-4646.

Truong LD, Pindur J, Barrios R, D'Agati V, Lechago J, Suki W, Majesky M. Tenascin is an important component of the glomerular extracellular matrix in normal and pathologic conditions. Kidney Int (1994) 45:201-210.

Tubau JF, Rahimtoola SH. Hibernating myocardium; a historical perspective. Cardiovasc Drugs Ther (1992) 6:267-271.

Vartio $T$, Laitinen $L$, Narvanen $O$, Cutolo $M$, Thornell LE, Zardi $L$, Virtanen I. Differential expression of the ED sequence-containing of cellular fibronectin in embryonic and adult human tissues. J Cell Sci (1987) 88:419-430.

Walker RA, Dearing SJ, Gallacher B. Relationship of transforming growth factor $\beta 1$ to extracellular matrix and stromal infiltrates in invasive breast carcinoma. Br J Cancer (1994) 69:1160-1165. 
TRANSFORMING GROWTH FACTOR B EXPRESSION IN HEALING HUMAN MYOCARDIAL SCARS

Willems IEMG, Janssen AMH, Arends JW, Daemen MJAP. submitted 


\section{SUMMARY}

Since TGF-3 is an important mediator in fibrosis and tissue repair, we studied the expression of TGF-B protein in human myocardial infarctions of different postinfarction times (6 hours to 17 years old) with an antibody that identifies TGF- $\beta 1,2$ and 3. In normal, non-infarcted hearts, $T G F-\beta$ was present in cardiomyocytes, neurons, vascular smooth muscle cells, endothelial cells and non vascular spindle shaped cells. Six hours postinfarction the ischemic cardiomyocytes had lost TGF-B protein. Inflammatory cells infiltrating the infarcted area at 24 hours, did contain TGF- $\beta$. A portion of the myofibroblasts expressing $\alpha$-smooth muscle actin (ASMA), which appeared 4-6 days postinfarction also contained $T G F-\beta$. The amount of TGF- $\beta$ in these myofibroblasts decreased in mature scar tissue. No TGF- $\beta$ was present in the collagen fibers of mature scars in contrast to scar tissue 1-2 weeks postinfarction.

In a large number of myocardial tissue specimens hibernating cardiomyocytes were present in the non-infarcted subendocardial area. These cells appeared to contain TGF- $\beta$ protein in their cytoplasm.

In conclusion TGF- $\beta$ is present in normal human myocardium and is absent in ischemic cardiornyocytes, but it remains present in hibernating myocardium. TGF- $\beta$ is present in the healing infarction in the inflammatory cells and later in the (myo)fibroblasts. The coexpression of $T G F-\beta$ and ASMA in myofibroblasts at least supports the suggestion that $T G F-\beta$ is involved in the regulation of myofibroblast phenotype expression as is seen in dermal woundhealing.

\section{INTRODUCTION}

Transforming growth factor- $\beta$ (TGF- $\beta$ ) has evolved as the key cytokine in woundhealing and tissue fibrosis in different organs (Pierce et al., 1991; Bachem et al., 1993; Border \& Noble, 1994). This 25 kilodalton homodimer is present in nearly all cells and tissues. Its action, as of most cytokines, depends on the interaction with other cytokines and the physiological state of the target cell and the extracellular matrix (Long et al., 1993; Nishida et al., 1993).

TGF-B modulates the phenotype of fibroblasts into myofibroblasts as has been shown in cultured human breast fibroblasts (Ronnov-Jessen \& Petersen, 1993) and in experimental dermal woundhealing in vitro and in vivo (Desmouliere et al., 1993). No other cytokine investigated so far 
has this capacity (Desmouliere et al., 1992). Myofibroblasts also appear during woundhealing after myocardial infarction, as has been shown in animals as well as in humans (Vracko et al., 1989; Leslie et al., 1991; Vracko \& Thorning, 1991, chapter 3of this thesis). It is therefore tempting to hypothesize that TGF-B is involved in the induction of the myofibroblast phenotype during infarct healing.

TGF- $B$ is present in rodent myocardium and its contents increase after rat myocardial infarction (Thompson et al., 1988; Sun et al., 1993). No data are available on the presence of TGF- $\beta$ in the human heart, neither in normal nor in infarcted myocardium.

In this study the presence of TGF- $B$ in normal and infarcted human myocardium was studied by immunohistochemistry. Co-localisation of TGF-B and $\alpha$-smooth muscle actin, a marker for myofibroblasts (Skalli et al., 1986) was investigated in human hearts with different postinfarction times.

\section{MATERIALS AND METHODS}

Source of tissue

Tissue blocks of human myocardial infarctions, obtained during autopsy, were retrieved from the archives of the Department of Pathology of the University Hospital of Maastricht. For inclusion in this study the duration from the first signs of myocardial infarction to the demise of the patient had to be known. In addition the postinfarction time was estimated histologically (Bouchardy \& Majno, 1974). A patient was included in the study, when the clinical and histological postinfarction (survival) time were in agreement. Based on these criteria a total number of 35 infarct cases and an additional non-infarcted control group with no cardiac history of any kind (group $0 ; n=5$ ), were studied. The infarct group was subdivided in five groups. Group 1 included 5 cases with a postinfarction time of less than 2 days, group 2 consisted of 6 cases with a postinfarction time of 2 to 7 days, group 3 included 10 cases with a postinfarction time of 1 to 2 weeks, group 4 six cases with a postinfarction time of 2 to 4 weeks and group 5 eight cases with a postinfarction time exceeding 4 weeks.

\section{Immunohistochemistry}

Tissue blocks from the infarcted myocardium were fixed in $4 \%$ neutral buffered formaldehyde and embedded in paraffin according to routine 
procedures. After deparaffinization, $4 \mu \mathrm{m}$ thick sections were washed $3 \mathrm{x}$ $5 \mathrm{~min}$ in Tris buffered saline (TBS). Endogenous peroxidase activity was blocked by $0.1 \% \mathrm{H}_{2} \mathrm{O}_{2}$ in methanol for $20 \mathrm{~min}$ at room temperature and the sections were incubated during 45 minutes with anti TGF-B 1,2,3 (TGF 13 monoclonal antibody, Genzyme, dilution 1:10). Parallel sections were incubated with anti- $\alpha$ smooth muscle actin (ASMA monoclonal antibody, Sigma, dilution 1:4000). After incubation with the primary antibody the sections were washed $3 \times 5$ min with TBS and incubated with horseradish peroxidase conjugated rabbit anti mouse antibodies (DAKO, dilution 1:200) during $45 \mathrm{~min}$ at room temperature. After final washings with TBS, New Fuchsine substrate was used to visualize the immunoreactivity for the anti-TGF- $\beta$ treated sections. This red substrate was used, since pigment-loaded macrophages obscured the interpretation of the immunohistological findings in early myocardial infarctions when the diaminobenzidine- $\mathrm{H}_{2} \mathrm{O}_{2}$ substrate was used. Diaminobenzidine- $\mathrm{H}_{2} \mathrm{O}_{2}$ substrate was used in the anti-ASMA treated sections. To enhance the precipitation of the latter chromogen, 0.1M imidazole was added to the substrate. Before mounting, the sections were weakly counterstained with Mayer"s haematoxylin.

As negative control, a section of a non infarcted human myocardium was used, which was treated only with horseradish peroxidase conjugated rabbit anti mouse antibodies (DAKO, dilution 1:200) during 45 min at room temperature, and followed by New Fuchsine substrate or diaminobenzidine- $\mathrm{H}_{2} \mathrm{O}_{2}$ substrate. The sections were evaluated with the observer blinded to the clinical history.

\section{RESULTS}

\section{Group 0: Controls}

TGF- $\$$ was present in the cytoplasm of all cardiomyocytes. The staining pattern was of equal intensity, when comparing cardiomyocytes with each other (Fig la). The cytoplasm of endothelial cells of both vessels and endocardium contained TGF $-\beta$, as did pericardial neuronal tissue. In arterioles, TGF-B could be demonstrated in smooth muscle cells. Interstitial cells in normal, non-infarcted myocardium consist of fibroblasts, endothelial cells and pericytes. Although the exact cell type is difficult to discern, at least a fraction of the fibroblasts did contain TGF-B. Comparable staining patterns were found in the non-infarcted tissue of all infarct groups. 


\section{Group 1: 6-48h infarction}

In infarctions with a postinfarction lime of about 12 hours, cardiomyocytes in the infarcted area had lost their cytoplasmic TGF-13 staining pattern. The viable cardiomyocytes surrounding the infarcted area, still contained TGF-B (Fig (b). The intensity of immunoreactivity did not seem to be increased. Twentyfour hours postinfarction, inflammatory cells predominantly consisting of neutrophils, penetrated the infarct and a fraction of these inflammatory cells demonstrated strong immunoreactivity for TGF-B (data not shown).

\section{Group 2: 2-7 days infarction}

In this period the neutrophils disappeared, while fibroblasts and myofibroblasts entered the healing infarct. Starting from day 4 to 6 these spindle shaped cells were present in the granulation tissue at the interface of vital myocardium and infarct area and expressed TGF- $\beta$. At least a fraction of these cells coexpressed TGF- $\beta$ and $\alpha$-smooth muscle actin (data not shown, see also fig 2).

Newly formed endothelial cells in the wound also expressed TGF- $\beta$, as did the loosely textured extracellular matrix. Macrophages still present in the wound did also express TGF-B (Fig. 1c).

\section{Group 3: 1-2 weeks infarction}

In 1 to 2 weeks old non-transmural infarctions, the myofibroblasts were oriented parallel to adjacent surviving myocardial cells. A fraction of these cells also contained TGF-B. The cardiomyocytes surrounding the infarction still expressed cytoplasmic TGF-B.

The amount of TGF- $\beta$ in the extracellular matrix diminished, but TGF- $B$ was focally still present.

\section{Group 4: 2-4 weeks infarction}

In the period from week 2 to 4 the staining pattern was similar to the pattern described in group 3 (1-2 weeks postinfarction), although the number of TGF-13 positive (myo)fibroblasts decreased. Collagen fibers were already formed in the extracellular matrix, but did not contain TGF-B. The cardiomyocytes surrounding the scar tissue, but especially those that were encircled by dense collagen matrix demonstrated a more intense immunoreactivity for TGF-B (Fig 1d)

\section{Group 5: more than 4 weeks infarction}

In more than 4 weeks old infarctions the cellularity of the scartissue was 
decreased. The compact extracellular matrix did not contain detectable amounts of non-cellular TGF-B. A fraction of the myofibroblasts in this matrix still contained TGF-B. The fraction of TGF-B positive cells however seemed to be decreased, although TGF-B positive myofibroblasts persisted even in scar tissues with a postinfarction time of several years (Fig. 2).

In a large number of myocardial tissue specimens, the subendocardially arranged cardiomyocytes demonstrated large vacuoles within their cytoplasm. These vacuoles are filled with glycogen, which can be stained by a histochemical Periodic Acid Schiff stain (PAS). Glycogen is stained red by PAS (Fig. 3a). These cardiomyocytes, designated in the literature as hibernating cardiomyocytes (Borgers et al., 1993), appeared to contain TGF-B protein in their cytoplasm (Fig. 3b). The postinfarction time did not have a detectable effect on these cells.

\section{CONCLUSTON}

This is the first study showing TGF- $\beta$ expression in both normal and infarcted human hearts. It is of interest that the expression of TGF- $\beta$ in human infarcts changes over time. While ischemic cardiomyocytes loose their TGF- $\beta$ content, inflammatory cells infiltrating the infarct early after infarction contain TGF- $\beta$. Four to six days postinfarction TGF- $\beta$ expression re-occurs in the infarcted area, but now expression is found in myofibroblasts. In several other tissues of non-human species, the induction of the myofibroblasts phenotype by TGF-B has been demonstrated (Bachem et al., 1993; Desmouliere et al., 1993; RonnovJessen \& Petersen, 1993). The coexpression of TGF- $\beta$ and $\alpha$-smooth muscle actin as demonstrated in the present study supports the hypothesis that TGF-B is involved in the modulation of the myolibroblast phenotype in the human heart after infarction. Myofibroblasts share characteristics of both smooth muscle cells and fibroblasts, are present in woundhealing and have the possibility to contract (Gabbiani et al., 1971; Leslie et al., 1991). We recently described the presence of these myofibroblasts in human myocardial infarction. They appeared in 4-6 days postinfarction, and remained present even 17 years after infarction (chapter 3 of this thesis).

As not all myofibroblasts coexpressed both proteins (ASMA and TGFB), one cannot exclude a role for other cytokines. In fat storing cells in 
the liver myofibroblast transformation was observed after the administration of TNF- $\alpha$ as well as by TGF-B (Bachem et al, 1993). In dermal wounds however, myofibroblast transformation, was induced by TGF- 3 only, and not by TNF- $\alpha$ (Desmouliere et al., 1993).

The viable cardiomyocytes surrounding the scar maintained their expression of TGF-B. In 2-4 weeks old scars staining even appeared to be more intense (fig. Id). This apparent increase in TGF- $B$ content was first described by Thompson et al in rat myocardium (Thompson et al., 1988), but the significance of this increase is not clear. One possibility is that this increase is necessary for the production of sufficient extracellular matrix. Although the findings of this study do not demonstrate a collagen increase induced by TGF- $B$, the presence of TGF-B in the myocardial infarction and the increased amount of protein in the cardiomyocytes surrounding the infarction suggest a role for TGF- $\beta$ in the induction of collagen deposition in the infarct.

The last distinct observation in this study is the presence of TGF- $B$ in so-called hibernating cardiomyocytes. Hibernation of myocardium has been described for several years and refers to the presence of persistent left ventricular dysfunction at rest, which is associated with a reduced coronary blood flow (Tubau \& Rahimtoola, 1992). Although contractility is impaired, the cardiomyocytes remain vital. The structure of hibernating cardiomyocytes appears to have changed from a functional state (rich of contractile filaments) to a surviving state (rich of glycogen) (Borgers et al., 1993). The presence of TGF- $\beta$ in these hibernating cardiomyocytes may suggest that TGF- $B$ is involved in the modulation of hibernation. One hypothesis that can be put forward is, that TGF- $\beta$ influences hibernating myocardium through modulation of the production of (specifuc) extracellular matrix components. There are some data available, which show an increased content of extracellular matrix in human hibernating myocardium (Maes et al., 1994; Ausma et al., 1995). The type of protein present in the extracellular matrix has not been studied extensively. In the previous chapter however, tenascin is shown to be one of these proteins surrounding the hibernating cardiomyocytes (chapter 4 of this thesis). The sustained presence of TGF- $B$ in the hibernating cardiomyocytes may suggest a role for the cytokine in the production of the extracellular matrix during hibernation of the cardiomyocytes.

Several isoforms of TGF- $B$ have been identified in different species and three of them are present in humans. TGF-B1 and TGF-B3 are studied extensively. In rodents and dogs TGF- $\beta 1$ is present in the heart, with 
increased levels during development, growth and hypertrophy (Runyan et al., 1992; Villarreal \& Dillmann, 1992; Engelmann, 1993; MacLellan et al., 1993), but also after injury (Sun et al., 1993). TGF-Bl is implicated in tissue fibrosis (Border \& Noble, 1994) and TGF-B3 has been demonstrated in the heart during embryogenesis (Runyan et al, 1992). TGF-B2 has been identified in other human tissues such as the retina, where it has a beneficial effect on retinal defects and tissue repair. However, in the present study a pan TGF-B antibody was used, being the only available antibody to us. Identification of one or more of the isoforms is therefore not possible. This limitation should be kept in mind when interpreting the data of the present study.

A second limitation of this study, is also induced by the method (immunohistochemistry). TGF-B is normally present in a latent form and can be activated. Both the active and the latent form have a common antigenic binding side for the available antibodies. Therefore no difference can be made in latent and active TGF- $\beta$. It might be interesting to focus future studies on the localization and expression of TGF- $\beta$ receptors since only activated TGF- $\beta$ can bind to these receptors. All isoforms of TGF- $\beta$ are capable of binding to at least 3 receptors, which are present on virtually all cells, although specific knowledge of the myocardium is lacking. Type I and II receptors, which are serinethreonine kinases, are capable of signal transduction (Ross et al., 1993a, b). The type III receptor, a betaglycan, presents TGF- $\beta$ to other receptors, and has no signal pathway of its own (Lopez-Casillas et al, 1994). The type I receptor mediates the actions of TGF- $\beta$ on extracellular matrix production. Cell proliferation and growth is mediated by the type II receptor (Ebner et al., 1993). No data is available on the type of receptor responsible for induction of myofibroblast phenotype, nor the type of receptor present on hibernating cardiomyocytes.

In summary, TGF- $\beta$ is present in normal human myocardium and is absent in ischemic cardiomyocytes, but it remains present in hibernating myocardium. TGF-B is present in the healing infarction in the inflammatory cells an later in the (myo)fibroblasts. The coexpression of TGF- $B$ and ASMA in myofibroblasts supports the suggestion that TGF- $\beta$ is involved the regulation of myofibroblast phenotype expression as is seen in dermal woundhealing. 


\section{REFERENCES}

Ausma IMS, Schaart $G$, Thone $F$, Shivalkar B, Flameng $W$, Depre $C$, Vanoverschelde J-L, Ramaekers F, Borgers M. Chronic ischemic viable myocardium in man: aspects of dedifferentiation. Cardiovasc Pathol (1995) 4:29-37.

Bachem MG, Sell KM, Melchior R, Kropf J, Eller $T$, Gressner AM. Tumor necrosis factor alpha (TNF-alhpa) and transforming growth factor beta-1 (TGF-beta-1) stimulate fibronectin synthesis and the transdifferentiation of fatstoring cells in the rat liver into myofibroblasts. Virchows Arch B Cell Pathol (1993) 63:123-130.

Border WA, Noble NA. Transforming growth factor $\beta$ in tissue fibrosis. $N$ Engl $j$ Med (1994) 331:1286-1292.

Borgers M, De Nollin S, Thone F, Wouters L, van Vaeck L, Flameng W, Distribution of calcium in a subset of chronic hibernating myocardium in man. Histochem J (1993) 25:312-318.

Bouchardy B, Majno G. Histopathology of early myocardial infarcts. A new approach. Am J Pathol (1974) 74:301-330.

Desmouliere A, Rubbia-Brandt L, Grau G, Gabbiani G. Heparin induces alphasmooth muscle actin expression in cultured fibroblasts and in granulation tissue myofibroblasts. Lab Invest (1992) 67:716-726.

Desmouliere A, Geinoz A, Gabbiani F, Gabbiani G. Transforming growth factorbeta 1 induces alpha-smooth muscle actin expression in granulation tissue myofibroblasts and in quiescent and growing cultured fibroblasts. I Cell Biol (1993) $122: 103-111$.

Ebner R, Chen RH, Lawler S, Zioncheck T, Derynck R. Determination of type I receptor specificity by the type II receptors for TGF- $\beta$ or activin. Science (1993) 262:900-902.

Engelmann GL. Coordinate gene expression during neonatal rat heart development. A possible role for the myocyte in extracellular matrix biogenesis and capillary angiogenesis. Cardiovasc Res (1993) 27:1598-1605.

Gabbiani G, Ryan GB, Majno G. Presence of modified fibroblasts in granulation tissue and their possible role in wound contraction. Experientia (1971) $27: 549-550$.

Leslie KO, Taatjes DJ, Schwarz J, von Turkovich M, Low RB. Cardiac myofibroblasts express alpha smooth muscle actin during right ventricular pressure overload in the rabbit. Am J Pathol (1991) 139:207-216.

Long CS, Hartogensis WE, Simpson PC. Beta-adrenergic stimulation of cardiac non-myocytes augments the growth-promoting activity of non-myocyte conditioned medium. J Mol Cell Cardiol (1993) 25:915-925.

Lopez-Casillas F, Payne HM, Andreas JL, Massague T. Betaglycan can act as binding and GAG attachment sites. J Cell Biol (1994) 124:557 568.

MacLellan WR, Brand T, Schneider MD. Transforming growth factor-beta in cardiac ontogeny and adaptation. Circ Res (1993) 73:783-791. 

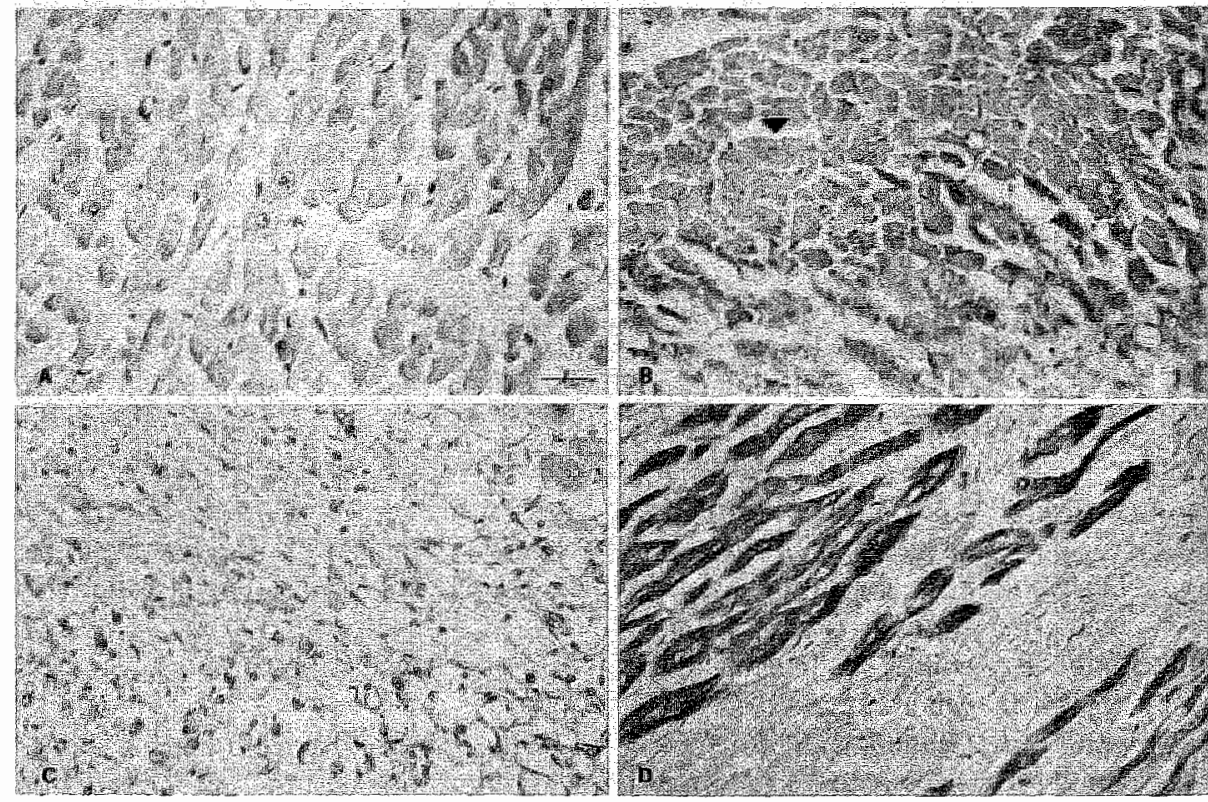

Figure 1 Photomicrograph of human myocardial infarction immunohistochemicallly treated with anti-TGF-B (bar is $50 \mu \mathrm{m}$ ). A: Normal myocardium. TGF- $\beta$ is present in all cardiomyocytes; B: Human myocardium 12 hours post infarction. Note the absence of TGF-B in the ischemic cardiomyocytes; $C$ : Human myocardium 1 to 2 weeks after infarction. The loosely textured extarcellular matrix contains TGF-B, as do the macrophages; D: Human myocardium $>4$ weeks postinfarction. The scar tissue is TGF- $B$ negative, and the surrounding cardiomyocytes show a more intense staining for TGF-B.

Legends to the figures, next page.

Figure 2 Photomicrograph of fibrous scar tissue, $>4$ weeks postinfarction. A: TGF- $\beta$; B: $\alpha$-smooth muscle actin (ASMA). Large photograph; identical area (bar is $100 \mu \mathrm{m}$ ). Insert photograph: fibroblast within this area ( $\vee$ bar is $10 \mu \mathrm{m}$ ).

Figure 3 Photomicrograph of hibernating cardionyocytes (bar is $50 \mu \mathrm{m}$ ). Within the vacuoles glyogen is present (A: PAS); TGF-B remains present in the cytoplasm of these cardiomyocytes $(B:$ TGF-B). 
Chapter 5

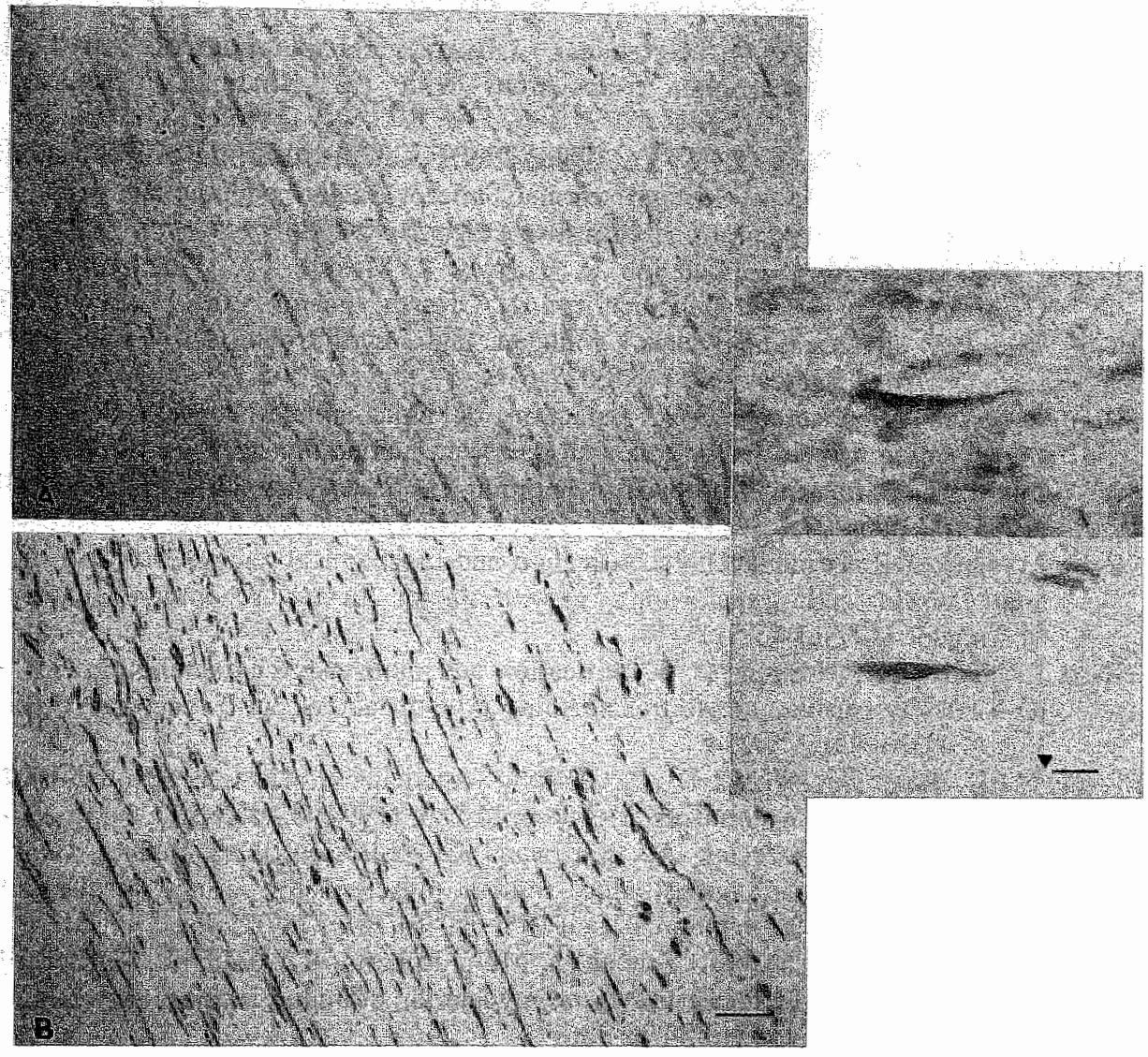

\section{Figure 2}

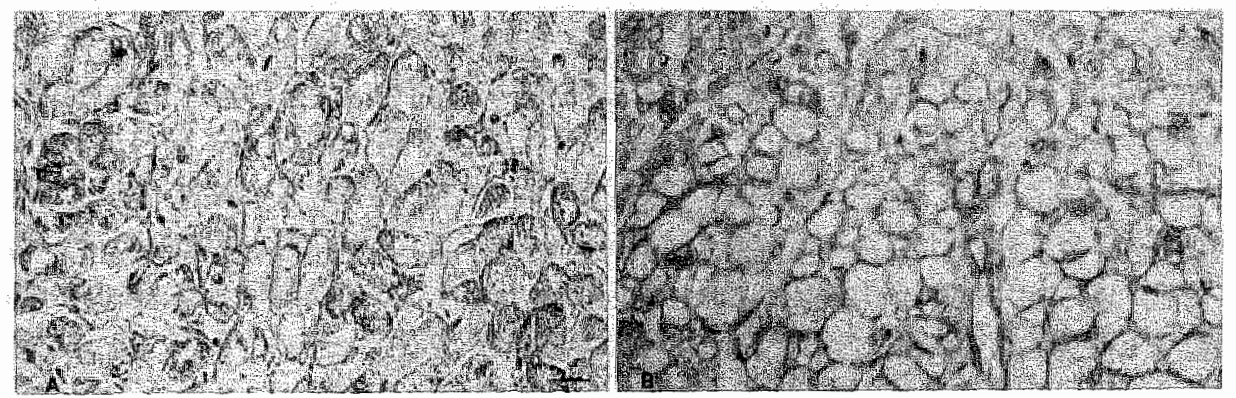

Figure 3 
Maes A, Flameng $W$, Nuyts $J$, Borgers $M$, Shivalkar B, Ausma $J$, Bormans G, Schiepers C, de Roo M, Mortelmans L. Histological alterations in chronically hypopperfused myocardium. Correlations with PET findings. Circulation (1994) $90: 735-745$.

Nishida M, Springhorn JP, Kelly RA, Smith TW. Cell-cell signaling between adult rat wentricular myocytes and cardiac microvascular endothelial cells in heterotypic primary culture. J Clin Invest (1993) 91:1934-1941.

Pierce GF, Vande Berg I, Rudolph R, Tarpley $J_{\text {, Mustoe TA. Platelet-derived }}$ Growth Factor-BB and Transforming Growth Factor-beta 1 selectively modulate glycosaminoglycans, collagen and myofibroblasts in excisional wounds. Am J Pathol (1991) 138:629-646.

Ronnov-Jessen L, Petersen OW. Induction of alpha-smooth muscle actin by transforming growth factor-beta 1 in quiescent human breast gland fibroblasts. Implications for myofibroblast generation in breast neoplasia. Lab Invest (1993) 68:696-707.

Ross I, Janero DR, Hreniuk D. Identification and biochemical characterization of a heart-muscle cell transforming growth factor beta- 1 receptor. Biochem Pharmacol (1993a) 46:511-516.

Ross J. Janero DR, Hreniuk D. Identification and molecular characterization of a high-affinity cardiomyocyte transforming growth factor-beta 2 receptor. FEBS Lett (1993b) 320:229-234.

Runyan RB, Potts JD, Weeks DL. TGF-beta 3 mediated tissue interaction during embryonic heart development. Mol Reprod Dev (1992) 32:152-159.

Skalli O, Ropraz P* Trzeciak A, Benzonana G, Gillessen D, Gabbiani G. A monoclonal antibody against alpha-smooth muscle actin: a new probe for smooth muscle differentiation. J Cell Biol (1986) 103:2787-2796.

Sun $₫ Z$, Li XY, Sporn MB, Schneider MD, Roberts R, Bolli R. Effect of transforming growth factor-beta 1 on myocardial stunning in the intact dog. J Mol Cell Cardiol (1993) 25:379-386.

Thompson NL, Bazoberry F, Speir EH. Transforming growth factor-beta $\mathbb{1}$ in acute myocardial infarction in rats. Growth Fact (1988) 1:91-99.

Tubau JF, Rahimtoola SH. Hibernating myocardium: a historical perspective. Cardiovasc Drugs Ther (1992) 6:267-271.

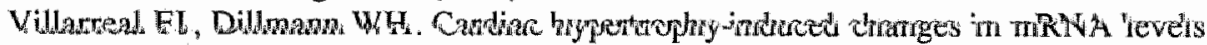
for TGF-beta 1, fibronectin, and collagen. Am J Physiol (1992) 262:H1861H1866.

Vracko $\mathrm{R}$, Thorning $\mathrm{D}$. Contractile cells in rat myocardial scar tissue. Lab Invest (1991) 65:214-227.

Vracko $\mathbb{R}$, Thorning D, Frederickson RG. Connective tissue cells in healing rat myocardium. A study of cell reactions in rhythmically contracting environment. Am J Pathol (1989) 134:993-1006. 
STRUCTURAL ALTERATIONS IN HEART VALVES DURING LEFT VENTRICULAR PRESSURE OVERLOAD IN THE RAT

Willems IEMG, Havenith MG, Smits JFM, Daemen MJAP. Lab Invest 1994 Jul;71(1):127-133 


\section{SUMMARY}

Heart valves are an important denominator of the function of the heart but detailed studies of structural alterations of heart valves following hemodynamic changes are lacking.

Structural alterations of heart valves, including DNA synthesis, collagen $m R N A$ and protein concentration were measured in heart valves of Wistar Kyoto rats with acute left ventricular pressure overload, created by intra-renal aortic ligation $(A L, n=18)$ as well as in heart valves of age-matched spontaneously hypertensive rats (SHR), a model of chronic hypertension $(n=18)$. SHAM aortic ligation and normal WKY's $(n=17$ and $n=17$ ) served as controls. All animals received 5'Bromo-2'deoxyUridine (BrdU), during the last 7 days of the experiment, in a dose of $10 \mathrm{mg} / \mathrm{kg}$.day.

The cumulative labeling fraction $(L F)$ in the mitral valve of $A L$ animals was $47.8 \pm 5.2 \%$ as compared to $9.4 \pm 2.6 \%$ in sham animals (mean \pm sem, $p<0.01$ ). The $L F$ in the aortic valve of $A L$ animals was $33.3 \pm 2.9 \%$ as compared to $7.7 \pm 0.7 \%$ in sham animals $(p<0.01)$. The $L F$ in the tricuspid valve was also significantly increased: $11.3 \pm 1.4 \%$ in $A L$ vs $5.8 \pm 0.7 \%$ in SHAM $(p<0.01)$. Labeling fractions of heart valves in SHR were not increased as compared to normal WKY. The total collagen concentration in the three heartvalves, measured by the hydroxyproline assay, did not change. The MRNA amounts of both collagen type I and III, detected by in situ hybridization, were increased in the heart valves of $A L$ and SHR animals as compared to the two control groups (SHAM and WKY). In all 3 heart valves, interstitial cells were vimentin positive, but desmin negative. A fraction of interstitial cells showed $\alpha$-smooth muscle actin (ASMA) positivity. This immunophenotype did not change during pressure overload.

Heart valves have the capacity to adapt to acute pressure overload, by means of DNA synthesis and increased collagen turnover. The increase in $L F$ in the normotensive tricuspid valve suggests a role for an additional circulating factor. A constant fraction of the interstitial heart valve cells consists of myofibroblasts.

\section{INTRODUCTION}

Heart valves are an important denominator of the function of the heart and many reports are available on hemodynamic consequences of heart 
valve disease. Morphological studies of heart valwes are restricted to descriptions of end-stages of classical heart valve diseases like rheumatic and degenerative valvular disease (Schwarz et al., 1978; Lee et al., 1983; Thiene \& Valente, 1990; Erokhina et al., 1992; Grabenwoger et al., 1992). Although it is at least conceivable that structural alterations of heart valves can affect the function of the heart, detailed studies on the structural alterations of heart valves following hemodynamic changes like pressure overload are lacking.

The experiments presented here, were designed to test the latter part of the hypothesis i.e the structure of heart valves changes during pressure overload. To test this hypothesis we analyzed dry weight, DNA synthesis and collagen mRNA amount and protein concentration during acute and chronic, stable pressure overload in analogy with described structural alterations in the heart and vessel wall during pressure overload (Schwartz et al., 1986; Abrahams et al., 1987; Olivetti et al., 1987; Doering et al., 1988; Pick et al., 1989; wan Krimpen et al., $199 \mathrm{lb})$. The possible functional consequences of structural alterations of heart valves will be adressed in subsequent studies.

A heart valve in the rat consists mainly of interstitial tissue, which is surrounded by a layer of endothelial cells. The interstitial tissue contains fibroblasts and cells that share characteristics of both fibroblasts and vascular smooth muscle cells, the so-called myofibroblasts, which might have important functions (Filip et al., 1986; Woodcock-Mitchell et al., 1988; Darby et al., 1990). Recent in vitro studies suggested two distinct phenotypes of mitral valve interstitial cells: a spindle shaped or elongated phenotype and a cuboidal or cobble stone phenotype (Johnson et al., 1987; Lester et al., 1988; Zacks et al., 1991). The same authors showed that the phenotype of these valvular interstitial cells could be modulated in culture: high serum concentrations caused a shift to the more cobble stone phenotype, while the elongated cells dominated in low serum concentration. Possible phenotypic modulation of interstitial heart valve cells in vivo have not been studied. We therefore characterized the immunophenotype of the interstitial heart valve cells, in different experimental groups, using antibodies against the cytoskeletal elements vimentin, desmin, and alpha smooth muscle actin (ASMA).

The data show that acute but not chronic pressure overload induces DNA synthesis in all three heart valves studied i.e. the mitral, tricuspid and aortic valve. The amounts of interstitial collagen types I and III mRNA, were increased in both types of hypertension. The total collagen 
concentration however, was not increased. Pressure overload did not change the immunophenotype.

\section{EXPERIMENTAL DESIGN}

Aortic ligation was used as a model for acute pressure overload, while the spontaneously hypertensive rat (SHR) was used as a model of chronic pressure overload. Mean arterial pressure in our strain of SHR gradually increases from 6 weeks of age and reaches a plateau around week 12 (Evenwel, 1982). Since we intended to use the SHR as a model for chronic and stable hypertension we choose to use animals that were 16 weeks at the end of the experiment and had been in stable hypertension for approximately one month. Normotensive SHAM and untreated WKY rats served as controls. The incorporation of 5'Bromo2 'deoxy-Uridine, given by osmotic minipump, was used as an indicator of DNA synthesis in the mitral, aortic and tricuspid valve.

Collagen type I and III mRNA amounts were detected by in situ hybridization and the collagen protein concentration was measured by the hydroxyproline assay. The immunophenotype of the interstitial heartvalve cells was determined by staining the respective valves with anti-vimentin, -desmin, and -alpha smooth muscle actin antibodies.

Mean arterial blood pressures as well as central venous pressures were obtained in a separate series of experiments. These hemodynamic parameters were obtained in conscious freely moving animals in all 4 experimental groups that were fully comparable to the animals that were used in the structural studies.

\section{MATERIALS AND METHODS}

18 Male spontaneously hypertensive rats (SHR) and 52 Wistar Kyoto (WKY) obtained from local inbred strains (University of Limburg) were used. The animals were housed in macrolon cages on sawdust in climatized rooms with a 12 hour dark-light cycle. They had free access to standard labfood and tapwater. At the start of the experiment, rats were 15 weeks of age and had a body-weight of 300-350 grams. WKY rats were randomly divided into three groups. Animals in group 1 $(n=18)$ underwent aorta-ligation (AL) 10 days before sacrifice; animals in group $2(n=17)$ were used as SHAMs and animals in group $3(n=17)$ 
served as normal controls and underwent no surgery. All experiments were performed according to institutional guidelines.

\section{Surgery}

The animals from group 1 were anaesthetized with pentobarbital $(60 \mathrm{mg} / \mathrm{kg}$ i.p.). Through a ventro-medial incision the aorta was visualized, dissected in between the renal arteries, and ligated completely. Animals in group 2 were treated equally, except for the tightening of the ligature. Animals in group 3 as well as SHR rats underwent no surgery.

Heamodynamic measurements: From each group animals were used for heamodynamic measurements ( $A L=$ SHR: $n=7$; SHAM $=$ WKY: $n=5$ ). These animals received two polyethylene catheters, one placed in the right atrium and one in the aorta, during ether anesthesia, one day before pressure measurements. The venous catheter was advanced through the vena femoralis, the aortic catheter was advanced through the femoral artery. Both catheters were tunneled subcutaneously to the neck region and closed with a plug. Three measurements in conscious freely moving animals were taken at the day of sacrifice. The catheters were connected to a pressure transducer and the data were recorded on a Astromedical desh 8 recorder. After these measurements the animals were sacrificed in deep ether anaesthesia, the ventricles were separated from the atria and the surrounding pericardium, and were weight.

DNA synthesis: 5'Bromo-2'deoxy-uridine (BrdU, Serva, Heidelberg, FRG), a thymidine analogue, which is incorporated into DNA synthesizing cells, was given to all rats via a s.c. implanted osmotic minipump $(10 \mathrm{mg} / \mathrm{ml}$ in $0.9 \% \mathrm{NaCl}$; Alzet model 2001 , ALZA, Palo Alto, Ca), at an infusion rate of $0.5 \mu \mathrm{g} / \mathrm{min}$. Minipumps were implanted during ether anaesthesia seven days before sacrifice. Data obtained with BrdU labeling correspond well with data on ${ }^{3} \mathrm{H}$-thymidine incorporation, as detected by autoradiography (Sugihara et al., 1986). The animals were sacrificed in deep ether anaesthesia and the heart and the ascending aorta were removed. During this procedure, it was noticed that the left kidney showed ischemic changes, both in colour and size, due to the aortic ligation. The $7-8$ hearts were fixed in $4 \%$ paraformaldehyde during 24 hours. Subsequently, the hearts were cut perpendicular to the annulus in an oblique plane in between the sagittal and frontal plane (figure 1). Both parts were routinely processed and embedded in paraffin. 


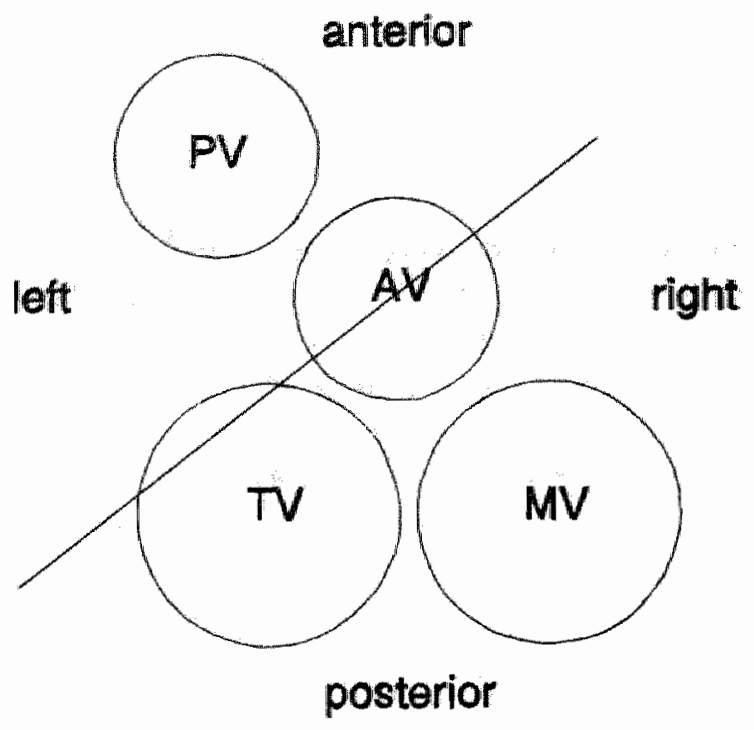

Figure 1 Basal view of the heart. / = sectioning plane; $\mathrm{AV}$ : aortic valve; MV: mitral valve; PV: pulmonary vallve; TV: tricuspid valve.

\section{Immunohistochemistry}

DNA synthesis: $4 \mu \mathrm{m}$ sections were stained immunohistochemically for BrdU. BrdU-labelled nuclei were visualized using an indirect enzyme labelled antibody technique, as described earlier (Schutte et al., 1987). Briefly, a digestion in $0.1 \mathrm{mg} / \mathrm{ml}$ pepsin (Boehringer, Mannheim, F.R.G.) in $0.1 \mathrm{~N} \mathrm{HCl}\left(30 \mathrm{~min}, 37^{\circ} \mathrm{C}\right)$, was followed by an incubation with a monoclonal anti-BrdU antibody (Eurodiagnostics, Apeldoorn, the Netherlands). Peroxidase conjugated rabbit anti-mouse IgG (Dakopatts, Glostrup, Denmark) was used as the second layer, while 3,3'Diaminobenzidine was used as chromogen. Control sections were incubated with an indifferent monoclonal antibody (Leu-2b):

After immunostaining the cumulative labeling fractions (LF, $\%=100 \times$ BrdU positive cells/total number of cells) was calculated in each heart valve (aortic valve, mitral valve and tricuspid valve) as an indicator of DNA synthesis. Stained sections were evaluated by lightmicroscopy, at a magnification of $400 x$. At least 700 nuclei per valve were counted. 
Hydroxyproline assay

After dissecting each valve from the annulus of the heart, the respective valves were pooled and the dry weight was measured $(n=4)$. The hydroxyproline content was determined as described earlier (Chiariello et al., 1986). Briefly, after hydrolysis with $6 \mathrm{~N} \mathrm{Hcl}$ the dried residues were dissolved in $\mathrm{H}_{2} \mathrm{O}$ and isopropanol $(1: 1, \mathrm{v} / \mathrm{v})$ and the hydroxyproline concentration was calculated from the absorbency reading of each sample, using a calibration curve.

\section{In Situ Hybridization}

Rat $\alpha 1$ type I procollagen cDNA ( $\alpha 1 \mathrm{R} 1$; Pst digest; 1300bp insert) and the rat $\alpha 1$ type III procollagen CDNA (RGR-5; EcoR1 digest; $1300 \mathrm{bp}$ insert) were used. $4 \mu \mathrm{m}$ Sections were cut in a RNAse free environment and treated according to the protocol described earlier (Eghbali et al., 1989). Briefly, after a short pepsin digestion the sections were hybridized overnight with random primed ${ }^{35} \mathrm{~S}$-dCTP labelled collagen I or III cDNA's.

After dehydration the sections were coated with $40^{\circ} \mathrm{C}$ Kodak NTB-2 nuclear track emulsion, and exposed for 14 days. The slides were developed in Kodak D-19 developer at $15^{\circ} \mathrm{C}$ and counterstained with haematoxylin.

\section{Immunocharacterization}

$4 \mu \mathrm{m}$ Sections were incubated with rat monoclonal anti-vimentin (Boehringer, Mannheim, FRG), mouse monoclonal anti-desmin (Organon, Oss, the Netherlands), and mouse monoclonal anti-Smooth Muscle Actin (ASMA, Sigma, St. Louis, USA). For all four antibodies a comparable indirect enzyme labelled antibody technique was used: after incubation with the primary antiserum, a peroxidase conjugated rabbitanti-mouse or swine-anti-rabbit antibody served as second layer and 3-3' Diaminobenzidine was used as chromogen. All sections were, before dehydration, counterstained with haematoxylin, during 1 minute.

\section{Statistics}

Data are presented as mean \pm sem. Comparison between the groups were performed by Wilcoxon two sample analysis. $\mathrm{P}<0.05$ was required for statistical significance. 


\section{RESULTS AND DISCUSSION}

Body weights at the onset of the experiments were comparable in all groups (300-325 gr). The ratio of heart to body weight was increased in both the aortic ligation group and the SHR group compared to the SHAM and WKY (table 1). Mean arterial blood pressures were elevated in the SHR and aortic ligation groups as compared to the controls and there was no difference in the mean arterial blood pressure in between these hypertensive groups. The central venous pressure in both hypertensive groups of animals were not different from the central venous pressure in the control groups (table 1). Aortic ligation did not increase the dry weight of the heartvalves studied. The SHR showed a significant increase in dry mitral and tricuspid valve weight compared to the WKY's (table 2).

Table 1 Mean arterial pressure (MAP), central venous pressure (CVP), and heart to body weight, in aortic ligation, SHAM, SHR and WKY. Mean \pm sem, $n=5-6$; \#: $p<0.005$, as compared to SHAM; @: $p<0.005$, as compared to WKY.
MAP $(\mathrm{mmHg})$
CVP (mmHg)
HW/BW

$\begin{array}{llrl}\text { AL } & 168.7 \pm 9.8^{*} & -1.0 \pm 0.4 & 0.38 \pm 0.02^{*} \\ \text { SHAM } & 128.7 \pm 2.7 & -1.1 \pm 0.3 & 0.31 \pm 0.02 \\ \text { SHR } & 160.9 \pm 3.5 & 0.3 \pm 0.3 & 0.35 \pm 0.01 \\ \text { WKY } & 129.0 \pm 2.7 & -1.3 \pm 0.3 & 0.29 \pm 0.01\end{array}$

\section{DNA synthesis}

The cumulative labeling fraction (LF) of interstitial cells in the three heart valves of the control groups were between $5.8 \%$ and $9.4 \%$ (figure 2 ), indicating a high amount of DNA synthesis in heart valves of adult normotensive rats. For comparison, 2 weeks cumulative labeling fractions of $2.5 \%$ have been reported for vascular smooth muscle cells in adult rats (De-Mey et al., 1991), while an 1 week cumulative labeling fraction of approximately $3 \%$ has been found in cardiac interstitial cells (van Krimpen et al., $199 \mathrm{lb}$ ). The reason for this relative high amount of DNA synthesis in heart valves is not clear. 
Table 2 Heart valve weights $(\mu g)$ in aortic ligation, SHAM, SHR, WKY animals: $M V=$ mitral valve; $A V=a o r t i c$ valve; $T V=$ tricuspid valve; $A L=$ aortic ligation. Mean \pm sem, $n=4$. ${ }^{*} p<0.001$ as compared to WKY; \# $p<0.001$ as compared to WKY; $p<0.05$ as compared to SHAM.

$\operatorname{MV}(\mu \mathrm{g}) \quad \operatorname{AV}(\mu \mathrm{g}) \quad \operatorname{TV}(\mu \mathrm{g})$

$\begin{array}{llrl}\text { AL } & 230 \pm 33 & 130 \pm 25 & 173 \pm 40 \\ \text { SHAM } & 230 \pm 47 & 83 \pm 12 & 153 \pm 38 \\ \text { SHR } & 288 \pm 17^{*} & 103 \pm 25 & 240 \pm 10^{*} \\ \text { WKY } & 133 \pm 13 & 108 \pm 10 & 135 \pm 9\end{array}$

In the $\mathrm{AL}$ group DNA synthesis was markedly increased in all three valves (figure $2 \mathrm{a}$ ). The cumulative labeling fraction in the mitral valve was $47.8 \pm 5.2 \%$ in the AL group as compared to $9.4 \pm 2.6 \%$ in the SHAM group $(p<0.01)$. The aortic valve and the tricuspid valve showed a similar pattern (figure $2 a$ ). In the AL group LF's in both the mitral valve and the aortic valve were significantly higher than in the tricuspid valve and the LF in the mitral valve was higher than in the aortic valve. No differences were detected in labeling fractions in between the valves of animals in the SHAM group.

The LF's of the three heart valves of SHR were not increased as compared to the LF's of the same valves in WKY rats (figure 2b). However, when comparing the heartvalves within SHR and within WKY, the LF's of the mitral valve were significantly higher than the LF of the tricuspid valve, while in the SHR, the LF in the aortic valve was increased also as compared to the LF in the tricuspid valve $(p<0.05)$.

\section{Collagen}

No differences were detected in collagen protein concentrations, neither between heart valves within one group, nor between comparable heart valves in different groups (table 3 ).

In situ hybridization with collagen I and III cDNA's showed increased labeling above interstitial cells in all three valves of animals in the $A L$ group as compared to the valves of other groups, indicating increased amounts of collagen type I and III mRNA (figure $4 a$ ). Comparison of in situ hybridization signals between the three valves of the $\mathrm{AL}$ animals revealed the same pattern as seen for DNA synthesis: increased signals in the mitral and aortic valve as compared to the tricuspid valve. 
Collagen type II and III mRNA hybridization signals were slightly increased above interstitial cells of SHR valves as compared to WKY

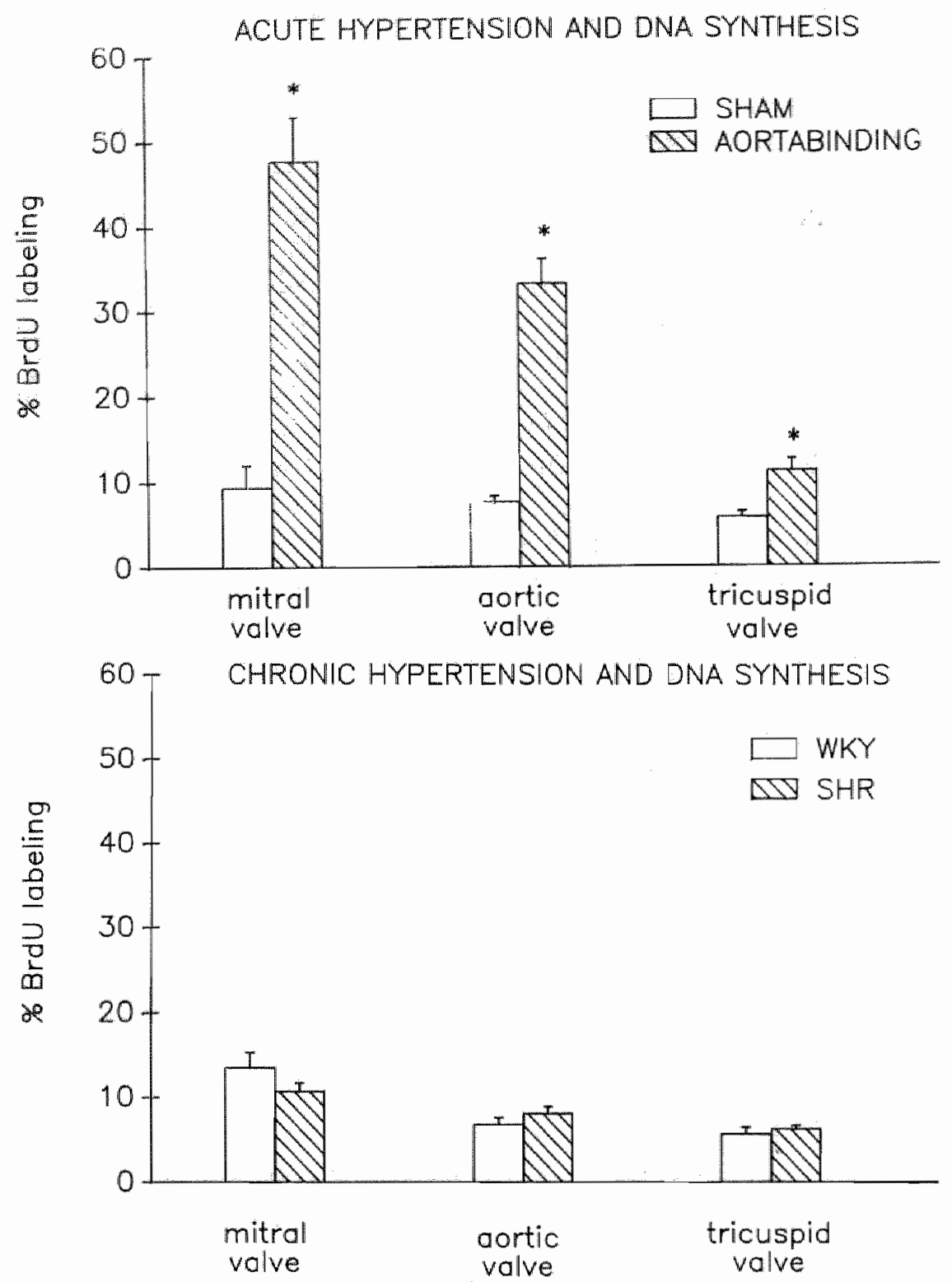

Figure 2 Histogram of DNA synthesis in A: acute hypertension and B: chronic hypertension; mean \pm sem, $\mathrm{p}<0.001 ; \mathrm{N}=8$. 

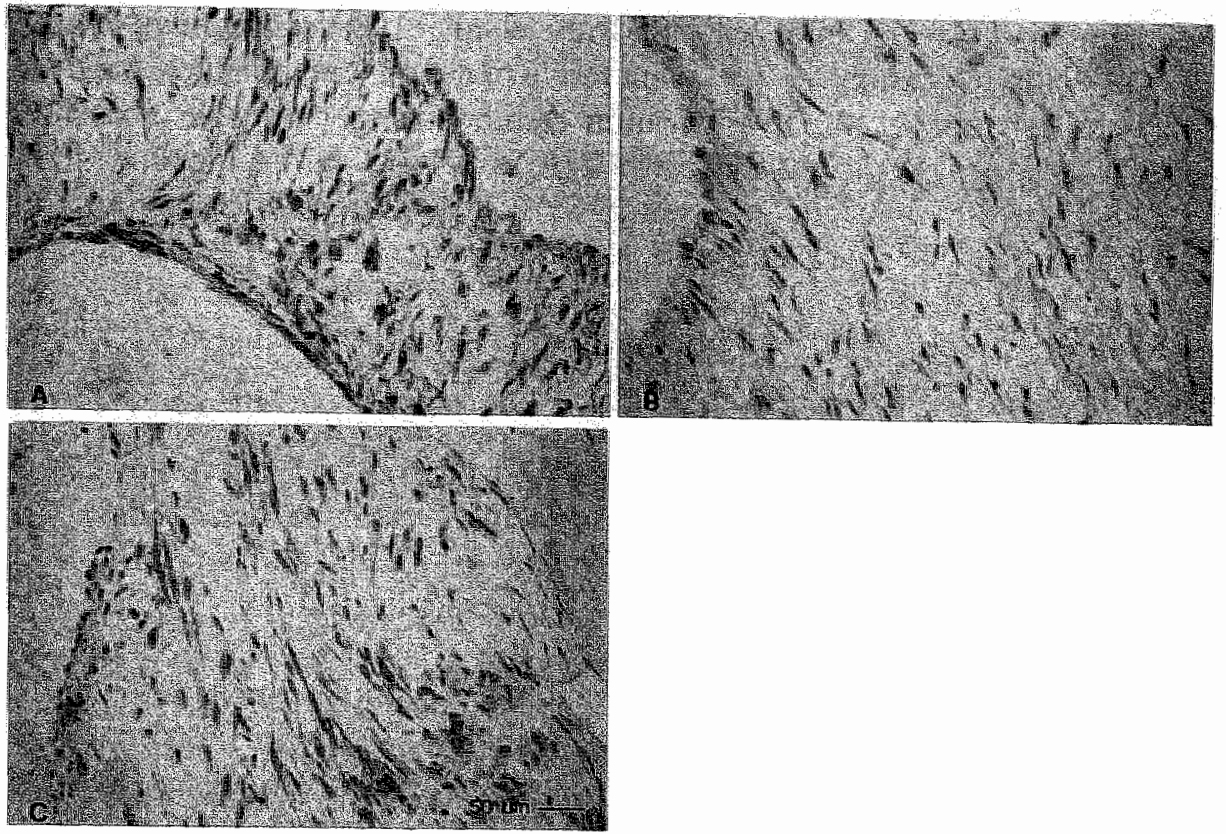

Figure 3 Photomicrograph showing phenotypic charaterization of interstitial cells of heart valves. A: Vimentin, all cells are positive; B: Desmin, all cells are negative; C: $\alpha$-smooth muscle actin, a fraction of the cells are positive.

(figure 4b). In situ hybridization signals were, however, less intense than those found in the AL animals. In both the acute and the chronic hypertension the signals were higher above the mitral and aortic valve as compared to the tricuspid valve. In hypertension, DNA synthesis is increased in vascular smooth muscle cells and in the myocardium (Gordon et al., 1986; Olivetti et al., 1987; Anversa et al., 1991). The marked increase in DNA synthesis in the aortic ligation animals follows this same pattern. However labeling fractions of interstitial heart valve cells were not different in SHR animals as compared to the LF's found in the WKY, suggesting that only an acute rise in arterial blood pressure induces DNA synthesis in heart valves. Similar findings have been reported in smooth muscle cells of large arteries, where DNA synthesis is increased in acute but not in models of chronic hypertension (Owens \& Schwartz, 1982; Olivetti et al., 1989).

Hypertension is known not only to induce DNA synthesis but also collagen synthesis in both the vascular smooth muscle (Wolinsky, 1970; Keeley \& Alatawi, 1991; Plissonier et al., 1991) and the cardiac 
interstitum (Doering et al., 1988; Pick et al., 1989; Chapman et al., 1990). Although we have no quantitative data on the collagen mRNA concentration, the in situ hybridization results strongly suggest increased amounts of collagen type I and III mRNA in aortic ligation induced hypertension, and to a lesser extent in SHR hypertension. The collagen concentration was not increased in the heart valves of the hypertensive animals (table 3 ). The induction of collagen mRNA synthesis without an increase in protein concentration indicates increased collagen turnover rates.

The experiments described in this study do not allow to distinguish which factor induces collagen and DNA synthesis in heartvalves. The bloodpressures from table 1 are in agreement with earlier studies, in which complete aortic ligation was also shown to induce a rapid increase in mean arterial blood pressure (MAP) to approximately $150 \mathrm{mmHg}$ (Baker et al., 1990), whereas in our SHR strain the MAP gradually rises from 6 weeks to reach approximately $160 \mathrm{mmHg}$, at an age of 12 weeks (Evenwel, 1982). Therefore at an age of 16 weeks, these SHR have had a constant high MAP, for approximately 1 month. Although the DNA synthesis in heart valves of SHR might have been elevated at an earlier time point, the different responses in the heart valves of SHR animals and aortic ligation animals suggests that a rise in blood pressure is not the only factor, and injury to the heart valves might contribute. Acute severe hypertension is known to induce ischemic heart injury (Silver et al, 1990), resulting in increased deposition of interstitial collagen. Also in large arteries smooth muscle DNA synthesis is increased in models of acute, but not chronic hypertension (Owens \& Schwartz, 1982; Owens \& Reidy, 1985).

Table 3. Hydroxyproline concentration in heart valves $(\mathrm{mg} / \mathrm{mg})$, in aortic ligation, SHAM, SHR, WKY animals. MV =mitral valve; $A O=$ aortic valve; $T V=$ tricuspid valve; $\mathrm{AL}=$ aortic ligation. Mean $\pm \mathrm{sem}, \mathrm{n}=4$.
MV
AV
TV

$\begin{array}{llll}\text { AL } & 0.39 \pm 0.07 & 0.22 \pm 0.03 & 0.33 \pm 0.05 \\ \text { SHAM } & 0.35 \pm 0.09 & 0.37 \pm 0.07 & 0.56 \pm 0.25 \\ \text { SHR } & 0.33 \pm 0.08 & 0.42 \pm 0.10 & 0.32 \pm 0.01 \\ \text { WKY } & 0.50 \pm 0.07 & 0.36 \pm 0.04 & 0.34 \pm 0.05\end{array}$



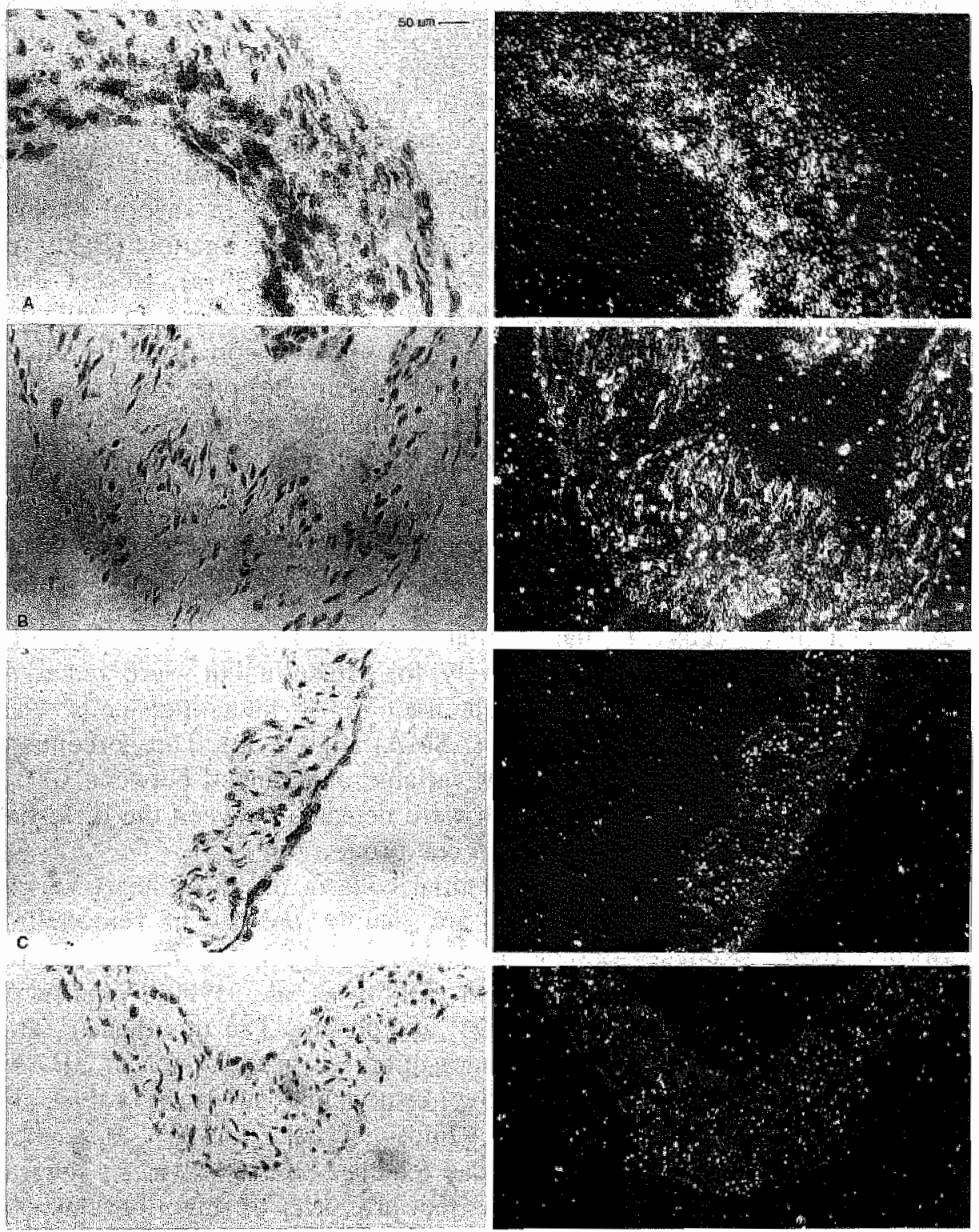

Figure 4 Darkfield photomicrograph of heart valves, after in situ hybridization with collagen type III, in acute hypertension; A: Aortic ligation; B: SHAM; and chronic hypertension; C: SHR; D: WKY 
Injury is also suggested by the relative high amount of DNA synthesis of the endothelium at the endocardial surface of the valves in our study (data not shown).

Secondly, it is conceivable to suggest an active role for circulating factors, since the "normotensive" tricuspid valve showed similar changes as the "hypertensive" mitral and aortic valves, in the $\mathrm{AL}$ rat. Several possible candidates have to be considered, including aldosterone, angiotensin II and catecholamines. Indeed, increased plasma levels of angiotensin II and catecholamines have been present in several experimental models of hypertension, including the aortic ligation (Baker et al., 1990; Brilla et al., 1991; van-Krimpen et al., 1991a). Recent data from our and other laboratories showed that the increase in collagen content in hypertrophied rat hearts during hypertension or after induction of a left ventricular wall infarction can be prevented by the administration of ACE-inhibitors. This finding suggests a role for angiotensin II in the control of interstitial collagen in the myocardium (van Krimpen et al., 1991 b; Weber \& Brilla, 1991).

\section{Immunocharacterization}

All interstitial cells in the various valves and in the different experimental groups stained positively for vimentin but were negative for desmin (figure 3a,b). A small fraction of interstitial cells was positive for $\alpha$-smooth muscle actin (ASMA) (figure 3c). The percentage of ASMA positive cells was highly variable and ranged between $0.3 \%$ and $15 \%$. No significant differences were detected between the different groups, or between the valves within one group.

Thus at least a fraction of the interstitial cells in the three heart valves are myofibroblast. Myofibroblasts are mainly present in remodeling fibrotic tissue (Rungger-Brandle \& Gabbiani, 1983), as in scar tissue and a healing myocardial infarction (Darby et al., 1990; Vracko \& Thorning, 1991; Willems et al., 1994, and chapter 3 of this thesis). The presence of myofibroblasts in the interstitium of heart valves of SHAM and WKY rats may suggest active remodeling in heart valves in hemodynamic conditions. Filip (Filip et al., 1986) described myofibroblast-like cells in the chordae tendinea of the valves in several species. Although we could show the presence of myofibroblast in interstitial heart valve cells in vivo, we could not find any evidence of phenotypic modulation as suggested in recent in vitro studies by Lester et al (Lester \& Gotlieb, 1988; Lester et al., 1988), using porcine 


\section{RLTERENCES}

Abrahams C, Janteki IS, Weber KT. Myocardial hypertrophy in Macaca fascicularis. Structural remodeling of the collagen matrix. Lab Invest (1987) $56: 676-6: 83$.

Anversa P, Fitzpatrick D, Argani S, Capasso JM. Myocyte mitotic division in the aging mammalian rat heart. Circ Res (1991) 69:1159-1164.

Baker $\mathrm{KM}$, Chernin MI, Wixson SK, Aceto JF. Renin-angiotensin system involvement in pressure-overload cardiac hypertrophy in rats. Am J Physiol (1990) 259:H324-H332.

Brilla $\mathrm{C}$, Janicki $\mathrm{JS}$, Weber $\mathrm{KT}$. Cardioreparative effects of lisinopril in rats with genetic hypertension and left ventricular hypertrophy. Circulation (1991) 83:1771-1779.

Chapman D, Weber KT, Eghbali M. Regulation of fibrillar collagen types I and III and basement membrane type IV collagen gene expression in pressure overloaded rat myocardium. Circ Res (1990) 67:787-794.

Chiariello $M$, Ambrosio $G$, Cappelli-Bigazzi $M$, Perrone-Filardi $P$, Brigante $F$, Sifola C. A biochemical method for the quantitation of myocardial scarring after experimental coronary artery occlusion. J Mol Cell Cardiol (1986) 18:283-290.

Darby $\mathbb{I}$, Skalli $O$, Gabbiani G. Alpha-smooth muscle actin is transiently expressed by myofibroblasts during experimental wound healing. Lab Invest (1990) 63:21-29.

De-Mey JG, Daemen MJ, Boonen HC, Bosman FT, Dijkstra EH, Fazzi GE, Janssen GM, Schiffers PM, Struyker-Boudier HA, Vrijdag MJ. In vivo DNA synthesis is not uniformly distributed in arterial smooth muscle of young spontaneously hypertensive rats. J Hypertension (1991) 9:695-701.

Doering CW, Jalil JE, Janicki JS, Pick R, Aghili S, Abrahams C, Weber KT. Collagen network remodeling and diastolic stiffness of the rat left ventricle with pressure overload hypertrophy. Cardiovase Res (1988) 22:686-695.

Eghbali M, Blumenfelld OO, Seifter S, Buttrick PM, Leinwand LA, Robinson TF, Zern MA, Giambrone MA. Localization of types I, III and IV collagen mRNAs in rat heart cells by in situ hybridization. J Mol Cell Cardiol (1989) 21:103-113.

Erokhina IL, Selivanova GV, Vlasova TD, Komarova NI, Emeljanova OI, Soroka VV. Ultrastructure and biosynthetic activity of polyploid atrial myocytes in patients with mitral valve disease. Acta Histochem Suppl (1992) 42:293-299.

Evenwel RT. The development of spontaneous hypertension in rats (1982) Thesis, University of Maastricht, 150 pages.

Filip DA, Radu A, Simionescu M. Interstitial cells of the heart valves possess characteristics similar to smooth muscle cells. Circ Res (1986) 59:310-320.

Gordon D, Mohai L, Schwartz S. Induction of polyploidy in cultures of neonatal rat aortic smooth muscle cells. Circ Res (1986) 59:633-644.

Grabenwoger M, Grimm M, Eybl E, Kadletz M, Havel M, Kostler P, Plenk H, Bock P. Wolner $E$. New aspects of the degeneration of bioprosthetic heart valves after long-term implantation. J Thorac Cardiovasc Surg (1992) 104:14- 
21.

Johnson CM, Hanson MN, Helgeson SC. Porcine cardiac valvular subendothelial cells in calture: cell isolation and growth characteristios. I Moll Cell Cardiol (1987) 19:1185-1193.

Keeley FW, Alatawi A. Response of aortic elastin synthesis and accumulation to developing hypertension. The inhibitory effects of colchicine. Lab Invest (1991) 64:499-508.

Lee YS, Lee FY, Lu AH, Chang CH, Chen HC, Liang KF, Chang CS. Biochemical analysis and electron microscopy of human mitral valve collagen in patients with various etiologies of mitual valve diseases. Jpn Heart J (1983) 24:529-538.

Lester WM, Gotlieb AI. In vitro repair of the wounded porcine mitral valve. Circ Res (1988) 62:833-845.

Lester W, Rosenthal A, Granton B, Gotlieb Al. Porcine mitralic valve interstitial cells in culture. Lab Invest (1988) 59:710-719.

Olivetti G, Ricci R, Amversa P. Hyperplasia of myocyte nuclei in long-term cardiac hypertrophy in rats. I Clin Invest (1987) 80: 1818-1821.

Olivetti $G$, Lagrasta $C$, Ricci $R$, Sonnenblick EH, Capasso JM, Anversa P. Long. term pressure-induced cardiac hypertrophy: capillary and mast cell proliferation. Am J Physiol (1989) 257:H1766-H1772.

Owens GK, Reidy MA. Hyperplastic growth response of vascular smooth muscle cells following induction of acute hypertension in rats by aortic coarctation. Circ Res (1985) 57:695-705.

Owens GK, Schwartz SM. Alterations in Vascular smooth muscle mass in the spontaneously hypertensive rat. Circ Res (1982) 51:280-289.

Pick $\mathbb{R}$, Janicki $\mathrm{J}$, Weber $\mathrm{KT}$. Myocardial fibrosis in nonhuman primate with pressure overload hypertrophy. Am J Pathol (1989) 135:771-781.

Plissonier D, Amichot G, Duriez M, Legagneux J, Levy BI, Michel JB. Effect of converting enzyme inhibition on the allograft-induced arterial wall injury and response. Hypert (1991) 18:1147-54.

Rungger-Brandle $\mathbb{E}$, Gabbiani $G$. The role of cytoskeletal and cytocontractile elements in pathologic processes. Am J Pathol (1983) 110:361-392.

Schutte B, Reynders MM, Bosman FT, Blijham GH. Studies with antibromodeoxyuridine antibodies: II. Simultaneous immunocylochemical detection of antigen expression and DNA synthesis by in vivo labeling of mouse intestinal mucosa. J Histochem Cytochem (1987) 35:371-374.

Schwartz S, Campbell G, Campbel』 J. Replication of smooth muscle cells in vascular disease. Circ Res (1986) 58:427-444.

Schwarz F, Flameng W, Schaper J, Hehrlein F. Correlation between myocardial structure and diastolic properties of the heart in chronic aortic valve disease: Effects of corrective surgery. Am J Cardiol (1978) 42:895-903.

Silver MA, Pick R, Brilla CG, Jalil JE, Janicki JS, Weber KT. Reactive and reparative fibrillar collagen remodeling in the hypertrophied rat left ventricle: two experimental models of myocardial fibrosis. Cardiovasc Res (1990) $24: 741-747$.

Sugihara $H$, Hattori $T$, Fukuda $M$. Immunohistochemical detection of 
bromodeoxyuridine in formalin-fixed tissues. Histochem (1986) 85:193-195.

Thiene $G$, Valente $M$. Degenerative, non-atherosclerotic cardiovascular disease in the elderly: a clinico-pathological survey. Aging Milano (1990) 2:23 1-244.

van-Krimpen $C$, Schoemaker RG, Cleutjens JP, Smits JF, Struyker-Boudier HA, Bosman FT, Daemen MI. Angiotensin I converting enzyme inhibitors and cardiac remodeling. Basic Res Cardiol (1991a) 86 Suppl 1:149-155.

van Krimpen C, Smits JFM, Cleutjens JPM, Debets JJM, Schoenmaker RG, Struyker Boudier HAJ, Bosman FT, Daemen MJAP. DNA synthesis in the non-infarcted cardiac interstitium after left coronary artery ligation in the rat: effects of Captopril. J Mol Cell Cardiol (1991b) 23:1245-1253.

Vracko $R$, Thorning D. Contractile cells in rat myocardial scar tissue. Lab Invest (1991) 65:214-227.

Weber KT, Brilla CG. Pathological hypertrophy and cardiac interstitium. Fibrosis and renin-angiotensin-aldosterone system. Circulation (1991) 83:1849-1865.

Willems IEMG, Havenith MG, De Mey JGR, Daemen MJAP. Alpha smooth muscle actin positive cells in healing human myocardial scars. Am J Pathol (1994) 145:868-875.

Wolinsky H. Response of the rat aortic media to hypertension. Circ Res (1970) 26:507-522.

Woodcock-Mitchell J, Mitchell JJ, Low RB, Kieny M, Sengel P, Rubbia L, Skalli O, Jackson B, Gabbiani G. Alpha-smooth muscle actin is transiently expressed in embryonic rat cardiac and skeletal muscles. Differentiation (1988) 39:161-166.

Zacks S, Rosenthal A, Granton B, Havenith M, Opas M, Gotlieb AI. Characterization of Cobblestone mitral valve interstitial cells. Arch Pathol Lab Med (1991) 115:774-779. 
CHAPTER 7

\section{GENERAL DISCUSSION}




\section{GENERAL DISCUSSION}

Reflections and future directions.

The first goal of this thesis was to describe changes in the interstitium in left ventricular hypertrophy (LVH) and myocardial infarction in humans. The studies of this thesis demonstrate that the interstitium in the hypertrophied human myocardium can remodel. Differences in the remodeling process between different forms of left ventricular hypertrophy are documented: the interstitium of hearts with LVH due to hypertension and post myocardial infarction enholds a larger amount of collagen compared to the interstitium of hearts with LVH as a result of other causes. This difference in structural alterations had already been suggested by experimental studies (Doering et al., 1988; Michel et al., 1988; Pick et al., 1989; Contard et al., 1991). The concordance of the data of the present, human, study validates the use of rat model experiments. In experimental studies the increase in interstitial collagen was accompanied by impaired cardiac function (Schoemaker et al., 1991; van Krimpen et al., 1991). Clinical data also show a worse prognosis in patients with LVH due to pressure overload or post myocardial infarction. Combining experimental data with the data of this thesis results in circumstantial evidence for the association of interstitial collagen content and prognosis of LVH. To actually prove this association further studies are necessary. A possible study might be directed to the interstitial collagen content in human myocardium with congestive heart failure (CHF). A flaw for such a study, is that the only material present, probably will be autopsy material. Studies with this material, as in the present thesis, will mainly be concentrated on the protein level as the detection of mRNA will be variably effected by postmortem autolysis. Endomyocardial biopsies therefore, seem to be the material of choice.

In chapter 1 the hypothesis is forwarded that in myocardial infarction the woundhealing itself is important in haemodynamic function and prognosis. The studies presented in this thesis demonstrates that interstitial remodeling in human myocardial infarcts not only entails the removal of necrotic tissue but also an active process. This metabolically active process has general characteristics, also present in dermal woundhealing: tenascin and fibronectin are transiently expressed early after myocardial infarction. Collagen formation occurs later during woundhealing. These similarities with dermal woundhealing might suggest that dermal woundhealing is a good experimental model for 
myocardial woundhealing. Nevertheless, one has to keep in mind that the latter also has tissue specific characteristics of which the sustained presence of myofibroblasts is one aspect. These myofibroblasts give the scar tissue the possibility to contract. The absence of myofibroblasts in myocardial scar tissue might result in ventricular aneurysm and subsequently lead to low cardiac output and even CHF. To investigate this assumption, the $\alpha$-smooth muscle actin amount should be quantified in ventricular aneurysms compared to non-aneurysmatic transmural infarctions.

Another tissue specific characteristic of the myocardium is the presence of so-called hibernating myocardium. The studies presented in this thesis demonstrate the existence of interstitial remodeling in hibernating myocardium. The remodeling does resemble myocardial woundhealing at least with respect to the expression of tenascin. The sustained presence of tenascin in the interstitium of hibernating myocardium, however is different from postinfarct woundhealing. This might suggest the existence of ongoing extracellular matrix remodeling. The absence of fibronectin in the interstitium of hibernating myocardium indicates a possible difference in function between tenascin and fibronectin. Recent studies suggested that the extracellular matrix remodeling in hibernating myocardium might be responsible for the "hibernating" phenotype of the cardiomyocytes (Ausma et al., 1995). Insights in the regulation of this remodeling could, therefore, lead to therapeutic interventions which may change the phenotype of the cardiomyocytes.

The second goal of this thesis was to identify possible regulators of the remodeling of the interstitium in the myocardium.

In this thesis TGF- $\beta$ was found during human myocardial woundhealing. TGF- $B$, normally present in cardiomyocytes, disappeared 6 hours postinfarction. Four to six days postinfarction $T G F-\beta$ re-appeared in the infarct, present in myofibroblasts. The expression of tenascin coincided with TGF-B. In the hibernating myocardium TGF-B was also detectable, again coinciding with tenascin. In experimental studies $T G F-\beta$ is proposed as a regulator of fibrosis, is also claimed to induces tenascin and fibronectin expression (Walker et al., 1994). In dermal woundhealing TGF-B modulates myofibroblasts phenotype (Bachem et al., 1993; Desmouliere et al., 1993; Ronnov-Jessen \& Petersen, 1993). Again, combining experimental data with the data presented in this thesis strongly suggests a regulatory role for TGF- $\beta$ in human myocardial woundhealing. Local application of TGF-B might be 
beneficiall during myocardial woundhealing. What type of TGF-13 should be applied, however, remains to be elucidated. The present study does not indicate what type of TGF-B might be important during woundhealing, as the antibody used, recognized TGF-B 1,2 and 3 . The TGF-B receptor responsible for transducing the cytokine action during woundhealing, still is unknown. Therefore, future studies are necessary before $T G F-B$ and its receptors can be regarded as of possible clinical and pharmacological importance.

Pharmacological agents that are already present, are of little use in prevention of CHF. The only drug, so far, that appears to have a beneficial effect on the longevity is angiotensin converting enzyme inhibitor (ACEi). The exact pathway leading to this beneficial effect is unclear. One action of $\mathrm{ACEi}$ is inhibition of the production of angiotensin II. This protein is associated with increased collagen content in experimental studies regarding rat myocardium (van Krimpen et al., 1991). In the present thesis rat heart valwes, solely consisting of interstitium, were used as a model for structural alterations in a reninangiotensin-aldosterone-system (RAAS) dependent pressure overload. DNA synthesis was increased in the heart valves of both the left and right site of the heart. Collagen mRNA levels were increased. These structural alterations are in keeping with those, elsewhere in the heart. The collagen content in the heart valves, however was not increased, indicating an increased collagen turn-over. This difference in remodeling indicates that the heart valves are not an ideal model of interstitial remodeling in general, but the data demonstrate that heart valve are not inert. The remodeling could lead to heartvalve disease and subsequent increase the effects of the pressure overload. The data also suggest a role for circulating factor, in the remodeling. As this model is RAAS dependent, future studies will be directed to this area.

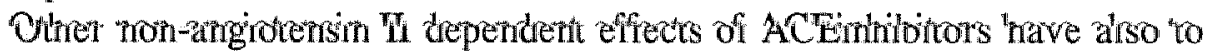
be considered. ACE is also active as kinase $\Pi_{\text {, which acts as an }}$ inhibitor of bradykinin. Bradykinin is a protein important in the degradation of collagen. ACE therefore, also is an inhibitor of collagen degradation. The beneficial effect of ACEinhibitors could subsequently also be due to an effect on collagen degradation.

Not only in LVH due to pressure overload $\mathrm{ACEl}$ is beneficial. Recent studies demonstrated a beneficial effect of early treatment of ACEi after human myocardial infarction (ISIS-4, 1995). This beneficial effect might not only be a result of regulation of remodeling in the non-infarcted myocardium, but also in the infarcted area. Since experimental studies 
have shown that angiotensin induces the expression of TGF-B, fibronectin and collagen, it is attractive to speculate on a role for angiotensin II and ACEi in infarct remodeling. 


\section{REFERENCES}

Ausma IMS, Schaart G, Thone F, Shivalkar B, Flameng $W$, Depre $C$, Vanoverschelde $J-L$, Ramaekers $F$, Borgers $M$. Chromic ischemic viable myocardium in man: aspects of dedifferentiation. Cardiovasc Pathol (1995) 4:29-37.

Bachem MG, Sell KM, Melchior $R$, Kropf $J$, Eller $T$, Gressner AM. Tumor necrosis factor alpha (TNF-alhpa) and transforming growth factor beta- $\mathbb{1}$ (TGF-beta-1) stimulate fibronectin synthesis and the transdifferentiation of fatstoring cells in the rat liver into myofibroblasts. Virchows Arch B Cell Pathol (1993) 63:123-130.

Contard F, Koteliansky V, Marotte F, Dubus I Rappaport L, Samuel JL. Specific alterations in the distribution of extracellular matrix components within rat myocardium during the development of pressure overload. Lab Invest (1991) 64:65-75.

Desmouliere A, Geinoz A, Gabbiani F, Gabbiani $G$. Transforming growth factorbeta 1 induces aipha-smooth muscle actin expression in granulation tissue myofibroblasts and in quiescent and growing cultured fibroblasts. J Cell Biol (1993) 122:103-111.

Doering CW, Jalil JE, Janicki JS, Pick R, Aghili S, Abrahams C, Weber KT. Collagen network remodeling and diastolic stiffness of the rat left ventricle with pressure overload hypertrophy. Cardiovasc Res (1988) 22:686-695.

ISIS-4. ISIS-4: A randomised factorial trial assessing early oral captopril, oral mononitrate, and intravenous magnesium sulphate in 58050 patients with suspected acute myocardial infarction. Lancet (1995) 345:669-685.

Michel JB, Lattion AL, Salzmann JL, de Lourdes Cerol M, Philippe M, Camelleri $J P$, Corvol P. Hormonal and cardiac effects of converting enzyme inhibition in rat myocardial infarction. Circ Res (1988) 62:641-650.

Pick R, Janicki JS, Weber KT. Myocardial fibrosis in nonhuman primate with pressure overload hypertrophy. Am J Pathol (1989) 135:771-781.

Ronnov-Jessen L, Petersen OW. Induction of alpha-smooth muscle actin by transforming growth factor-beta 1 in quiescent human breast gland fibroblasts. Implications for myofibroblast generation in breast neoplasia. Lab Invest (1993) 68:696-707.

Schoemaker RG, Debets JJM, Struyker-Boudier HAJ, Smits JFM. Delayed but not immediate captopril therapy improves cardiac function in conscious rats. J Moll Cell Cardiol (1991) 23:187-197.

van Krimpen C, Smits JFM, Cleutjens JPM, Debets JJM, Schoenmaker RG, Struyker Boudier HAJ, Bosman FT, Daemen MJAP. DNA synthesis in the non-infarcted cardiac interstitium after left coronary artery ligation in the rat: effects of Captopril. J Mol Cell Cardiol (1991) 23:1245-1253.

Walker RA, Dearing SJ, Gallacher B. Relationship of transforming growth factor $\beta 1$ to extracellular matrix and stromal infiltrates in invasive breast carcinoma. Br J Cancer (1994) 69:1160-1165. 


\section{SUMMARY}

The prognosis of patient with left ventricular hypertropliy (LVH), largely depends the occurrence of congestive heart failure. The occurrence of heart failure itself is the result of the primary disease, Progression to congestive heart failure, therefore will occur more often and earlier in time in patients with $\mathrm{LVH}$ as a result of hypertension or a myocardial infarction compared to patients with LVH as a result of valvular regurgitation. In experimental studies it has been demonstrated that the structural alterations in the myocardium as a result of LVH are different in the different types of LVH. This diversity in structural alterations may explain the difference in prognosis. Human studies, however, are limited. In the present thesis structural alterations in human myocardium have been studied.

In chapter 2 the changes of interstitial collagen in the human non infarcted interventricular septum after a myocardial infarction as well as in hypertrophic human hearts with or without hypertension are discussed. The collagen amount was determined with the Sirius Red morphometry technique.

The collagen amount was significantly increased in the septum of both the patients with a myocardial infarction as well as the patients with systemic hypertension compared to the patients without LVH. Interesting, however, is the finding that the interstitial collagen content of patients with idiopathic LVH was comparable to the interstitial collagen content of patients without LVH.

The data suggest that the appearance of excessive collagen is not mediated by cardiac hypertrophy per se, but that the underlying cause, infarction or hypertension, is the significant factor.

After myocardial infarction not only the remodeling of the viable myocardium is present in the heart, but also ischemic myocardium with subsequent woundhealing. The woundhealing itself is also essential to the function of the heart and therefore to the prognosis of the patient. Studies detailing human myocardial woundhealing are rare, if present at all. Other tissues however have been studied. In both experimental and human dermal wounding myofibroblasts are transiently present during woundhealing. Tenascin and fibronectin are two matrix proteins known to be present in early experimental woundhealing, and are suggested to function as a meshwork essential to the organization of other matrix proteins such as collagen. TGF- $\beta$ is suggested to be an important mediator in fibrosis and tissue repair. It is also the only cytokine, 
presently known to induce the presence of myofibroblasts in experimental dermal woundhealing.

In chapter 3 to 5 studies detailing human myocardial woundhealing and its possible regulation are described. The presence of myofibroblasts and the matrix proteins tenascin and fibronectin are highlighted in chapter 3 and 4 . The distribution of transforming growth factor-B (TGF-B) is studied in chapter 5 . In these chapters the myocardium of a group of patients with a myocardial infarction with a different postinfarction time (6 hours till 17 years) was analyzed. The material was immunohistochemically treated with antibodies directed against $\alpha$ smooth muscle actin (ASMA), a well known marker for myofibroblasts; anti-vimentin and desmin antibodies to further analyze the phenotype of myofibroblasts; antibodies directed against both matrix proteins tenascin and fibronectin, and anti-TGF- $\beta$ antibody.

The data presented in these chapters led to the following concept of human myocardial woundhealing.

TGF-B, normally present in cardiomyocytes, disappeared 6 hours postinfarction. While fibronectin was already present in the ischemic cardiomyocytes within 1 day, tenascin was found 4 to 6 days postinfarction. The presence of tenascin coincided with that of myofibroblasts, containing TGF- $\mathrm{B}$. Two weeks post myocardial infarction tenascin expression had shifted from the border of the infarction to the centre. At this time the myofibroblasts demonstrated a preferential alignment parallel to the surrounding myocardium in patchy infarctions and parallel to the epiand endocardium in transmural infarctions. The myofibroblasts remained present parallel to the surrounding tissue, while tenascin and fibronectin expression had disappeared $>4$ weeks postinfarction.

Another interesting observation was the persistent presence of tenascin but not fibronectin surrounding hibernating cardiomyocytes, present in the non-infarcted subendocardium. TGF- $\beta$ was present in the cytoplasm of these hibernating cardiomyocytes.

In conclusion, myofibroblasts are present in human myocardial wound healing and remain present in mature scar tissue, in a preferential alignment. This may be the result of the continuous mechanical stress caused by the ongoing contraction and relaxation of the surrounding viable myocardium. The coexpression of TGF-B and ASMA in myofibroblasts at least supports the suggestion that TGF- $B$ is involved the regulation of myofibroblast phenotype expression. Tenascin and fibronectin are transiently present during early myocardial woundhealing.

In addition, tenascin but not fibronectin is present surrounding 
hibernating cardiomyocytes, pointing to a functional difference between these proteins. The coexpression of TGF-B and tenascin in both myocardial woundhealing and hibernating myocardium might suggest a regulatory role for TGF- $B$ in early matrix production as well.

Another potent regulatory protein is angiotensin II. In clinical studies, the beneficial effect on longevity of Angiotensin I Converting Enzyme inhibitor therapy has been demonstrated. In chapter 6 a study was described in which rat heart valves, solely consisting of interstitium, were used as a model for structural alterations in a renin-angiotensinaldosterone-system (RAAS) dependent pressure overload. DNA synthesis, collagen mRNA and protein concentrations were measured in heart valves of Wistar Kyoto rats with acute left ventricular pressure overload, created by intra-renal aortic ligation (AL) as well as in heart valves of age-matched spontaneously hypertensive rats (SHR), a model of chronic hypertension.

The cumulative 5'Bromo-2'deoxy-Uridine labeling fraction (LF), an indication for DNA synthesis, in the mitral, aortic and tricuspid valve was evaluated. All valves of AL animals had a significant increase in LF compared to sham animals. Labeling fractions of heart valves in SHR were not increased as compared to normal WKY.

The total collagen concentration in the three heartvalves did not change. The mRNA amounts of both collagen type I and III, detected by in situ hybridization, were increased in the heart valves of AL and SHR animals as compared to the two control groups (SHAM and WKY). In all 3 heart valves, interstitial cells were vimentin positive, but desmin negative. A fraction of interstitial cells showed ASMA positivity. This immunophenotype did not change during pressure overload.

Thus, heart valves have the capacity to adapt to acute pressure overload, by means of DNA synthesis and increased collagen production. This structural alterations are in keeping with the alterations elsewhere in the heart. The absence of increased collagen content, however, suggests an increased collagen turnover. This difference in remodeling indicates that heartvalves are not an ideal model for the cardiac interstitium. The remodeling, however, could lead to heartvalve disease and subsequent increase the effects of pressure overload. The increase in LF in the normotensive tricuspid valve also suggests a role for an additional circulating factor. 


\section{SAMENVATTING}

De progniose van patiënten met myocardhypertrofie wordt grotendeels bepaald door het al of niet ontstaan van hartfalen. Dit falen van de linker ventrikel wordt medebepaald door het onderliggende hartiijden. Zo wordt dit hartfalen frequenter en op een eerder tijdstip waargenomen bij patiënten waarbij de linker ventrikel hypertrofie ontstaan is na een langdurig bestaande systemische hypertensie of een myocardinfarct, dan bij patiënten waarbij de hypertrofie ontstaat bij een insufficiëntie van de aorta of mitralis kleppen.

De oorzaken van dit verschil in prognose zijn onduidelijk. Variaties in de opbouw en samenstelling van de hartspier zou een van de verklaringen kunnen zijn. Deze variaties zijn in dierexperimenteel onderzoek aangetroffen en beschreven. Het betreft hier met name veranderingen in de samenstelling en hoeveelheid van het interstitium van het myocard. Over de aard van en de veranderingen die optreden in de samenstelling en bestanddelen van het interstitium van het myocard bij de mens is nog slechts weinig bekend en vormt het onderwerp van dit proefschrift.

In hoofdstuk 2 worden veranderingen in de hoeveelheid collageen in het interstitium van het humane hart beschreven. Onderzocht werd materiaal van patiënten met een linker ventrikel hypertrofie bij een myocardinfarct, een groep patiënten met myocardhypertrofie bij hypertensie, en een groep met idiopathische $\mathrm{LVH}$ en vergeleken met een controle groep zonder myocard hypertrofie. De hoeveelheid collageen in het myocard van het interventriculaire septum werd geanalyseerd middels de Sirius Rood morfometrie techniek.

De hoeveelheid collageen in de beide groepen patiënten met LVH op basis van een myocardinfarct en op basis van systemische hypertensie was significant hoger dan in de groep patiënten zonder hartafwijkingen. Verrassend evenwel was dat de hoeveelheid interstitiëel collageen in de groep patiënten met idiopathische myocardhypertrofie niet verschilde van die waargenomen in de groep zonder hartafwijkingen.

Dit suggereert dat de aard van het onderliggende lijden en niet de aanwezigheid van LVH alleen, de toename in interstitiëel collageen in het hypertrofe myocard verklaart.

$\mathrm{Na}$ een myocardinfarct is niet alleen het interstitiële collageen van belang in het verdere beloop, ook de wondgenezing zelf is essentieel voor de prognose van de patiënt. De wondgenezing in het hart is nauwelijks beschreven. Wel zijn er experimentele studies aangaande 
ander weefsels en aspecten van wondgenezing. $Z 0$ is van de wondgenezing in de huid bekend dat myofibroblasten tijdelijk aanwazig zijn. Ook zijn extracellulaire matrix eiwitten beschreven zoals tenascine en fibronectine. Beide eiwitten worden verondersteld te dienen als tijdelijke matrix waardoor ander eiwitten zoals collageen, zich kunnen organiseren. Als regulerend eiwit; wordt TGF- $\$ 3$ gepostuleerd. Dit cytokine induceert fibrose formatie, maar is ook bekend als regulator van de expressie van het myofibroblastaire fenotype, zoals beschreven in experimentele wondgenezing in de huid.

In de hoofdstukken 3 tot en met 5 wordt de wondgenezing in het humane hart en de mogelijke regulatie hiervan beschreven.

Hoofdstuk 3 en 4 beschrijven studies naar de aanwezigheid van myofibroblasten en matrixeiwitten zoals tenascine en fibronectine in het myocard infarct. Hoofdstuk 5 beschrijft een onderzoek naar de aanwezigheid van transforming growth factor- $\beta$ (TGF- $\beta$ ), een cytokine van belang zo niet essentieel in de regulatie van de wondgenezing.

In al deze hoofdstukken werd het myocard van een groep patiënten bestudeerd waarbij het myocard infarct op verschillende tijdstippen voor het overlijden was ontstaan. Deze varieerden tussen de 6 uur en de 17 jaar. Het materiaal werd immunohistochemisch bewerkt met verschillend antilichamen. Ter typering van de myofibroblasten werden anti- $\alpha$-gladde spier cel actine (ASMA), anti-desmine en anti-vimentine gebruikt. De overige antilichamen waren gericht tegen tenascine en fibronectine en TGF-B.

De in deze hoofdstukken beschreven bevindingen hebben geleid tot het volgende concept van wondgenezing in het humane hart.

TGF $-\beta$ is normaal aanwezig in cardiomyocyten, maar kan 6 uur na het infarct niet meer worden aangetoond. 12 uur na het ontstaan van het infarct is fibronectine aanwezig, dit in tegenstelling tot tenascine dat pas na 4 tot 6 dagen wordt aangetroffen. Tegelijk met de aanwezigheid van tenascine kunnen ook myofibroblasten worden aangetoond. Deze myofibroblasten bevatten TGF-B, dat daarmee opnieuw verschijnt in de wondgenezing. Circa twee weken na het infarct kan tenascine voorheen uitsluitend gelokaliseerd aan de rand wan het infarct ook in het infarctcentrum worden aangetroffen. Tegelijk vindt er een verschuiving plaats van de myofibroblasten, die nu met hun lange as parallel aan het ongevende weefsel gelokaliseerd zijn. Deze parallelle rangschikking behouden ze tot zelfs 17 jaar na het infarct. Tenascine en fibronectine zijn 4 weken na het myocardinfarct niet meer te detecteren.

Een volgend opvallend feit was de aanwezigheid van tenascine en de afwezigheid van fibronectine rond hibernerende cardiomyocyten 
aanwezig in het subendocardium. Voorts werd in het cytoplasma van deze cardiomyocyten TGF- 3 aangetroffen.

Een van de meest opvallende bevindingen was de aanwezigheid van myofibroblasten in de wondgenezing na een myocardinfarct. Opmerkelijk was met name dat deze cellen aanwezig blijwen in matuur litteken weefsel en zelfs 17 jaar na een myocardinfarct nog kunnen worden aangetoond. Een verklaring hiervoor zou kunnen zijn de voortdurend aanwezige mechanische stress in het hart zowel tijdens de contractie alls de relaxatie van het hart. Dat in het cytoplasma van myofibroblasten TGF- $\beta$ kan worden aangetoond steunt de veronderstelling dat het cytokine TGF-13 een belangrijke rol speelt in de regulatie van de expressie van het myofibroblastaire fenotype.

De aanwezigheid van tenascine en fibronectine in de wondgenezing na een myocardinfarct is van voorbijgaande aard. De aanwezigheid van tenascine en niet fibronectine rond hibernerende cardiomyocyten kan een aanwijzing zijn voor een mogelijk functioneel verschil tussen beide eiwitten. Het vrijwel gelijktijdig verschijnen van het cytokine TGF-B en het matrixeiwit tenascine in de wondgenezing en de coexpressie van beide in en rond het hibernerend myocard suggereert dat dit cytokine een regulerende rol speelt in de expressie van vroege matrix eiwitten.

Een ander, bekend, regulerend eiwit is angiotensine II. In meerdere klinische studies is aangetoond dat Angiotensine I Converting Enzyme inhibitor (ACEi) therapie een gunstig effect heeft op de overleving van de patiënt met LVH na myocard infarct of hypertensie. In hoofdstuk 6 word een studie beschreven waarbij de hart kleppen van de rat zijn bestudeerd. Deze kleppen, die volledig uit interstitium bestaan, dienden als model voor structurele veranderingen in een Renine-AngiotensineAldosterone-systeem afhankelijk druk overbelasting van de linker ventrikel. DNA synthese, mRNA van collageen I en III en eiwit concentraties zijn bepaald in hartkleppen van Wistar Kyoto ratten (WKY) met een acute druk overbelasting van de linker ventrikel door een ligatie van de abdominale aorta (AL). Ook werden de kleppen van even oude spontaan hypertensieve ratten (SHR) geanalyseerd als een model voor chronische hypertensie.

De 5'Bromo-2'desoxy-Uridine cumulatieve labelings index (LI), een maat voor DNA synthese, werd bepaald in de mitralis, aorta klep en tricuspidalis. Alle hartkleppen van de $\mathrm{AL}$ groep toonden een significant hogere LI vergeleken met de SHAM geopereerde dieren. De labelings index van hartkleppen van de SHR groep was vergelijkbaar met die van normale WKY's. 
De totale hoeveelheid collageen bleef constant in alle hartkleppen. Wel werd er een toename gezien aan mRNA collageen I en III in de hartkleppen van de AL groep en van de SHR groep.

De interstitiële cellen in de drie hartkleppen bevatten vimentine. Desmine werd niet aangetroffen. Een constant deel van de cellen bevatte voorts $\alpha$-gladde spiercel actine ten teken van myofibroblastaire differentiatie.

Dus, hartkleppen bezitten de mogelijkheid zich aan te passen aan acute druk overbelasting, door DNA synthese en een toename in collageen produktie. Deze structurele veranderingen zijn overeenkomstig die, elders in het hart. Een duidelijk verschil is echter de afwezigheid van collageen hoeveelheid toename, hetgeen een verhoogde collageen turnover suggereert. Dit duidelijke verschil toont aan dat hartkleppen geen ideaal model zijn voor het totale interstitium in het hart, maar het toont tevens aan dat hartkleppen actief metaboliserende structuren zijn. De structurele veranderingen in hartkleppen kunnen aanleiding geven tot hartklep afwijkingen, die opnieuw de effecten van de drukoverbelasting versterken: een vicieuze cirkel. De toename van LI in the normotensieve tricuspidalis suggereert voorts het bestaan van een circulerende factor van belang bij de regulatie deze structurele veranderingen. 


\section{CURRICULUM VITAE}

Ingrid E.M.G. Willems

6 april 1967

1979-1985

1985-1991

1991-1995
Geboren te Brunssum

VWO. Rombouts College te Brunssum

Studie Geneeskunde aan de Rijksuniversiteit Limburg te Maastricht

Aanstelling als Assistent Geneeskunde in Opleiding tot Patholoog, afd Pathologie, Academisch Ziekenhuis Maastricht (Prof. dr. JW Arends) 
interstitial heart valve cells.

This is the first study investigating possible alterations in the structure of heart valves in vivo during pressure overload. The data presented show that heart valves are not inert structures, but have the capacity to adapt to altered hemodynamic conditions. In analogy to structure-function analyses in the heart and vascular smooth muscle, it is tempting to suggest that an altered structure of the heart valve influences its function, which may lead to an altered heart function. 